Historic, Archive Document

Do not assume content reflects current scientific knowledge, policies, or practices. 


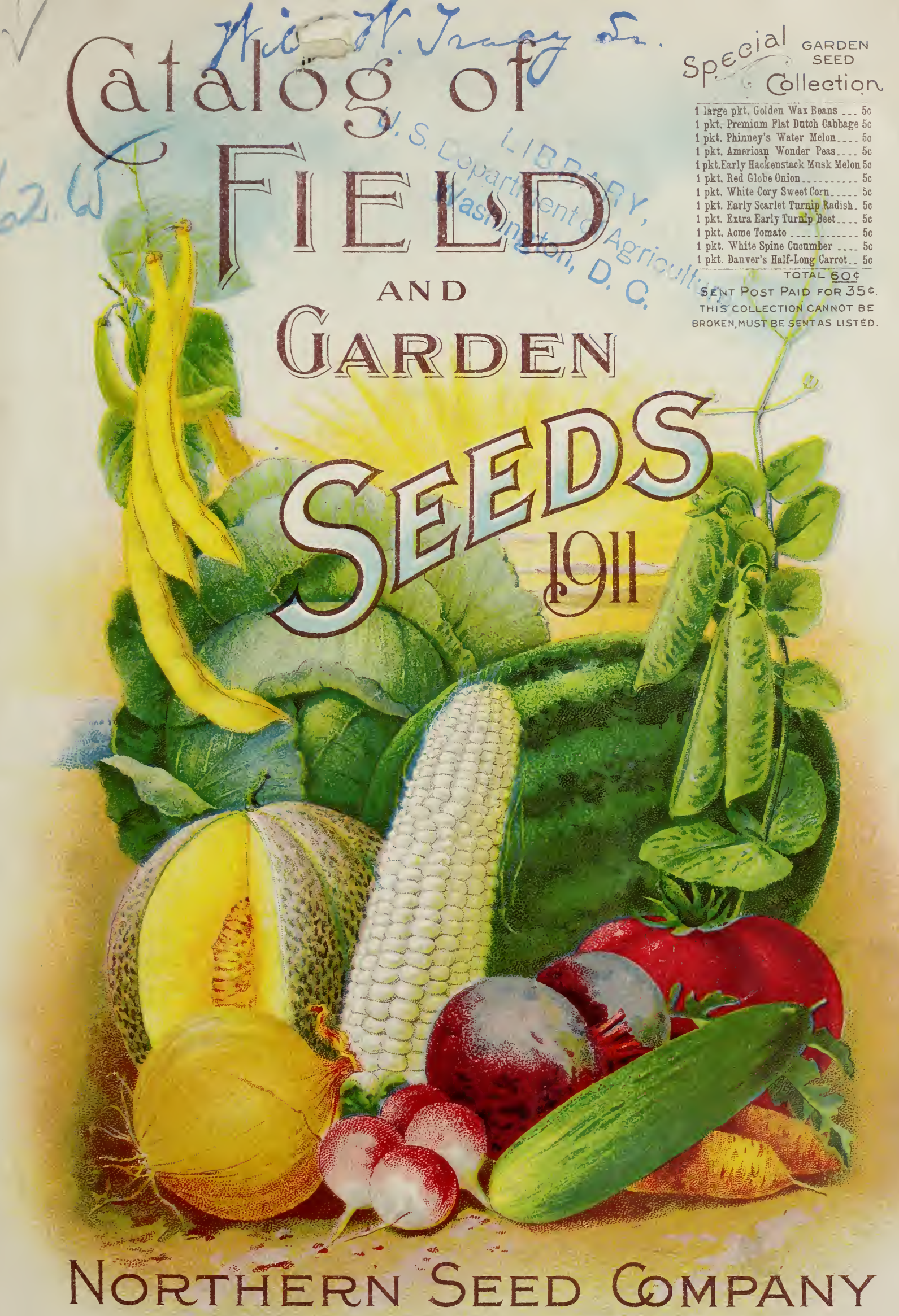

111 LARGEST GROWERS OF SEEDS IN THE NORTHWEST. VALLEY CITY, N.D. 
The three letters below will convince you whether or not we are reliable to handle your money and furnish your seeds.

The policy of our business has been to give the very best of satisfaction backed up by absolutely honest business principles and satisfactory capital to so conduct our business. Note the following letters:

DR. L. S. PLATOU, PRESIDENT LOUIS NOLTIMIER, VICE-PRESIDENT

\section{BANK OF VALLEY CITY \\ Capital $\$ 35,000$}

JAS. J. EARLEY, CASHIER

WALTER COOP, ASST, CASHIER

To Whom It May Concern :

We have pleasure in stating that the Northern Seed Company has been in business in this city for the past five years, and that we have always found them trustworthy and reliable. Their invariable policy has been and is to deal fairly with all customers, and no one need hesitate to do business with them in their line.

Yours very truly,
Bank of Valley City,

Bank of Valley City,

A. H. GRAY, President $\quad$ C. J. LEE, Vice-Pres. JAMES GRADY, CASHier 5364

THE AMERICAN NATIONAL BANK

OF YALLEY CITY, N. D.

ESTABLISHED 1899

Capital \$50,000.00. Surplus \& Profits $\$ 50,000.00$.

Real Estate Loans Negotiated. Special Attention Given to Collections

Valley City, North Dakota

Sept. $27, ' 10$

Farmers and Gardeners.

Gentlemen :- We have known Mr. E. S. DeLancey, Manager of the Northern Seed Company, for ten years or more, He has built this Company up to one of the best seed concerns in the Northwest. He is always on the lookout for the best varieties for our climate. His seeds are fresh and well grown, he superintending the raising of them himself, and he is thoroughly posted and up-to-date in his work

The Company has grown to be one of the industries of Valley City and is on a sound financial basis. The writer has tried and tested the Northern Seed Company's seeds and found them superior to anything he has been able to get elsewhere. The winter wheat I got from this Company and planted in fall of 1908 produced this season almost three times as much per acre as the blue stem seeded along side. I can fully recommend this Company to anyone wishing to procure good and fresh seeds, and varieties that will be best to withstand our climate.

herman Winterer, Prestdent, ARTHUR MILLER, VICE-PRHSIDENT

\section{Very respectfully}

A. H. GRAY, President.

JAMES GRADY, Cashier.

JOHN TRACY, CASHIER A. J. HENRY, ASST. CASHIER

2548

THE FIRST NATIONAL BANK

Capital $\$ 100,000$.

Surplus $\$ 50,000$

$$
\text { Valley City, North Dakota }
$$

\section{Sept. $29, ' 10$}

To Whom It May Concern :

We take pleasure in commending The Northern Seed Company of this city to farmers and those interested in the handling and growing of the better grade of garden and field seed procurable and suitable to the climatic conditions of this State.

Under the capable management of Mr. E. S. DeLancey of this city, this ccmpany has grown from an infant industry beginning with a capital of $\$ 3,000.00$ in 1906 , until at the present time a paid in capital of $\$ 37,000.00$ is employed in its continually increasing business.

The company conducts a wholesale and retail seed business, and through its reliable, prompt, and satisfactory methods of conducting its dealings, has succeeded in establishing a very successful business, the total amount of which in 1909 exceeded $\$ 100,000.00,65 \%$ of which had its origin through mail orders.

JOHN TRACY, Cashier.

\section{Our Guarantee}

We Guarantee that all our seeds will conform to the provisions of the pure seed law of North Dakota. In all cases, where possible, before sending out they are analyzed by the State Seed Commissioner, Prof. H. L. Bolley of the Agricultural College of North Dakota. If upon receipt of our goods, and upon sending a sample to the State Seed Commissioner, you find they do not so conform, they may be returned to us prepaid, and money will be immediately refunded. We wish it understood that under no condition do we guarantee the crop.

IMPORTANT NOTICE: - If you buy your seed of dealers outside the state you are not protected by the above law. The North Dakota Seed Commission cannot prosecute outside the State, but can prosecute the home firms if they evade the law, consequently you deal with foreign seedsmen at your peril but are protected if you deal with your home firms. 
PLEASE DO NOT WRITE IN THIS SPACE

Date Received

Date Filled

Filled by

Checked by

No.

I give this order under the conditions of Northern Seed Company's Guarantee, which I have read.

Gentlemen: Please send the following seeds, etc., by

(State here if wanted by mail, express, or freight)

Name

Post Office

County .

.... State .

Street No., P. 0. Box

Nearest Railway Station

(State here name of town to which goods are When it is We should prefer shipping in this way.

When it is satisfactory that we should do this, please write YES here
EVERY ()RDER LARGE OR SMALL, WILL Receive Careful attention

Northern Seed Co,

VALLEY CITY, N. D.

\begin{tabular}{|c|c|c|}
\hline AMOUNT ER & CLOSI & \\
\hline & Dollars & Cts. \\
\hline P. O. Order. & & \\
\hline Express Order... & & \\
\hline Cash.. & & \\
\hline Bank Draft. & & \\
\hline Postage Stamps. & & \\
\hline Total. & & \\
\hline
\end{tabular}

NOTICE-Oftentimes when goods are ordered by mail we can send them very much more safe ly by express, charges being prepaid by us; if convenient, and you do not live too far from ex-

QUANTITY

Names of Seeds, Etc., Ordered

DOLLARS

cTs. 


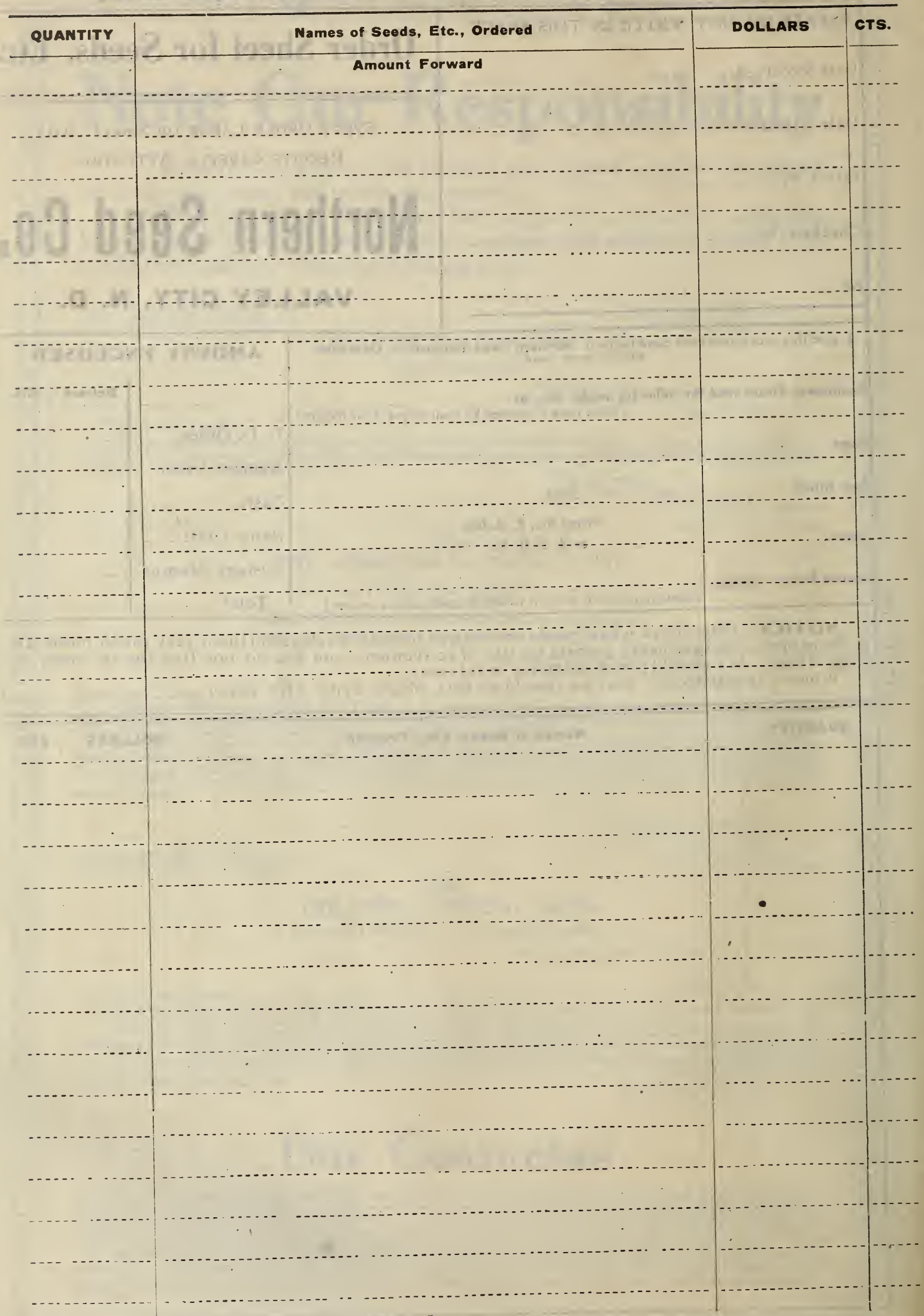




\section{GREETING}

It is with very kindly feelings that the manager of the Northern Seed Company greets their custo. mers of 1911. It has been your joint co-operation that has made it possible for the manager of this company to build the largest seed company in the Northwest. Without your co-operation it would have been impossible. For this we thank you. If our product and method of business had not been satisfactory to you, you would have long since withdrawn your patronage, and the Northern Seed Company would have been only a local institution instead of covering a large portion of the Northwest.

The quality of our goods are, and have been unsurpassed and since the farmers have found this out our business has extended to unprecedented limits. It always has been our aim, and always will be, under the present management, of the Northern Seed Company to handle nothing but the very best seeds and to give the very best of service possible.

Owing to the large increase in our business last year (an increase in March of over 600 per cent of the previous year) some of our shipments were somewhat delayed. For the coming year's business wo have doubled our capital and have doubled our capacity so that any delay in shipments are now and will be unnecessary.

For your information, we wish to impress upon your minds that we are not only seed dealers but the largest seed producers in the Northwest, and had more acres of seed under cultivation and under contract in Northern Minnesota and North Dakota than all other seed houses combined. We make this assertion for the reason there is a misunderstanding in the minds or the opinion of the public, of our status in the business.

We have a capital far in excess in the proportion of our business than most seed firms. We produce a larger per cent of our own stuff than nine-tenths of the seed concerns doing business in this territory. To such an extent has our growing production been extended that we often sell our surplus stocks to larger concerns of the East.

Thanking you for past business and soliciting your future orders, I remain,

Yours truly,

E. S. DeLANCEY,

Manager and Vice-President.

\section{FOR GENERAL DESCRIPTION OF OUR STOCKHOLDERS. DIRECTORS AND GENERAL POLICY SEE PAGES 32 AND 33}

\section{How to Order and Send Money}

We prefer that remittance be made by Bank Draft, Express or Postoffice Money Order and we guarantee the safety of money sent in any or these ways.

We accept stamps, currency, or coin but do not guarantee that money sent us in that form will reach us. Money may be sent safely by Postoffice Order, Bank Draft, Express Order or Registered Letter. If your order amounts to $\$ 1.00$ or more it is best to send by some one of the above methods.

When ordering give full name and address.

\section{Our Prices}

The prices in this catalogue are the prices of the world on similar grades of seeds, January 1, 1911.

The prices of grass seed fluctuate so materially during the season that it is impossible to guarante the within prices. They may be higher or lower, as the case may be. Our supply of "Home Grown" grass and clover seed is necessarily limited and we would advise you to order early.

Please note that the bushel price is relatively higher than the 100 pound rate. This is necessary to cover the extra expense of putting up small packages.

For Grass Seed, Clover or T'imothy, ordered by mail, include ten cents per pound extra for postage.

\section{Seeds by Express or Freight}

At prices here quoted we deliver all seeds to express or railway companies.

If seeds are ordered by express or freight at purchaser's expense, deduct 10 cents per pound from post paid prices.

Add 8 cents per pint or pound, 15 cents per quart on prices of Beans, Peas and Corn, when wanted by mail post paid. The prepayment of postage applies only to seeds quoted by the package, ounce 1-4 pound, 1-2 pound and pound, or where otherwise noted. pounds.

Purchaser has to pay transportation charges on everything quoted by the peck, bushel or hundred

When possible give full shipping directions. When shipping directions are not given we use our best judgment.

Boxes and paper bags free. No charge for cartage on seeds bought at these prices.

Under special rates made by the express companies we can ship seeds at a reduction of 20 per cent from regular rates. 


\title{
Freight Rates
}

The several railroads, recognizing the quality of our seeds, and realizing what we are doing for the farmers of the Northwest have very graciously given one-half rates on all grass seeds, seed wheat, seed barley, seed rye and seed flax, between the months of February 1st, and June 1st. Remember that you buy from us on a shorter ship and under a half-rate ruling, whereas if you buy from Twin City houses you will have the disadvantage of a longer haul, and slower delivery.

This half rate is applied by the Great Northern, the Northern Pacific and Ste Saint Marie railroads on all grass seed shipments between the first of February and the first day of June. To our customers living on the Great Northern, we land our shipments at Casselton, N. D., or Elbow Lake, Minn., free, they paying the half rate from those points to their station. To our customers living on the Milwaukee road, we land our shipments, free at Fairmont, N. D., or Linton, N. D., as the case may be. All shipments billed over the Northern Pacific or 'Soo' and Great Northern, take the half rate. This rate does not apply on shipments of corn, peas, beans or potatoes.

These rates give our northwestern customers a great advantage over any rate they could get from an eastern or southern house.

\section{Special Premium Offer}

With any order for Vegetable or Flower Seeds' to the amount of $\$ 1.50$, or any order for field seeds, other than grass seeds, to the amount of $\$ 5.00$, we will send free postpaid the four following twenty-page booklets:

Prof. Thomas Shaw on Alfalfa. (Price 15 cents.)

J. H. Shepperd on Root Crops for Stock. (Price 15 cents.)

O. O. Churchill on Forage Crops. (Price 15 cents.)

T. A. Hoverstad on The Potato Crop. (Price 15 cents.)

Total price 60 cents. Free with $\$ 1.50$ Garden or Flower Seeds or $\$ 5.00$ worth of Field Seeds, other than Grass seeds. solurce.

The above works are published and copyrighted by ourselves and can only be secured through this

\section{Special Premiums and Discounts}

Discount on Five-Cent packages and ounces: Any purchaser may select seeds in five-cent packages only, to the value of $\$ 1.50$ for each $\$ 1.00$ remitted. Seeds by the ounce to the value of $\$ 1.25$ for each $\$ 1.00$ remitted. This offer does not apply in any way to our ten-cent packages, or to the one-fourth pound, half pound, pint or quart prices, and cannot be included in any of the special premium offers.

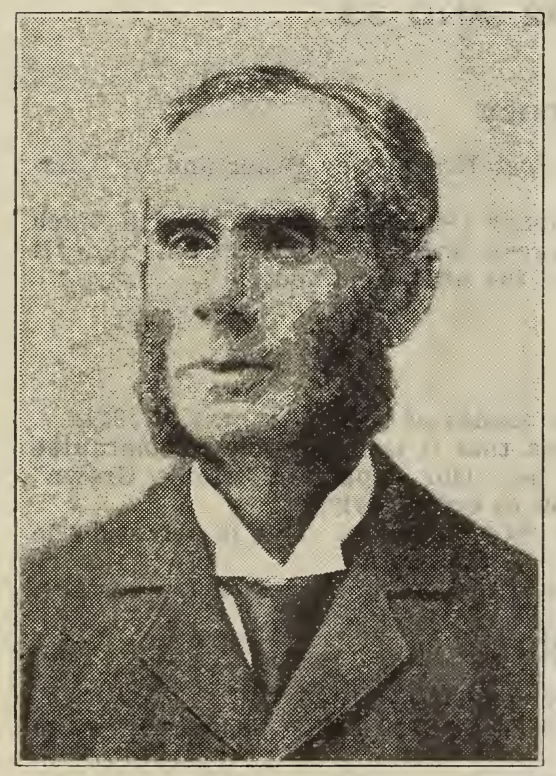

PROF. THOS. SHAW

\section{Directions for Planting All Kinds of Seeds}

The reader will notice at the head of every-variety of seed in this catalog that the directions for planting same are edited by Professor Thomas Shaw, the highest authority on this subject that we could obtain. We have given our customers the benefit of his experience and trust that owing to the valuable hints he has given you, that you will preserve this catalog for future use.

Prof. Thomas Shaw and his valuable service to the cause of good farming in the Northwest is too well known for us to repeat it here. Out of respect for Thomas Shaw and for your own benefit preserve this catalog so you can study the cultural hints from time to time.

\begin{abstract}
Northern Seed Company, Valley City, N. D.
Dear Sirs:-The seeds I purchased from you last spring were satisfactory in every respect. The germinating qualities were high, and they were all true to name. The varieties were well adapted to this locality. I like your catalog because you list only a few of the choicest varieties. Please send me your catalog, and you may expect an order from me. Wishing you success, I ain, Very truly. yours, W. M. TREADWELL, Adrian, N. D.
\end{abstract} Northern Seed Company, Valley City, N. D.

Sirs:- I am glad to say that the seeds bought from you are all more than recommended. The quality is unsurpassed. They have all matured earlier than any seed we have ever bought from a seed house, consequently, I shall be pleased to give you my orders as long as your standard is as high as now. Wishing you abundant success, I am Very respectfully yours.

GEO. RIEDASCH, Dogden, N. D.

Northern Seed Company, Valley City, N. D.

frenlemen:-I can truthfully state that your seeds are up to the atandard of thirty years of home gardening. I have not had seeds from any seed house of as good a grade as the seeds I got from you. I cannot speak too highly of your seeds. Yours truly,

MRS. SWAN HOBERG, Spring Brook, N. D.
Northern Seed Company, Valley City, N. D.

Gentlemen:-I am pleased to write you that we have found your seeds very satisfactory. We have tried many kinds but have had best success with yours.

Respectfully,

JOHN STEWART, Bowbells, N. D. 


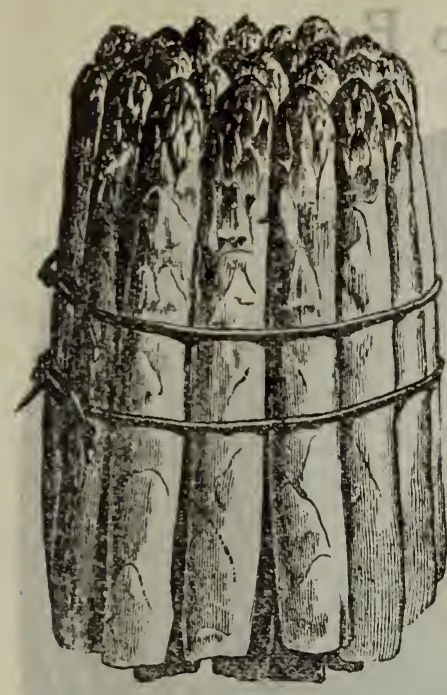

\section{Asparagus Seed}

Culture, (By Prof. Thos. Shaw): Asparagus grows readily from seed but may be more quickly established from the plants. The seed should be sown in the early spring in soil rich and mellow and in drills. These may be as close as 16 inches, but may also be wider to admit of growing some other crop, as radishes, between the rows, as the asparagus plants start slowly. The seed should usually be buried about an inch in the soil. One ounce of seed should sow about fifty feet of row and should produce from 300 to 400 plants. They are best transplanted when one year old, to the permanent bed, and the transplanting should always be done in the spring or early summer. The soil should have good drainage and should be deeply plowed and heavily manured. The plants are usually set at a depth of about 6 inches and in gardens $3 \times 3$ feet apart. Only a part of the covering should be put on at once. In the autumn the dead tops should be cut off with a hoe and the whole surface stirred to the depth of three inches and again in the spring. A good dressing of well decomposed manure should be given annually after a thorough cultivation in June. A crop will be produced the third year from sowing.

Columbia Mammoth White-Choice white stalks, good quality. Price: Pkt. 5 cents; one ounce, 10 cents; one-fourth pound 25 cents; one pound 75 cents. Postpaid.

\section{Artichokes}

Culture: (By Prof. Thomas Shaw): Artichokes furnish tubers that are excellent for table use, but will more commonly grown as food for swine and oth er stock. They grow readily in average soil, but will yield the largest crops on loams rich in vegetable matter. As swine are usually allowed to harvest They are planted fall or spring, grefow, it is important that they should be planted in a friable soil. The tubers may be or spring, preferable the latter, in rows 3 1-2 feet apart and one foot in th: rows. than two or three inches. successive crops annually by plowingation is about the same as for potatoes. They may be made to grow quently where plants are not plowing all the land before spring growth begins and cultivating subse-

Price: One-fourth bushel, 75 cents; bushel, $\$ 2.50$.

\section{Beets}

Culture: (By Prof. Thos. Shaw): The garden beet prefers a loam soil, with enough sand to make it friable, but will grow in any ordinary soil that is rich and easy to till. The seed should be sown in rows 16 inches distant and when a few inches high should be thinned to a distance of six inches between the rows. For summer use the seed should be sown quite early but for winter use not until late. May or and using not less than some large varieties of sugar beets are grown in rows not less than 24 inches apart the garden drill and for field to six pounds of seed per acre to insure a stand. The seed is best sown by the row so that and for field culture by machines ma de for such use. A little turnip seed sown will mark the row so that cultivation may begin sooner. The seed is buried from one to two inches. The roots should be thinned to 8 or 10 inches.

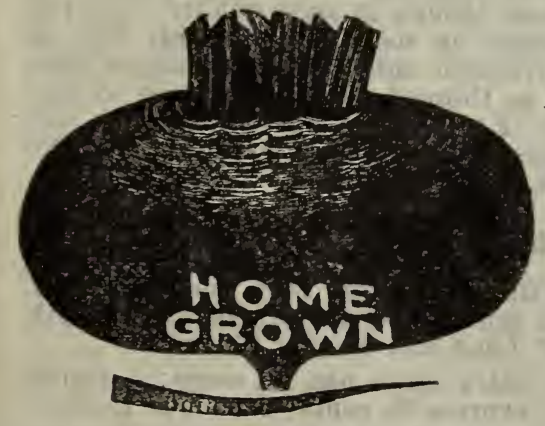

"Home Grown" Egyption Beet-This variety is excellent for forcing or first early crop out doors. Roots are very dark red, flesh zoned with lighter shade, crisp and tender when young. Very popular for home use and gardeners.

Price: Large pkt., 5 cents; ounce, 10 cents; one-fourth pound, 20 cents; one pound 55 cents.

Northern Seed Company, Valley City, N. D.

Dear Sirs:-I am well pleased with the seeds I received from you. They all came up good, and I had the best garden I ever raised in Dakota. I think you will get more orders next spring, from people around here, as my neighbors have asked me where I got my seed and said they would send to you next spring, and I surely will. Thanking you for prompt delivery, I remain Route No. 3 Yours respectfully,

Northern Seed Company, Valley City, N. D.

Gentlemen:- The garden seeds bought from you last spring all grew and did nicely, although the season was not a favorable one. The timothy, clover brome grass and alfalfa were exceptionally good, free from foul stuff and made a good growth.

$$
\text { W. M. BROWN, Ambrose, N. D. }
$$

Northern Seed Company, Valley City N. D.

Gentlemen:-I was more than pleased with the seeds I received from you last spring. And I think the Northern Grown seeds will grow better here in North Dakota than the Eastern grown seeds will. At least they did for me. I wish to receive your new catalog. At least they did fo MRS. WM. JENSEN, New Port, N. D. Northern Seed Company, Valley City, N. D.

Dear Sirs:-Last spring I ordered seeds from your house, and found them superior to any I have ever tried. I find them better adapted for the climate than Eastern or
Southern grown seeds.

Route No. 2.
Northern Seed Company, Valley City $N$. Gentlemen:-The seed purchased from you last spring germinated very good. I had a full stand of corn, which matured. I am pleased to know that we have one seed house in our state where we can get good seed and a square deal. Respectfully,

$$
\text { W. L. FORESTER, Hillsboro, N. D. }
$$

Northern Seed Company, Valley City, N. D

Dear Sirs:-We bought our garden seeds from you last spring and we were well satisfied. As long as we are so well satisfied, you can figure on our orders. Respectfully,

W. B. BEGGS, Turtle Lake, N. D. 


\section{Our Extra Early Blood Turnip Beet}

This is an extra selected strain and has proven a great success wherever grown. We shall supply thousands of our customers this year with this excellent strain. It is very early, early as any other variety grown and the color is a rich dark red and the illustration from a photograph shows the shape and appearance. It has a very small top, is fine grained and always grows very smooth and the beets are always of a very even size. This is one of the best varieties for early planting or for forcing for spring and summer crops or for use in the winter. It is very tender and crisp and highly prized in market wherever offered. It is a great keeper and will make an excellent crop in a few weeks after sowing the seed. We want every customer who has any room to raise beets to sow a packet of this extra selected early variety and we are sure it will be grown every year. more than 50,000 gardens contained this splendid beet in 1909 , and it is praised by all who tested it. Our crop of seed is sufficient we believe to supply all our customers.

Price:- Pkt., 5 cents; ounce, 15 cents; two ounces 25 cents; one pound, $\$ 1.00$.
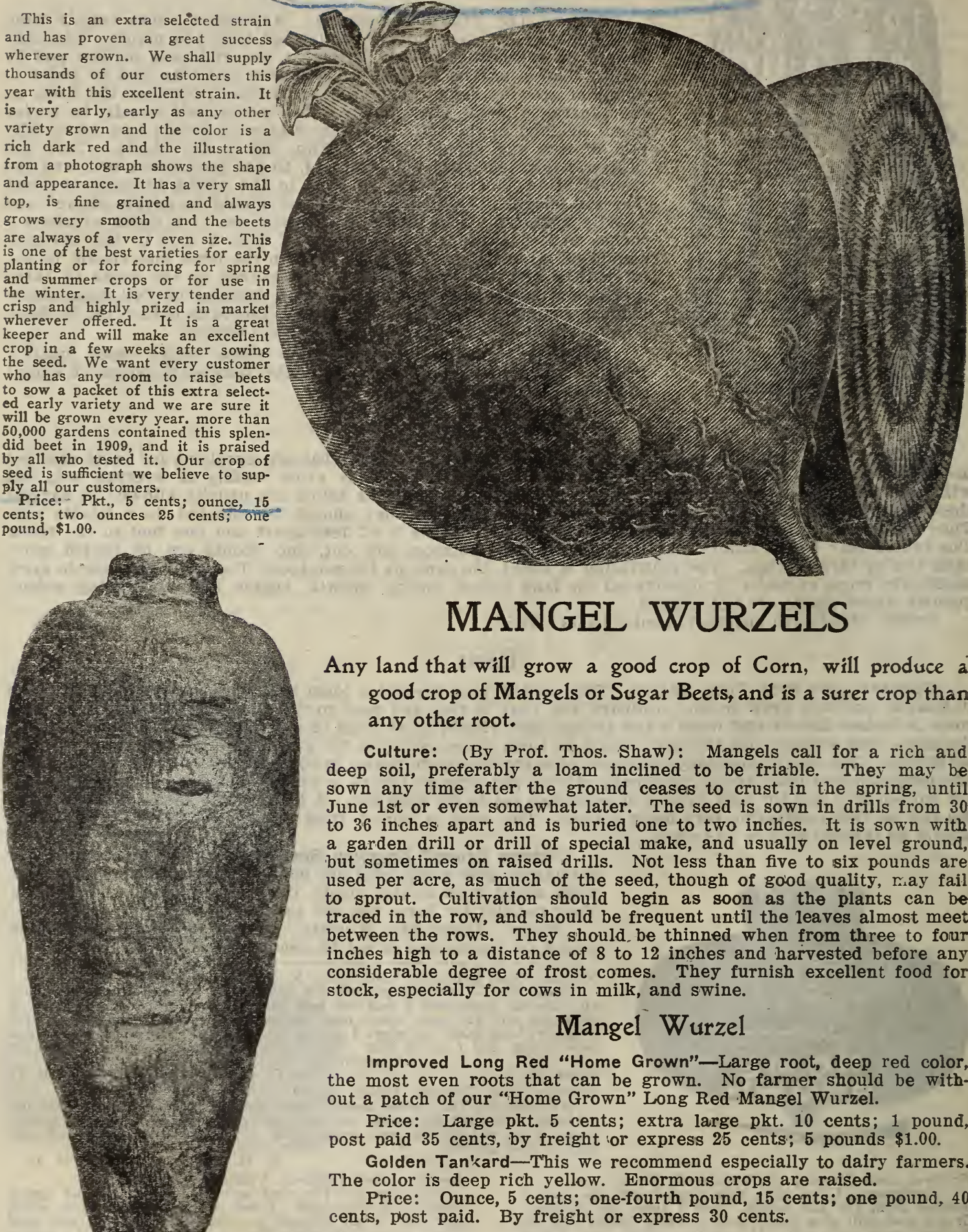

MANGEL WURZELS

Any land that will grow a good crop of Corn, will produce a good crop of Mangels or Sugar Beets, and is a surer crop than any other root.

Culture: (By Prof. Thos. Shaw): Mangels call for a rich and deep soil, preferably a loam inclined to be friable. They may be sown any time after the ground ceases to crust in the spring, until June 1st or even somewhat later. The seed is sown in drills from 30 to 36 inches apart and is buried one to two inches. It is sown with a garden drill or drill of special make, and usually on level ground, but sometimes on raised drills. Not less than five to six pounds are used per acre, as much of the seed, though of good quality, raay fail to sprout. Cultivation should begin as soon as the plants can be traced in the row, and should be frequent until the leaves almost meet between the rows. They should be thinned when from three to four inches high to a distance of 8 to 12 inches and harvested before any considerable degree of frost comes. They furnish excellent food for stock, especially for cows in milk, and swine.

\section{Mangel Wurzel}

Improved Long Red "Home Grown"-Large root, deep red color, the most even roots that can be grown. No farmer should be without a patch of our "Home Grown" Long Red Mangel Wurzel.

Price: Large pkt. 5 cents; extra large pkt. 10 cents; 1 pound, post paid 35 cents, by freight or express 25 cents; 5 pounds $\$ 1.00$.

Golden Tan'kard-This we recommend especially to dairy farmers. The color is deep rich yellow. Enormous crops are raised.

Price: Ounce, 5 cents; one-fourth pound, 15 cents; one pound, 40 cents, post paid. By freight or express 30 cents.

The Northern Seed Company, Valley City, N. D.

Gheapest

Food

For All

Live Stock again.

Gentlemen: I used your seeds this year and had good success. I shall use them Yours truly,

MRS. E. W. PATTON, Steele, N. D.

Northern Seed Company, Valley City, N. D.

Dear Sirs: The seed I bought from you last spring were all $O$. $K$., and $I$ wish

to get some more next spring Yours very truly

YNDREW HOLMQUIST, Ambrose, N. D. 


\section{BEANS}

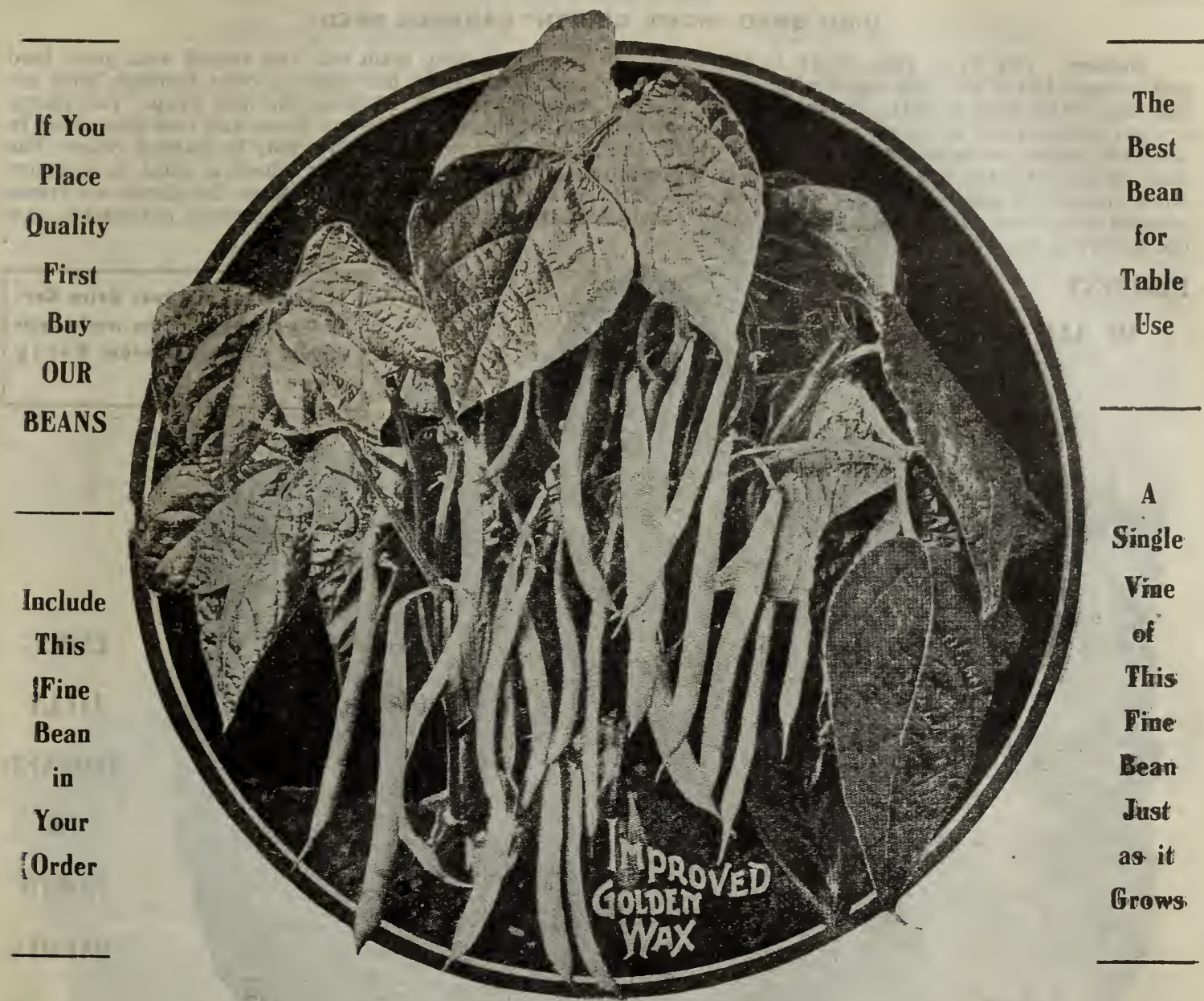

\section{Improved Golden Wax or Butter Beans}

Culture: By Prof. Thos. Shaw): Beans may be grown on a great variety of soils but by no means equally well. The best soils for growing beans are rich loams with a goodly sprinkling of sand in them and well drained. Essentially they comprise the two classes, bush and pole beans, the former being most frequently used shelled and the latter in the pod. Field crops of bush beans are usually sown with a horse drill and garden crops of all kinds by hand or with a garden drill. The seed is buried two or three feet distant, and with three to six inches between the beans. Clean cultivation should be given until the plants begin to bloom, when it should cease. The crop is usually harvested by aid of a bean harvester, and threshed in a bean thresher. The pole varieties are grown in hills four feet apart each way with a pole six feet long in each hill and about six seeds are planted in each hill. Others grow them in rows and make a trellis for them to climb on. No variety should be sown until the ground gets warm. Dwarf beans for using green, may be sown on until near the first of August in many climates.

"Home Grown" Golden Wax Beans-A very large pod, of a rich golden wax color. The earliest bean on the market.

Price: Pkt. 5 cents; one-half pint, 10 cents; 1 pint, 20 cents; quart 30 cents; peck, $\$ 1.25$. If ordered by mail 4 cents extra for every one-half pint.

Extra Early Red Valentine-(Round Pod.) Pods are usually ready to pick in about forty-three days from germination. Vine erect; pods medium length, curved, cylindrical, with crease in back, very fleshy, crisp and tender; seed long, of medium size.

Price: Pkt. 5 cents; one pound, 15 cents; pint, 15 cents; quart, 25 cents; one-fourth bushel, $\$ 1.30$; bushel $\$ 4.50$.

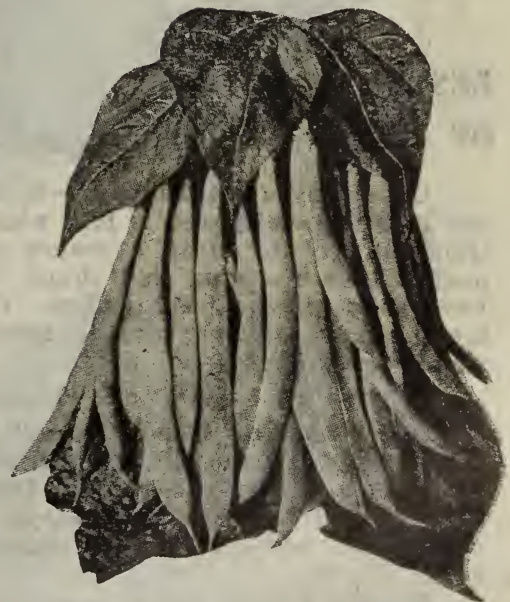

Our Improved Valentine Wax

Improved German Black WaxPods are clear yellowish white color. Seed small and black, extra early and a general favorite. Price: Pkt., 5 cents; one-half pint, 10 cents; one pint, 20 cents; quart 30 cents; pecks, $\$ 1.25$. Add 4 cents extra per one-half pint if ordered by mail. 


\section{CABBAGE}

\section{HIGH BRED "HOME GROWN" CABBAGE SEED.}

Culture. (By Prof. Thos. Shaw.): Cabbage call for a rich deep loam soil well stored with plant food and moist. Early cabbage especially, call for a very rich soil. It is not easy to over fertilize land for cabbage. The seed of early cabbage is best started under glass, and is buried one inch deep. The plants are set out as soon as frost disappears in rows with 30 to 36 inches between them and two feet apart in the rows when horse cultivation is to be given, but under other conditions they may be planted closer. The seed of late cabbage is frequently sown in the ground, putting in a few seeds where a plant is to grow. More commonly the seed is sown in beds with 12 in ches between the rows and later the plants are transplanted into rows three feet apart with the plants equally distant in the row. Too much cultivation cannot be given to cabbage.

\section{EARLIEST}

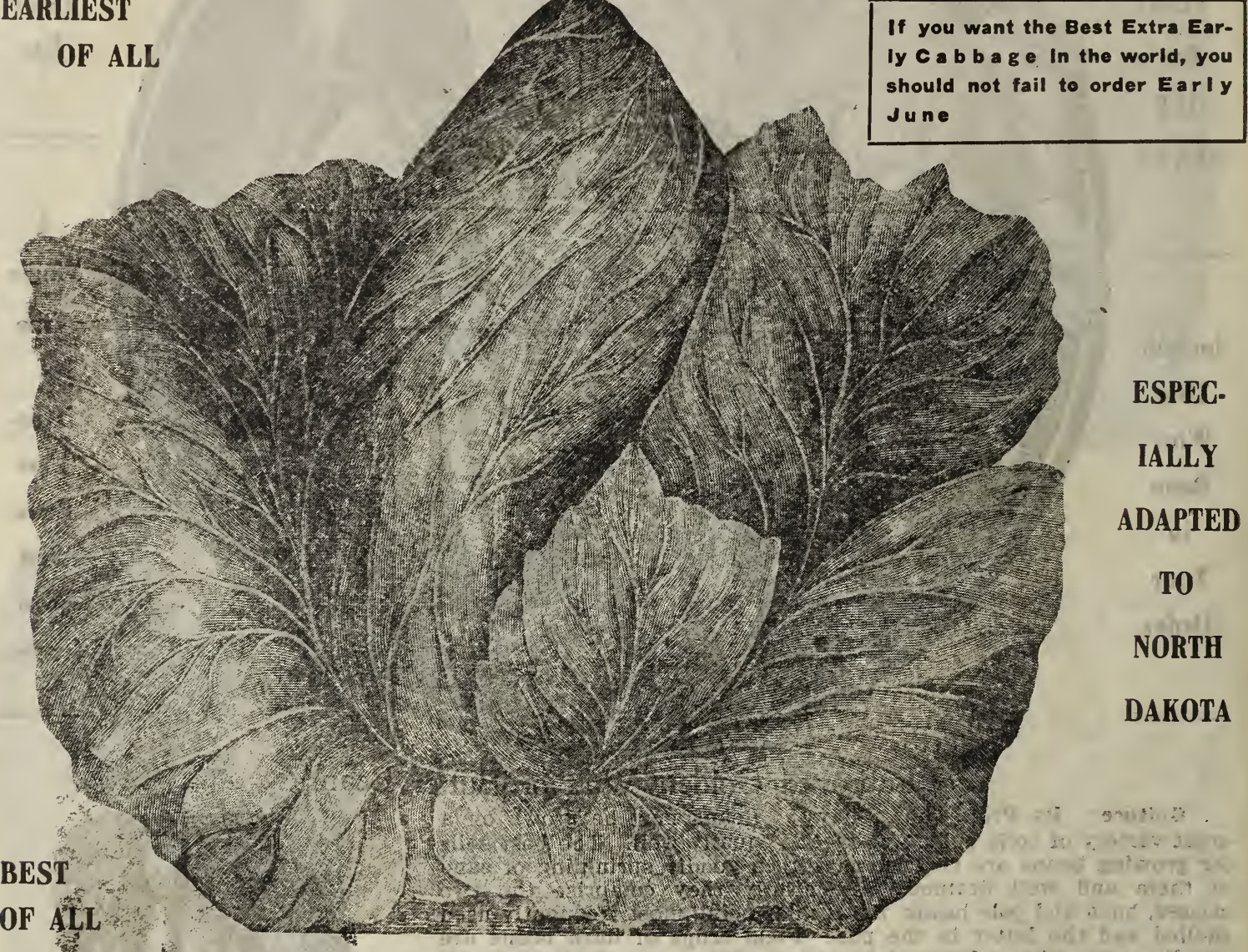

Que Early June Cabbage-Earliest of all! This is our sreat specialty and is just what its name indicates. Quiekest growing of all cabbages and will please every one. Heads are good size, shape shown by illustration. Very solid, of the best quality. Can be planted close together and always sure to head. A great favorite Where once planted.

Price: Pkt., 5 cents; oz., 15 cents; two ozs. 28 cents.

Our Stândard "Home Grown" Extra Early Winnig. stadt-This cabbage is the hardiest of any of the early varieties, and seems to be freer from the cabbage worm than any of the other varieties. Heads are conical shaped and are suitable for either summer or winter use.

Price: Pkt. 5 cents; ounce, 15 cents; one-fourth pound, 45 cents; 1 pound, $\$ 1.45$.

Northern Seed Company, Valley City, N. D. us.

Dear Sirs:-The seeds we received from you all grew fine for I remain, ever yours,

F. L. HALL, Boz, N. D.

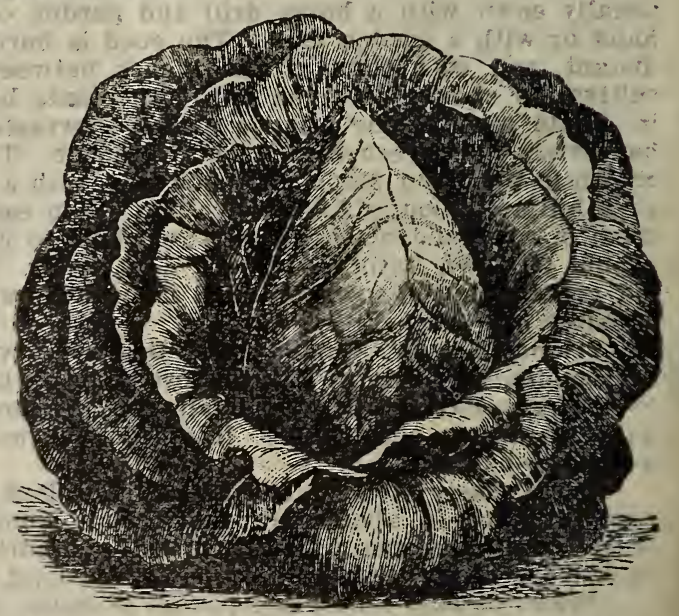




\section{Cabbage Continued}

Our Special Large Drumhead-This is a very large variety, often weighing from 20 to 30 pounds. The leaves fold very closely forming an extraordinary solid head. A very desirable winter variety.

Prices: Pkt. 5 cents; ounce, 20 cents; one-fourth pound, 60 cents; 1 pound $\$ 2.00$.

Northern Seed Company, Valley City, N. D.

Dear Sirs:-I can say I am well pleased with your seeds. They did well. Nothing but "Home Grown" seeds for me, Yours,

A. BURNETT, Lemon, S. D.

Northern Seed Company, Valley City, N. D.

The seeds I got from you were all right. They grew well and are doing fine. I think it pays to get seeds grown as near home as possible. Respectfully yours,

S. T. LINN, Center, N. D.

Northern Seed Company, Valley City, N. D.

Dear Sirs:- The seeds bought of you last spring were all right in every particular. I planted early. We had much cold weather and the seeds were slow to germinate on account of the cold, but when it got warm enough for anything to grow but few of the seeds failed to germinate and grow, notwithstanding we had a snow storm and freezing temperațure after they were planted. Sincerely yours,

ORPHA MEYERS, Belfield, N. D.
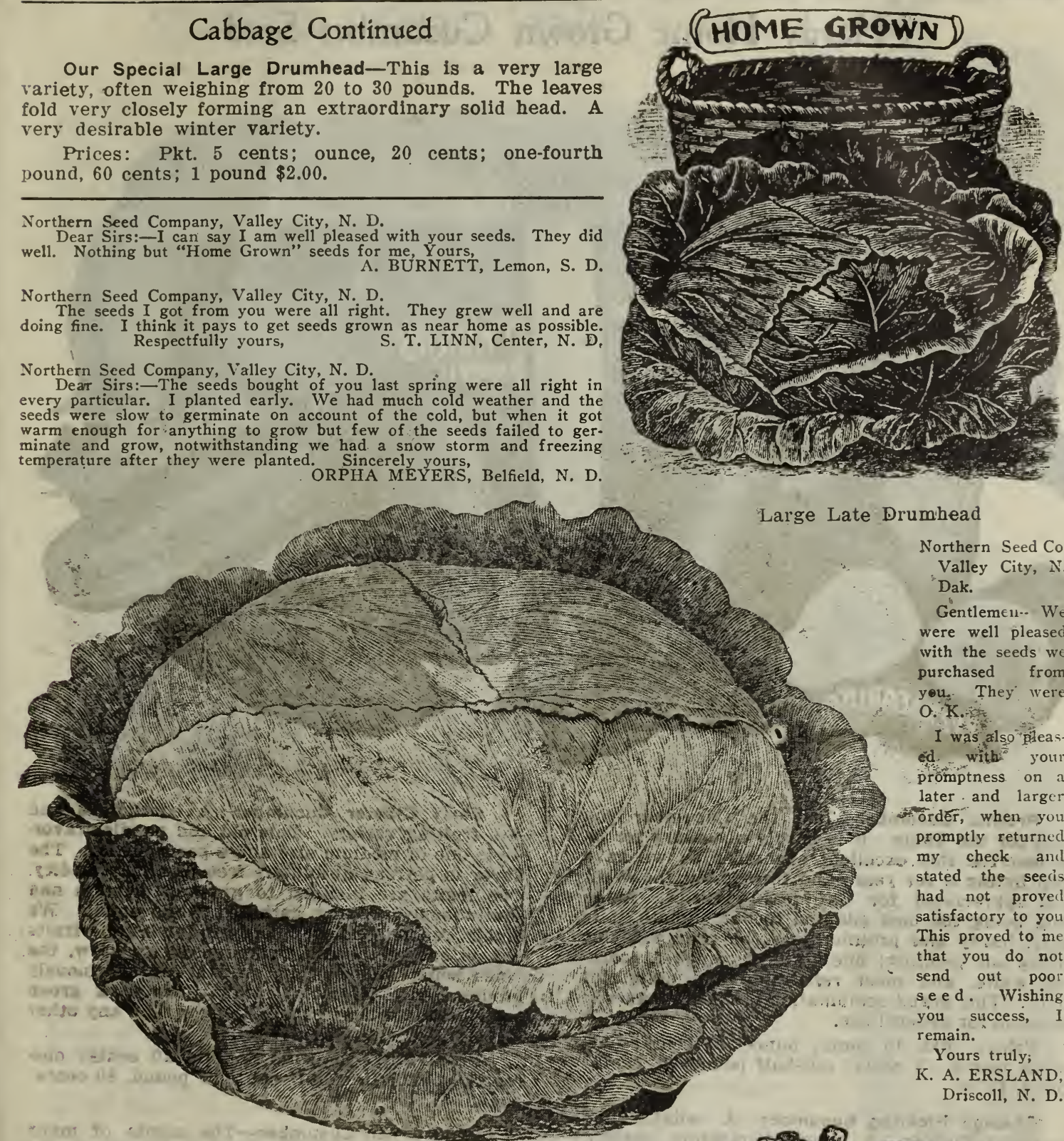

Northern Seed Co.
Valley City, N.

Dak.

Gentleme11.. We were well pleased with the seeds we purchased from you. They were O. K.

I was also dileas ed. with your promptness on later and larger

order, when you promptly returned my check and stated the seecis had not proved satisfactory to you This proved to me that you do not send out poor seed. Wishing you success, I remain.

Yours truly;

K. A. ERSLAND, Driscoll, N. D.

Matchless "Home Grown" Premium Flat Dutch Cab. bage-Solid, flat on top. An excellent keeper. This is superior to any strain of Flat Dutch Cabbage on the market and they are hardier.

Price: Large Pkt., 5 cents; ounce 20 cents; one-fourth pound, 60 cents; 1 pound, $\$ 1.90$.

6 "Home Grown" Extra Early Wakefield-This variety has few outside leares. It is solid, compact and conical in shape. Our stock has none superior.

Price: Pkt. 5 cents; ounce, 20 cents; one-fourth pound, 60 cents; pound $\$ 2.00$.

Northern Seed Company, Valley City, N. D.

Dear Sirs:-I wish to say the seeds I hought from you last spring were satisfactory in every respect. They were better than advertised to be. You may count on me for an order whenever I need any thing in your line. Wishing you success $I$ am

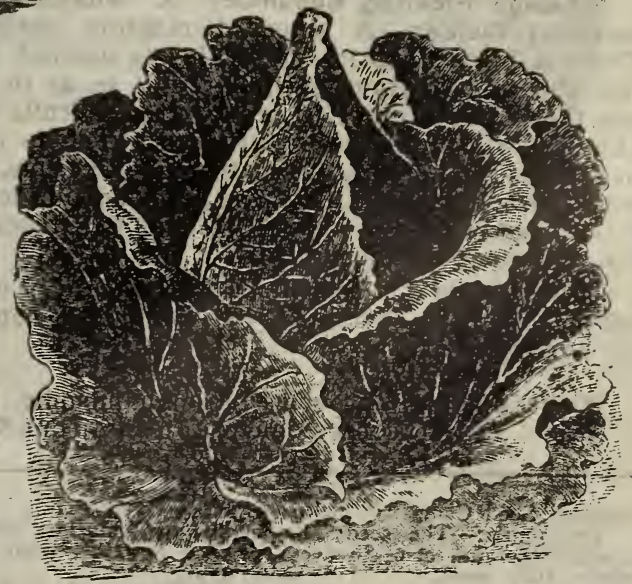

Respectfully yours, OSCAR MONSON, Lily, S. D. 


\section{Hardy Home Grown Cucumber Seed}

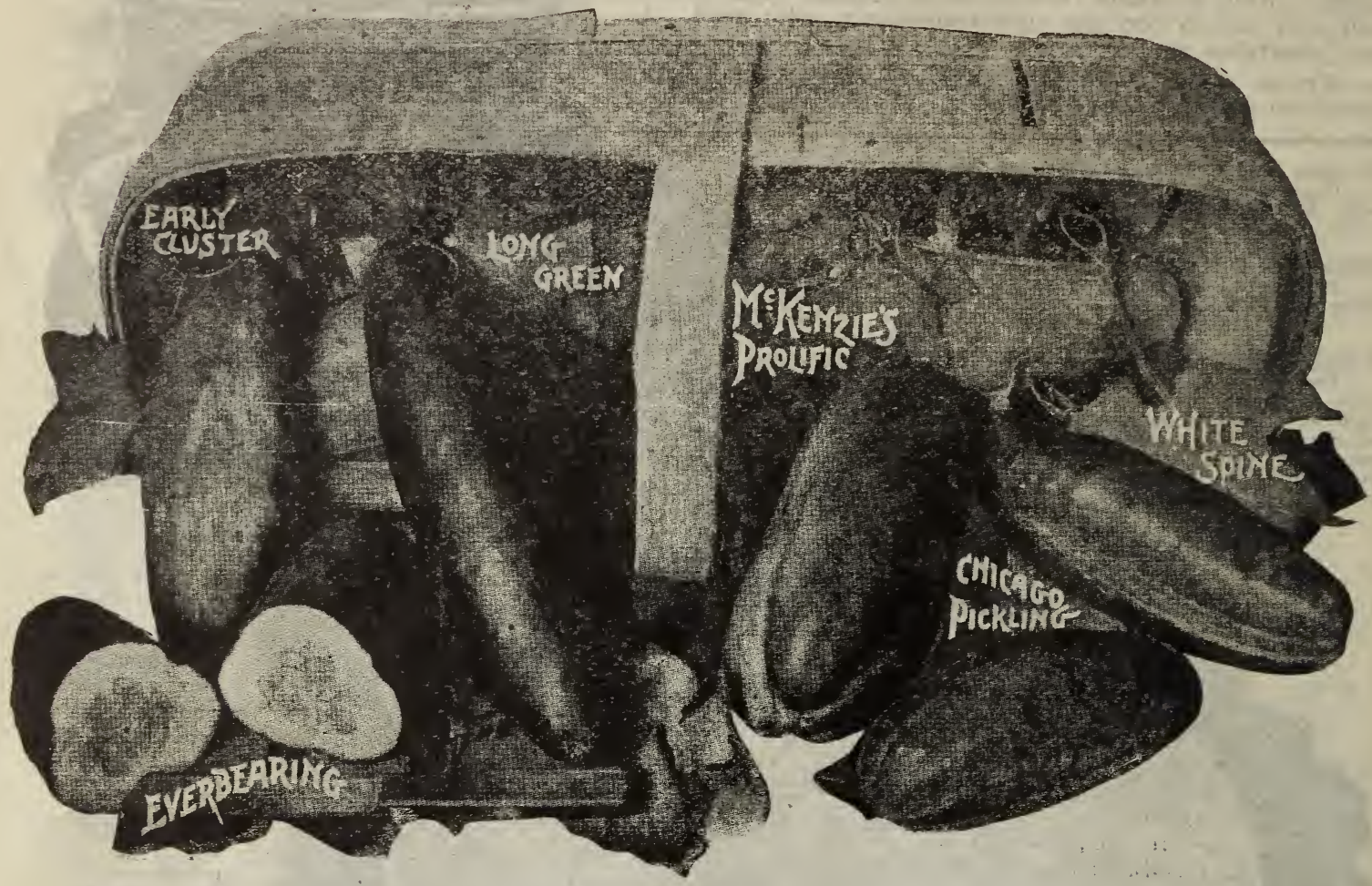

Prolific Cucumber-Just the Cucumber you want for the Table. It' is hardly necessary for us to describe this excellent cucumber as we have been listing it for years and throughout the West it is appreciated for its ideal qualities. Aside from being the best adapted to our climate, it is early, hardy and prolific; just the right size for slicing and pickling; fine grained, compact, sparkling white, and most refreshing and delightful flavor. This grand combination of merits makes it desirable for general use.

Price: Pkt. 10 cents; ounce, 25 cents; onefourth pound, 9 cents; one-half pound, 95 cents; pound, $\$ 1.75$.

Chicago Pickling Gucumber-A reliable and Bountiful Yielder. A splendid pickling variety. Where a large quantity of pickles is desired the fruit should be gathered while small so as to insure the greatest crop; to produce large fruits for table use will stunt the growth and check its productiveness. The vines are extremely vigorous, remaining in strong, healthy growing condition long. er than any other variety. The skin is extremely thin, and tender when-piokled.

Price: Pkt., 5 cents; ounce, 15 cents; onefourth pound, 35 cents; one-half pound, 65 cents; one pound, $\$ 1.25$.
Early Cluster Cucumber-A continuous and late fruiting variety. This old and popular favor. ite is one of medium size and a good pickler. The flavor is perfect, absolutely free from any acidity. The fruits are inclined to grow in clusters and continuously, if kept gathered while small. We highly recommend it, not only for its fine fruits but as one of the most satisfactory to grow, the vines being vigorous in growth and enormously productive. The fruits retain their dark green coloring and crisp freshness longer than any other variety.

Price: Pkt. 5 cents; ounce, 20 cents; onefourth pound, 45 cents; one half pound, 80 cents; pound, $\$ 1.50$.

Long Green Cucumber-The merits of many combined in one. Long Green is the handsomest and best of all long green cucumbers. Always straight and well formed, they never turn yellow, and from a marketable point of view, are considered unequalled. The flavor is simply superb. Medium early, prolific and continuous producer of uniform large and symmetrical fruits of an intense rich deep green color.

Price: Pkt., 5 cents; ounce, 15 cents; onefourth pound, 45 cents; one-half pound 85 cents; one pound $\$ 1.50$.

White Spine, Improved-Large handsome, unform fruits. Crisp and fine flavor.

Price. Pkt., 5 cents; ounce, 15 cents; one-fourthpound, 35 cents; pound, \$1.15.

Northern Seed Company, Valley City, N. D.

Gentlemen:-The seeds I bought of you last spring proved to be first class in every respect, and just what you claimed they were.

Route No. 1.
F. H. LAURENT, Lisbon, N. D.
Northern Seed Company, Valley City N. D.

Gentlemen:-Last spring I bought some garden seeds from you, and I am glad to say that they gave very gond results. 


\section{SUPERIOR CARROT SEED}

\section{The Best of the Standard Sorts of Carrots.}

Culture: (By Prof. Thos. Shaw): The carrot will grow successfully on any good soils, but it grows best on mellow solls, as rich sandy loams underlaid with a subso'l more or less porus. As the plant grows very slowly for a time the seed should be sown only on clean land. The seed may be sown from the opening of spring until June 1st, but the best crops are sown early. In the garden the rows may be so close as 14 inches for the small varieties and as distant as 24 inches for varieties grown for live stock under methods of field culture. The seed is sown by hand or with drills, and is best buried about one inch deep. Two pounds will sow one acre for stock feeding, for which carrots have high adaption. A small

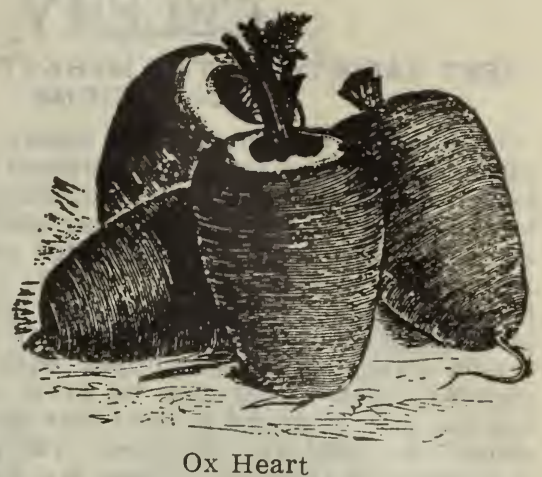

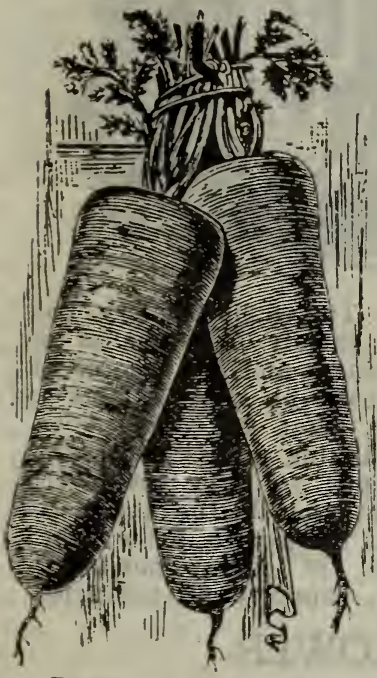

Danver's Half Long. amount of turnip seed sown with the carrot seed will make it possible to attack weeds at an earlier period which is very important. When two or three inches high, they should be thinned to one to three inches to the row.

"Home Grown" Danver's Half-Long-This is a first class carrot for all kinds of soil. Roots grow to a good size. Flesh dark orange yellow. Early harvest and a good keeper. This carrot is excellent for table use and is also largely grown for feeding purposes: Price: Pkt., 5 cents; ounce, 10 cents; one-fourth pound, 25 cents; pound, 85 cents.

"Home Grown" Oxheart or Gureande-Is intermediate between the Half Long and Horn varieties; tops small for size of roots, which are comparatively short, reaching a diameter of seven inches, terminating abruptly in a small tap root. The flesh is of a bright orange, fine grained and sweet. This is a desirable variety for soil which is so hard and stiff that longer growing roots would not thrive in it. When young excellent for table use and when matured equally good for stock. Price: Pkt., 5 cents; ounce, 10 cents; one-fourth pound 30 .cents; pound, 90 cents.

The Yield of Mastadon Carrots is anywhere from 8 to 15 hundred bushels per acre. Extraordinary yields go considerably over this. Compare this with the present price of oats, and you will see for yourself that it is a paying proposition for the farmers of the Northwest.

Mastadon Carrot-The flesh is white and solid, very sweet in flavor They do not easily break in pulling. This variety will give the greatest yield per acre of any carrot grown. Prices: Large Pkt., 10 cents; onefourth pound, 30 cents; one-half pound, 50 cents; one pound, 90 cents; 5 pounds $\$ 3.75$.

Our 20 page pamphlet, by J. H. Shepperd, of the N. D. Agricultural college, sent free, post paid, with every order for stock carrots.

Are You Short of Horse Feed? Have you any Mastadon Carrots for your horses for winter feed? No feed in existence is so beneficial to horses as Mastadon Carrots. Easily grown, sure crop, very large yielder. Be sure you are supplied the coming year.

Northern Sced Company, Valley City, N. D.

Dear Sirs:-The seeds I ordered from you last spring could not be beaten. The peas made the quickest growth of any I have ever seen. They were the American. The other seed house, and and melons made good growth. I would not buy seeds froom any satisfactory.
Yours sincerely of the Dakotas to you. Everything was ROBERT E. MARIONON, Fairburn, S. D.

Northern Seed Company, Valley City, N. D

Sirs:-In regard to the seeds I obtaine

with them. All seeds came up and did well. Yours truly,

MRS. H. GILLETTE, Roscoe, S. D.

Nothern Seed Company, Valley City, N. D.

Gentlemen:-The garden seeds we received from you grew fine. They were the best we have had in the state. We had a better garden this year than we had for ten
years.

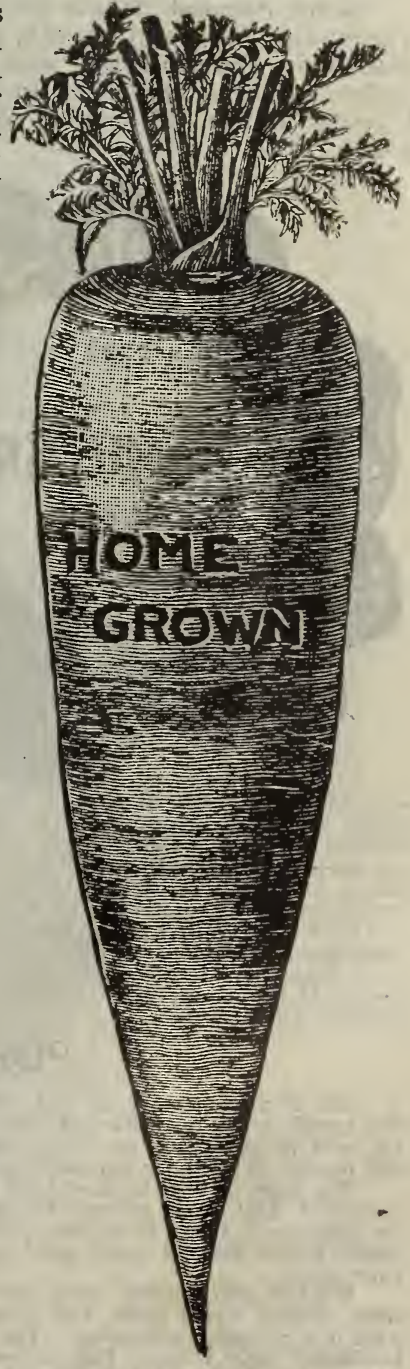

Mastadon Carrot 
$$
\text { CELERY }
$$ \\ BEST VARIETY ON THE MARKET FOR NORTHERN CONDITIONS.}

Culture: (By Prof. Thos. Shaw). Celery grows best on a rich and deep sufficiently drained humus soil, as black loam such as is found in drained sloughs and bogs, but it may be grown successively in any good garden soil. More commonly the seed is sown under glass in February or March and while the plants are yet quite small they are transplanted into rows in hot beds until large enough to plant in trenches, which is from May onward. The plants should have the leaves clipped back before each transplanting. Later seed may be sown outside on very rich soil one inch deep and in rows nine inches apart. The soil should be firmed over the seed. The plants are finally set in furrows or trenches. These are made six inches deep. Two or three inches of well rotted manure is then usually thrown into the trench and mixed with the soil, the trench being practically filled at the same time. The rows are three feet apart for the dwarf sorts and four feet for the larger sorts and the plants are set six inches apart. The roots should not be exposed and the ground well firmed around them when planting. Earth is drawn against the plants with the hoe or plow as the plants grow, to aid in bleaching them.

Giant Paschal "Home Grown" Celery-Popular sort for winter use. Large in growth, of a rich creamy yellow when blanched. Stocks bright and crisp. It blanches with but slight "earthing up" easily in five or six days. Price: Pkt., 5 cents; ounce, 25 cents; one-fourth pound, 50 cents; pound, $\$ 1.75$.
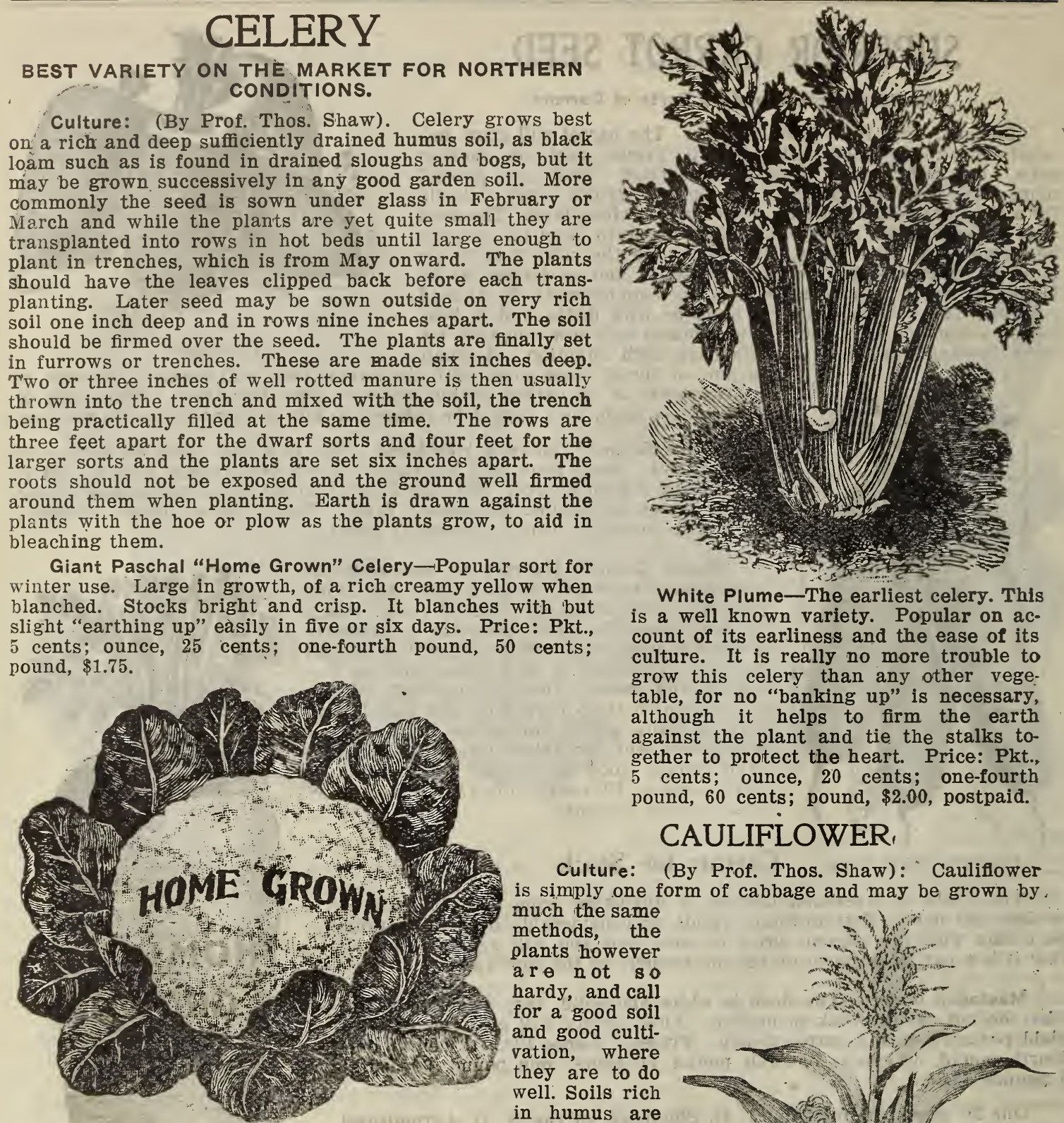

White Plume-The earliest celery. This is a well known variety. Popular on account of its earliness and the ease of its culture. It is really no more trouble to grow this celery than any other vegetable, for no "banking up" is necessary, although it helps to firm the earth against the plant and tie the stalks together to protect the heart. Price: Pkt., 5 cents; ounce, 20 cents; one-fourth pound, 60 cents; pound, $\$ 2.00$, postpaid.

\section{CAULIFLOWER,}

Culture: (By Prof. Thos. Shaw): 'Cauliflower is simply one form of cabbage and may be grown by much the same methods, the plants however a re n ot so hardy, and call for a good soil and good cultivation, where they are to do well. Soils rich in humus are especially good. The plants are best started under glass in the northern climates and after being gradually hardened by exposure are transplanted intn rows 24 to 30 inches distant and about the same in the line of the row. They re even more susceptible to frost in the spring than cabbage. Frequent cultiation is necessary. When the head commences to form the outside leaves should be drawn together over it to preserve the white color.

OUR SNOWBALL-Is excellent for both early and late planting, and unsurpassed by any strain of Snowball on the market. The heads are from 8 to 10 inches in diameter and snowy white. Price: Pkt., 15 cents; one-fourth ounce, $\$ 1.15$; ounce, $\$ 2.00$; oneqfourth pound, $\$ 7.50$. An ounce of seed will produce 3,500 plants.

\section{POP CORN}

Our Pop Corn we grow and select with the idea of maturity in the north. We handle large quantities of Southern Pop Corn, for popping purposes, but for seed purposes, we send out nothing but what is grown in the North and for seed purposes, we send out nothing but

The boys and girls should all have a little pop corn in the garden and should at least, raise enough for their own use, to pop during the long winter evenings. There is no one little thing that goes into the garden that the entire family gets so much good out of. Be sure to remember pop corn in your order. order. riety, having larger ears, and producing more abundantly. Six ears to the stalk is a common occurrence. The kernels are sharply pointed, making a very handsome ear. Price: Pkt. 5 cents; pint, 20 cents; quart, 35 cents; veck, $\$ 1.00$. Add 4 cents for each one-half pint ordered by mail.

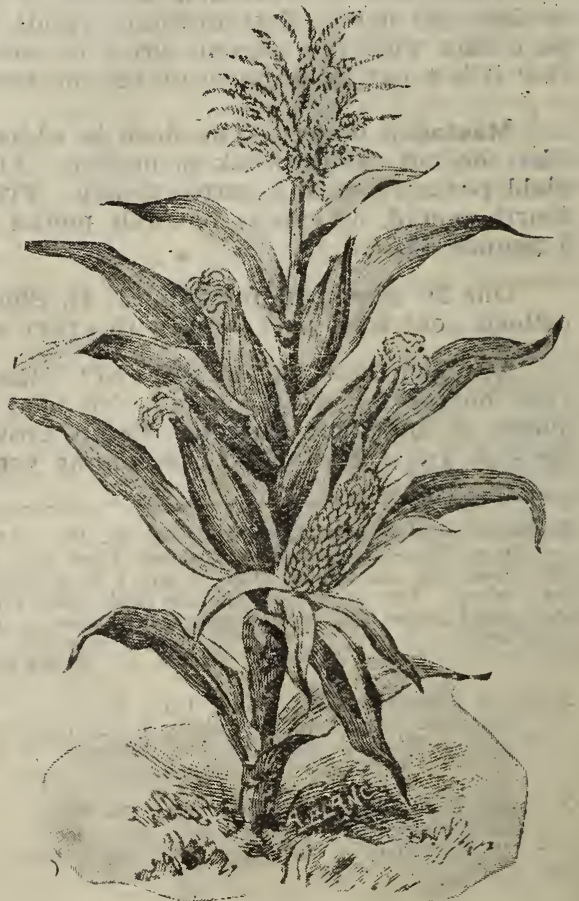




\section{SWEET CORN, EXTRA EARLY VARIETIES}

THE TRIED VARIETIES

Culture: (By Prof. Thos. Shaw): Sweet corn like field corn grows best in a mellow loam soil. It will mature more early in a sandy than in a clay loam. The soil should be both mellow and rich. The bulk of the seed crop should be planted during the last half of May, but for early use some of the seed may be planted fully two weeks earlier. Although it may be grown in hills 36 to 42 inches apart each waJ and with four to five stalks in a hill, it is now more frequently grown in gardens in rows with seven to nine inches between the plants. The seed is buried about two inches in the soil. It is planted by hand, with a planter or a seed drill. The ground should be raked over or harrowed before the seed is up and also later and should be kept clean subsequent ly and mellow by cultivating shallow as often as necessary. Pop Corn is grown in the same way as Sweet Corn.

N. S. Co's. "Home Grown" Peep of Day Sweet Corn-The Sweetest, the Earliest, the Best. Is unsurpassed for earliness and sweetness, it also has a wonderful productiveness. The stalks produce from two to five ears each. Price: Large pkt., 5 cents; one-half pint, 10 cents; quart, 25 cents. Add 4 cents for each one-half pint ordered by mail.

Early White Cory - "Home Grown" is favorably known in all parts of the country. It is adapted to short seasons and may be recommended for general use. Price. Large pkt., 5 cents; one-half pint, 10 cents: quart, 25 cents; peck, $\$ 1.25$. Add 4 cents extra for each one-half pint ordered by mail.

"Early Minnesota"-It's Early, It's Sweet, It Satisfies. Standard early sort, good quality, especially recommended for a major portion of the sweet corn crop. Extra good table corn; a good yielder. Price: Large pkt. 5 cents; one-half pint, 10 cents; quart, 25 cents. Add 4 cents extra for each one-half pint ordered by mail.

\section{GOLDEN BANTAIV SWEET CORN}

Surpassingly delicious in flavor. The: introduction of Golden Bantam Sweet Corn affords a delicacy of surprising quality and rich flavor. The first trial of this superb Sweet Corn, creates a taste which cannot be soon freates a and results in an immediate call for more.

EARLINESS - Golden Bantam Sweet Corn is not the earliest sweet corn, as Peep'o Day matures from week to ten days in advance of Golden Bantam planted at the same time. Bantam planted at the same time. It, however, matures very early and is suit. able, not only for early planting, fon account of its hardiness) but a succession of sowings may be made during the season. giving a continuous supply until fall. Prices: Large pkt., 5 cents pint, 20 cents; quart, 35 cents postpaid pint, 20 cents; quart, 35 cents postpaid. quart, 25 cents; four quarts 90 cents; one-fourth bushel, $\$ 3.50$.

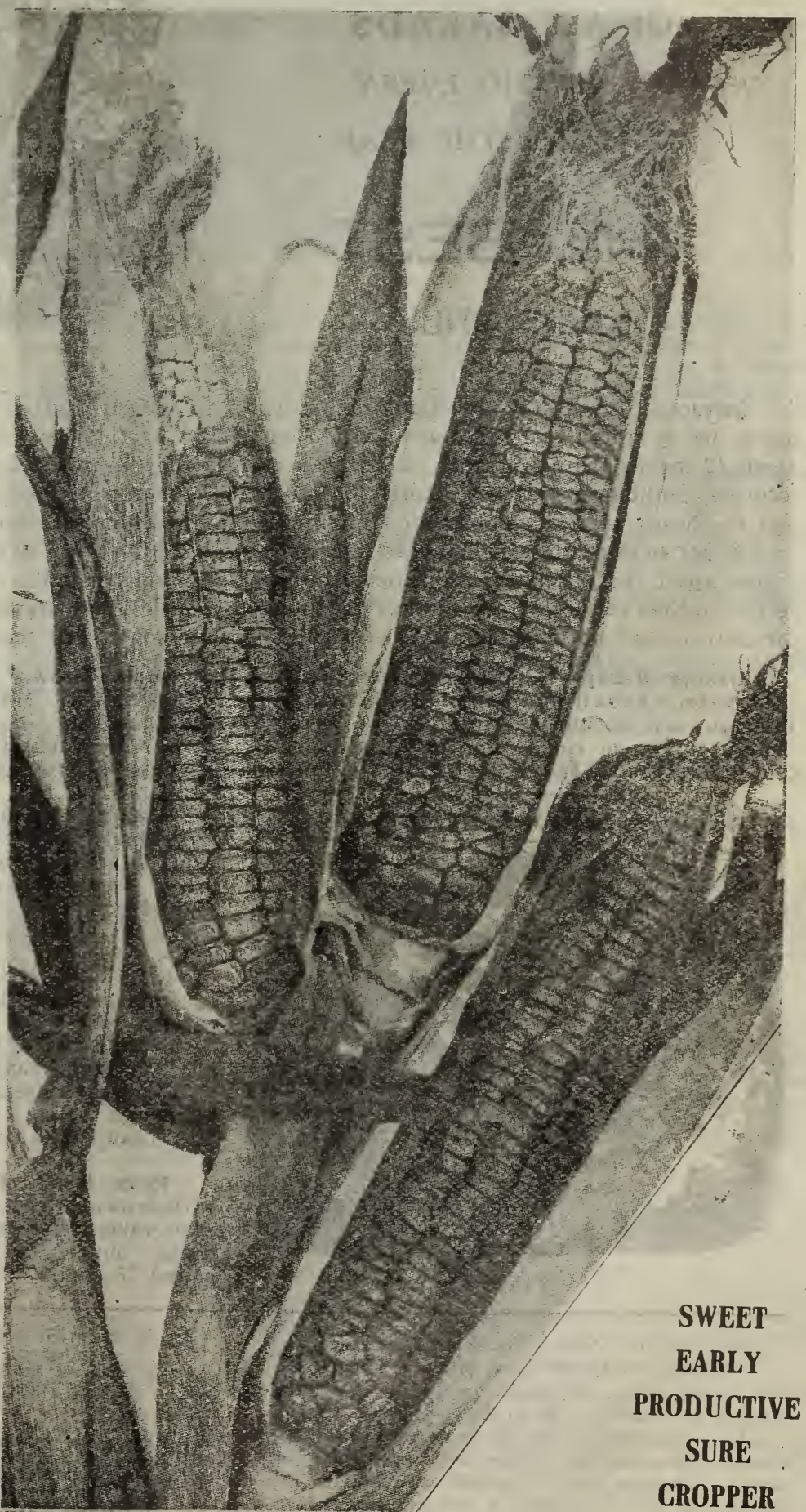

Golden Bantam Sweet Corn 


\section{LETTUCE}

THE MOST USED

OF ALL SALADS

IN DEMAND EVERY

MONTH OF THE YEAR

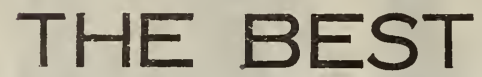

KINDS ONLY

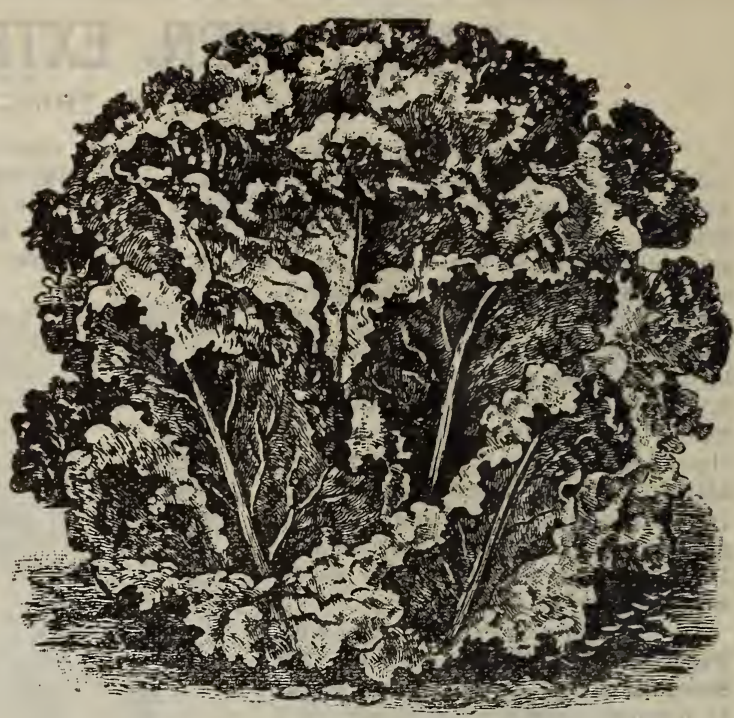

Early Curled Silesia

Culture: (By Prof. Thos. Shaw): Lettuce is frequently started in hot beds or in cold frames, the plants being taken from there and planted out in the open. They are sometimes planted in squares about 12 inches apart each way. In other instances they are planted in the line of the row between early cabbage, cauliflower or other plants. In the garden the seed is sown in rows 14 or 15 inches apart and the heads are cut off when ready for use without having previously thinned the plants, but such lettuce is not so crisp and good as head lettuce. In growing the latter in the open, the seed is sown in rows 1 ? inches apart and the plants are thinned to about the same distance. The seed should be buried from 1 to 1 1-2 inches and it will grow in any good soil. By sowing at intervals of about three weeks, the season for lettuce may be much prolonged. The crop when sown early may be followed by other crops.

Dakota 20 Day-We have obtained the earliest lettuce known and especially recommend. this for early spring planting. Price: Pkt., 5 cents; ounce, 10 cents; one-fourth pound, 30 cents; one pound, $\$ 1.25$.

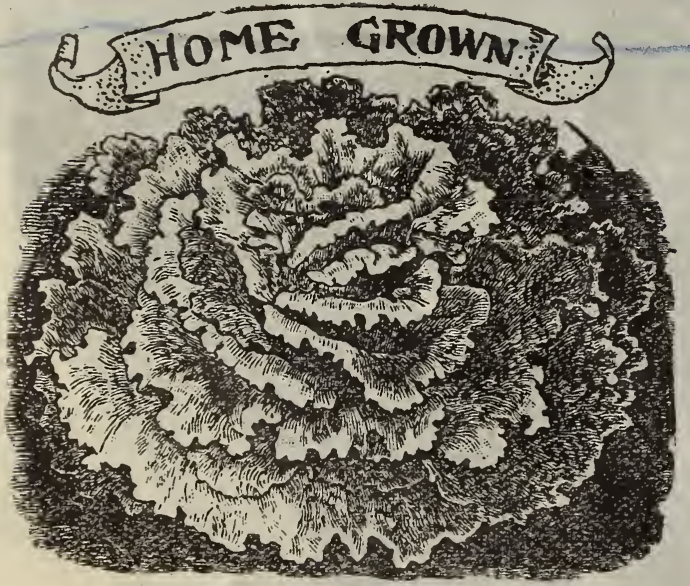

Pri e Head
"Home Grown" Early Curled Silesia-An early clustering variety. May be sown thick and cut while the plants are very young. Very tender, sweet and well flavored. Color light green. Price: Pkt., 5 cents; ounce, 10 cents; one-fourth pound, 25 cents; pound 85 cents.

Black Seeded Simpson "Home Grown"-Large, thin, exceedirgly tender leaf. This is one of the best varieties either for forcing or for early sowing out doors. It is a product of excellent quality and continues a long time in condition for use. Price: Large pkt., 5 cents; ounce, 10 cents; one-fourth pound, 25 cents; pound 85 cents.

Hanson Head Lettuce-A very popular and favored variety, very hardy and will stand extremes of weather, better than any of the other crisp heading varieties. It is a good table quality free from bitterness and remains in excellent condition for use long after it has reached maturity. Price: Pkt., 5 cents; ounce, 10 cents; onefourth pound, 30 cents; pound, $\$ 1.00$.

Prize Head "Home Grown"-Bright green tinged with brownish red, tender, crisp, large loose head. Popular variety for market and garden. Price: Pkt., 5 cents; ounce, 10 cents; one-fourth pound, 25 cents; pound 75 cents.
Northern Seed Co., Valley City, N. D.

Gentlemen-It is with great pleasure I say a word for your garden seeds. My garden was a week or ten days ahead of my neighbors. All of the seeds grew.

As soonas people realize the importance of the Northern grown seeds, our gardens of the nerthwest will be a decided success. Thanking you for prompt service in the past and assuring rou of future orders, I wish you success.

MRS. FRANK COSAND, Coseau, N. D.
Northern Seed Co.. Valley City, N. D.

Gentlemen:- The seeds I purchased of you made a fine growth. I am well satisfied with same.

HENRY KITTS, Belfield, N. D.

....1...... Gred C C.. Valley City, N. D.

Gentlemen:-The seeds I bought from you tested good and $I$ ans, weli pleased with results. You may expect $m$ v patronage hereafter. I shall speak a good word to my neighbors for you. Yours respectfully. JOEL WING, Pinto, N. D. 


\section{ONION SETS}

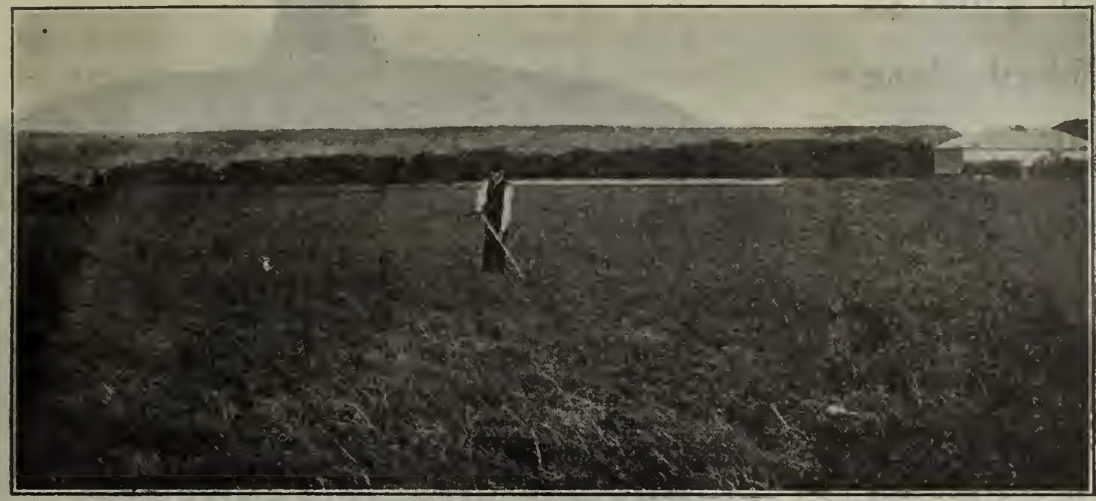

Another year has rolled over our heads, in the seed business that uas proven very conclusively that we were right when we started to produce Northern Seed for Northen people. One thing we are partla ularly proud of is our onion sets. Our yield in some instances run over 500 bushels per acre, of quallty that is unsurpassed. We are getting a great many inquiries from the far Southern country, asking about them. Their superiority having been produced in this Northern country is unquestionable. We quate the following varieties and prices:

White Bottom Sets-Single pound 30 cents, post paid; quart, 30 cents, post paid. By express or freight, per Cwt., $\$ 14.00$; per bushel $\$ 4.50$.

Red Bottom Sets-Single quart or pound 40 cents, postpaid. By express or freight Cwt., \$10.50; bushel, $\$ 3.50$.

Yellow Bottom Sets-Single quart or pound, 25 cents, post paid. By express or freight Cwt. \$10.50; per bushel, $\$ 3.50$. $\$ 4.50$.

Red Top Sets-Single pound or puart, 40 cents, post paid. By express or freight Cwt., \$15.00; bushel,

Multipliers-Single pound or quart, 35 cents, postpaid, By express or freight Cwt., $\$ 13.00$.

All prices on onion sets subject to change without notice, owing to the fluctuations of the market.

Northern Seed Co., Valley City, N. D.

Gentlemen:--I do not think that noney san buy any better seed than we bought from you last spring. You may be sure of an order from us next spring. Wishing you suecess, I remain, Very truly yours

C. J. BIEBER, Linton, N. D.

Northern Seed Company, Valley City, N. D.

Gentlemen:-The seeds I purchased from you last spring have proven to be $O: K$. Every seed came up and the yield, although a dry season, is very good. Yours truly,

E. $A$, FETCHER, Enderlin, N. D.

Nortlern Seed Co., Valley City, N. D.

Dear Sirs:-We were very much pleased with your seed corn and would have had a fine crop if the frost had not come so soon. The ears are from $\&$ to 10 , inches long. We will want some of the same corn next wear.

Respectfully yours,

CHRIST CARLSON, Sheyenne, N. D.

Northern Seed Co., Valley City, N. D.

Gentlemen:-I found your seed all O. K. and up to the standard in every respect. Yours truly,

J. C. IMBODEN, Lisbon, N. D.

Northern Seed Company, Valley City N. D.

Gentlemen:-All the garden seeds I purchased from you last spring grew fine and I have an abundance of all kinds of garden truck.

$$
\text { Very truly, }
$$

NEIL O. LAGARD, Upham, N. D
Northern Seed Company, Valley City N. D.

Gentlemen:-I purchased garden seeds from you last spring and I do not hesitate to say that I was better satiofied with them than any garden seed $I$ have purchased since I came to Dakota, which is 25 years this fall. Please send me your catalog as soon as issued and you win greathy oblige, Yours truly is

JOHN WISE; Gettysburg, S. D.

Northern Seed Company; Valley City N. D.

Dear Sirs:- The seeds I got from you grew fine and 1 well satisled with them. I would not buy any other kind as lonk as I can get the Northern seeds. Please send me your catalog next spring. Yours respectfully, MRS. QLUF OLSÓN, Tioga, N. D.

Northcrn Seed Co., Valley City, N. D.

Sirs:- The seed I ordered last spring from the Northern Seed Company proved a success here. They all did fine. Wishing you success in your business, I remain, Yours, LAURA E. CURRIER, Fairburn, S, D.

Northern Seed Co., Valley City, N. D.

Gentlemen:-The seeds ordered from you last spring were all true to name and I had a splendid stand from all of them. You may look for another order from us next spring. Yours truly.

T. A. WELSH, Garrison, N. D.

Dane Valley, Montana, Aug. 31, 1908. Northern Seed Co., Valley City, N. I

Gentlemen:- I wish to say that the seeds received from rou last spring have been very satisfactory, and every variety has met with our highest expectations.

$$
\text { Very truly yeours, }
$$

A. FRYHLING 


\section{ONIONS}

\section{Onion Seed Produced}

in the Far North, from

Assorted Bulbs, taking

years to Select are

\section{THE BEST}

Culture: (By Prof. Thos. Shaw): Onions may be raised on any good land rich and..fine fairly retentive and drained. Sandy soils dry out too much. Muck soils will grow good crops when drained, but the onions will be a little coarse in texture. It - is greatly important that the land shall not be weedy. The soil should be plowed in the fall

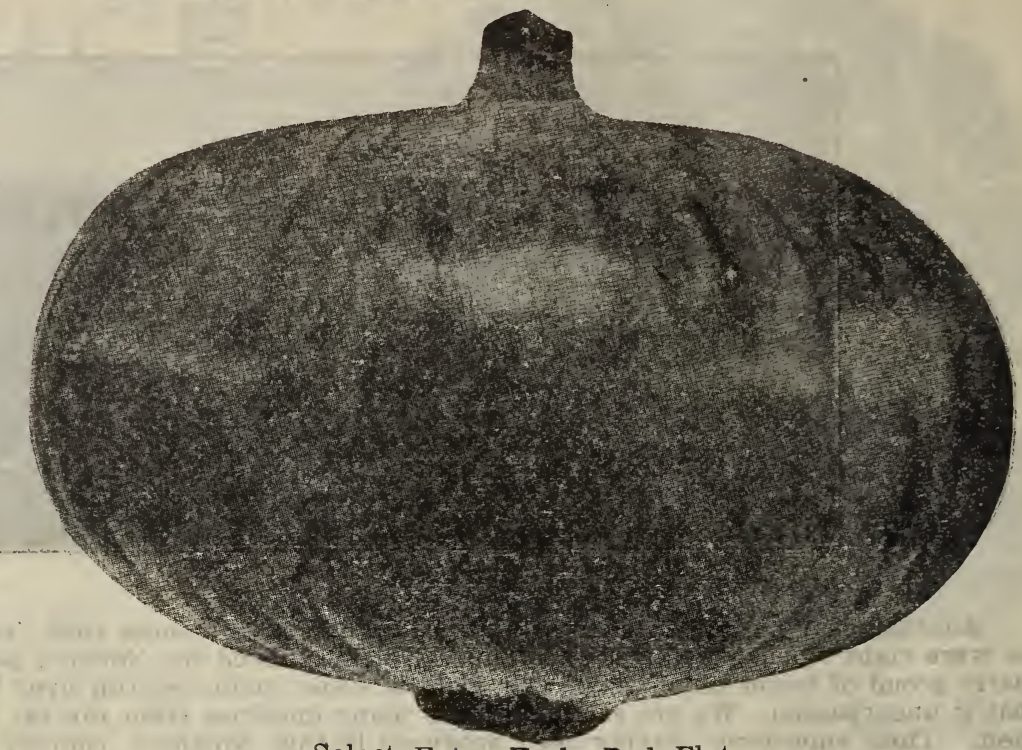

Select Exira Early Red Flat

rather than in the spring to make it firm. If onions follow onions it is better not to plow but simply disk the land or use on it a good harrow after fine manure has been spread upon it. When well ma. nured the same land may be used for several years. The seed should be sown quite early on smooth land but it may be sown later, even until toward the middle of Mav. The rows should be about 15 inches apart, but may vary with the variety, and the seed be buried about an inch with about 20 good. seeds to the foot or 4 or 5 pounds per acre. If sown just right, thinning which is costly, may not be necessary, as the onions stand crowding. The hand cultivator should be used as soon as the onions appear and the crop should be kept clean. They may-be harvested with a rake or onion puller. Onion sets of less size than three-fourths of an inch are planted out in the spring in rows 12 to 15 inches apart, three inches deep and three inches distant in the row.

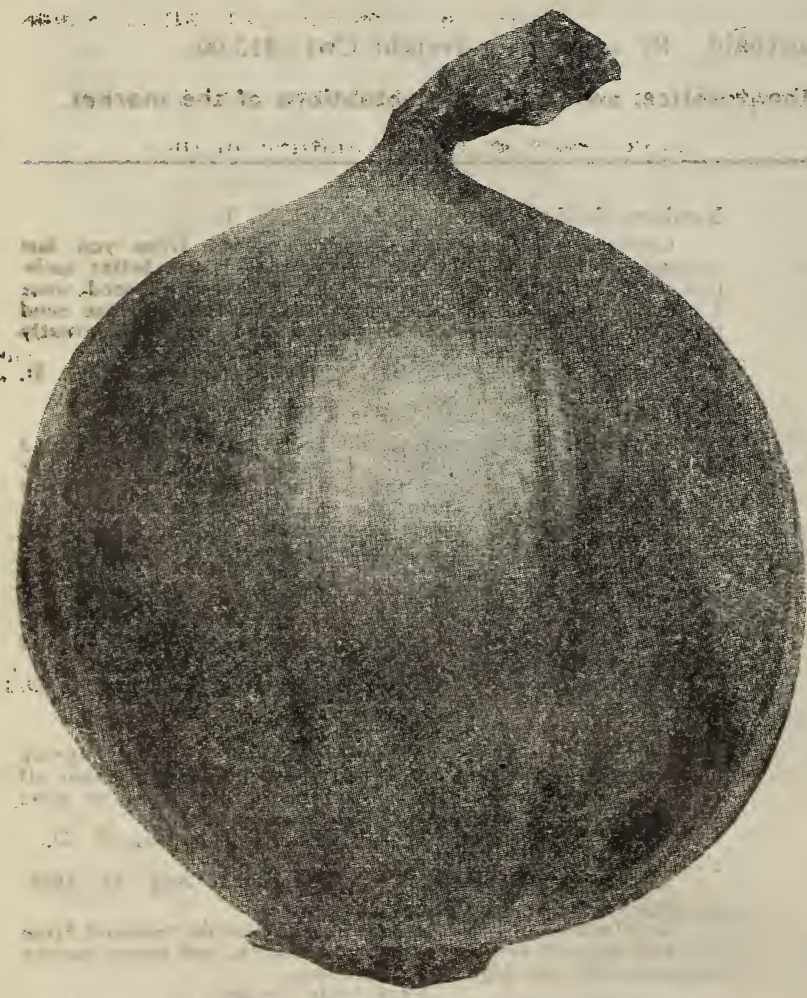

Yellow Danver's Onion

Select Extra Early Red Flat-A flat variety of medium size. Earlier than Red Weath. erfield, fine grained and mild flavor. Especially adapted where seasons are short. Very desirable for early marketing. Our stocks of this variety are exceedingly excellent. Prices: Pkt., 5 cents; ounce, 20 cents; one-fourth pound, 50 cents; one pound, $\$ 1.50$, three to five pounds, $\$ 1.25$ per pound.

Standard Red Weatherfield Onions-Very productive and an excellent keeper. Skin deep purplish, flesh purplish white, often grained. Stronger in flavor than yellow or white onions. This is one of the very best sorts. Price: Pkt. 5 cents; ounce, 15 cents; one-fourth pound, 5.0 cents; one pound, $\$ 1.50$; three to five pounds, $\$ 1.25$ per pound.

Our Wonderful Yellow Globe Danvers-A glove shaped standard variety. Skin light golden brown or pale yellow. Flesh pure white; mild flavor. An excellent winter variety. Price: Pkt., 5 cents; ounce, 15 cents; one-fourth pound, 50 cents; one pound, $\$ 1.25$; three to five pounds, $\$ 1.10$.

Northern Seed Company, Valley City, N. D.

Gentlemen:- The seed I got from you last* spring were very good. All of them came up and everything grew fine. I can recommend your house to any one wanting good, healthy seeds. Yours truly,

A. I. PETERSON, Miott, N. D.

Northern Seed Company, Valley City, N. D.

Dear Sirs:- The seeds which I got from you last spring were fresh and a large per cent germinated, show. ing care in the selecting and curing of them. I intend to order from you again next spring, as I was well pleased with your seerls this year.. Yours truly.

A. G. McKEAN, Topbar, S. D. 


\section{ONIONS CONTINUED}

Our "Home Grown" Early Large Red Globe Onions-Dark red color, globe shaped. This is a fine variety and will please all who grow it.

Price: Pkt., 5 cents; ounce, 20 cents; one-fourth pound, 60 cents; one-half pound, $\$ 1.25$; one pound, $\$ 1.80$; three to five pounds, $\$ 1.60$ per pound.

Clinton, Minn., Oct. 15, 1910

Northern Seed Co., Valley City, N. D.

Gentlemen:-It gives me pleasure to recommend your seeds. The citron and mangels I raised from your seed brought first premiums at our Big Stone County fair.

I pulled up a mangel two weeks ago that was 24 inches long and 6 irlches in diameter, and they are still growing. Not so bad for a dry season we think. Wishing you all success in your seed business, I remain, Respectfully,

FRANK E. MORRILL.

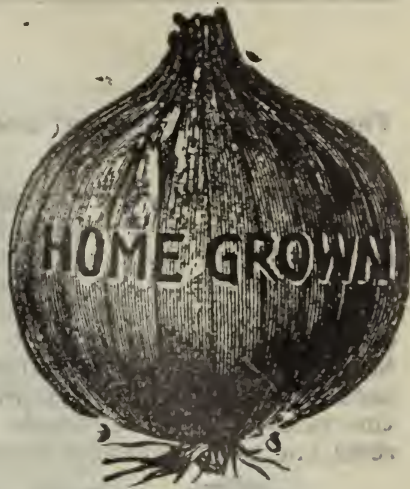

Extra Early Red Globe

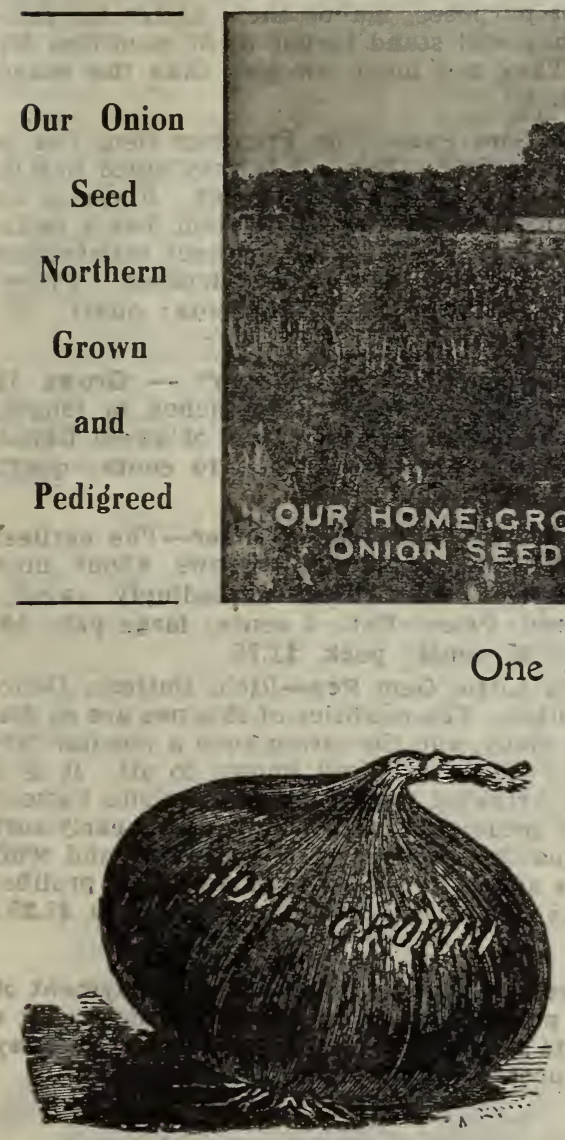

Prize Taker

\section{One of Our Onion Seed Fields}

The Ever Productive Prize Taker-One of the best standard varieties, succeeds everywhere, often yielding over 1200 bushel per acre, gives universal satisfaction for either home or marketing. Onions are large, often 12 to 14 inches around. their keeping quality is unexcelled. The outside skin is of a pale yellow color, while the inside is clear white. Price: Pkt., 5 cents; ounce, 20 cents; one fourth pound, 50 cents; one pound, $\$ 1.50$; three to five pounds, $\$ 1.25$ per pound.

White Pickling Onions - Medium sized bulb. Uniform with clear white skin; mild flavor; a good keeper. Used extensively for pickling purposes. Price: Pkt., 5 cents; ounce, 15 cents; one-fourth pound, 50 cents; one pound, $\$ 2.00$; three to five pounds, $\$ 1.75$ per pound.

Northern Seed Co., Valley City, N. D.

Dear Sirs:-Last spring I bought quite a number of seeds of different kinds, and I can truly say that they are the best garden seed I have ever planted, regardless of where they came from, I am going to plant more seed next spring. and I want your catalog, so I will be sure of getting good seed. If any one doubts this, just write to,

I. B. HATFIELD, Highmore, S. D., Box. 161.

Northern Seed Co., Valley City, N. D.

Gentlemen:-The alfalfa seed I bought from you is all right. It looks to be a good stand so far. Yours truly,

OLE BREDING, Powers Lake, N. D.
Northern Seed Co., Valley City, N. D.

Gentlemen:-I wish to say that -I am very much pleased with the seed I bought from you. I tried different kinds of seed from different companies this spring, but none growed so fast and sure as yours. I shall order my seeds from you in the future.

Yours truly,

ALBERT KAUPANG, Knox, N. D.

Northern Seed Co., Valleÿ, City, N. D.

Dear Sirs:- The seeds you sent me this spring were all $O$. K.. will say $Y$ have not had such a crop for years. I will send you a larger order next spring. D. B. OLSON, 


\section{PEAS}

The Best "Home Grown" Seed Peas Grown in North Dakota, Tested in Our Field Plots and Found Satisfactory.

Culture: (By Prof. Thos. Shaw): Garden peas are of three classes, viz: those having wrinkled ceeds, round smooth seeds, and those having edible pods. The wrinkled sorts, though frequently poscessed of high quality are not so hardy as those that are smooth. Peas will grow well on almost any kind of soll not really poor, but grow best on loam soils' with a strong element of clay in them. The smooth varleties may be sown as soon as the ground can be worked in the spring, but the wrinkled varieties chould not be sown quite so early. By sowing at successive periods the season for peas may be much prolonged. The dwarf varieties now more commonly grown are sown in rows from 24 to 36 inches apart ac cording to the habit of growth. The seed should beburied from three to four inches in the soil and at the rate of about 12 seeds to the foot in the row. The larger sorts have a greater distance between the rows and are frequently sustained with brush or by a wire trellis.

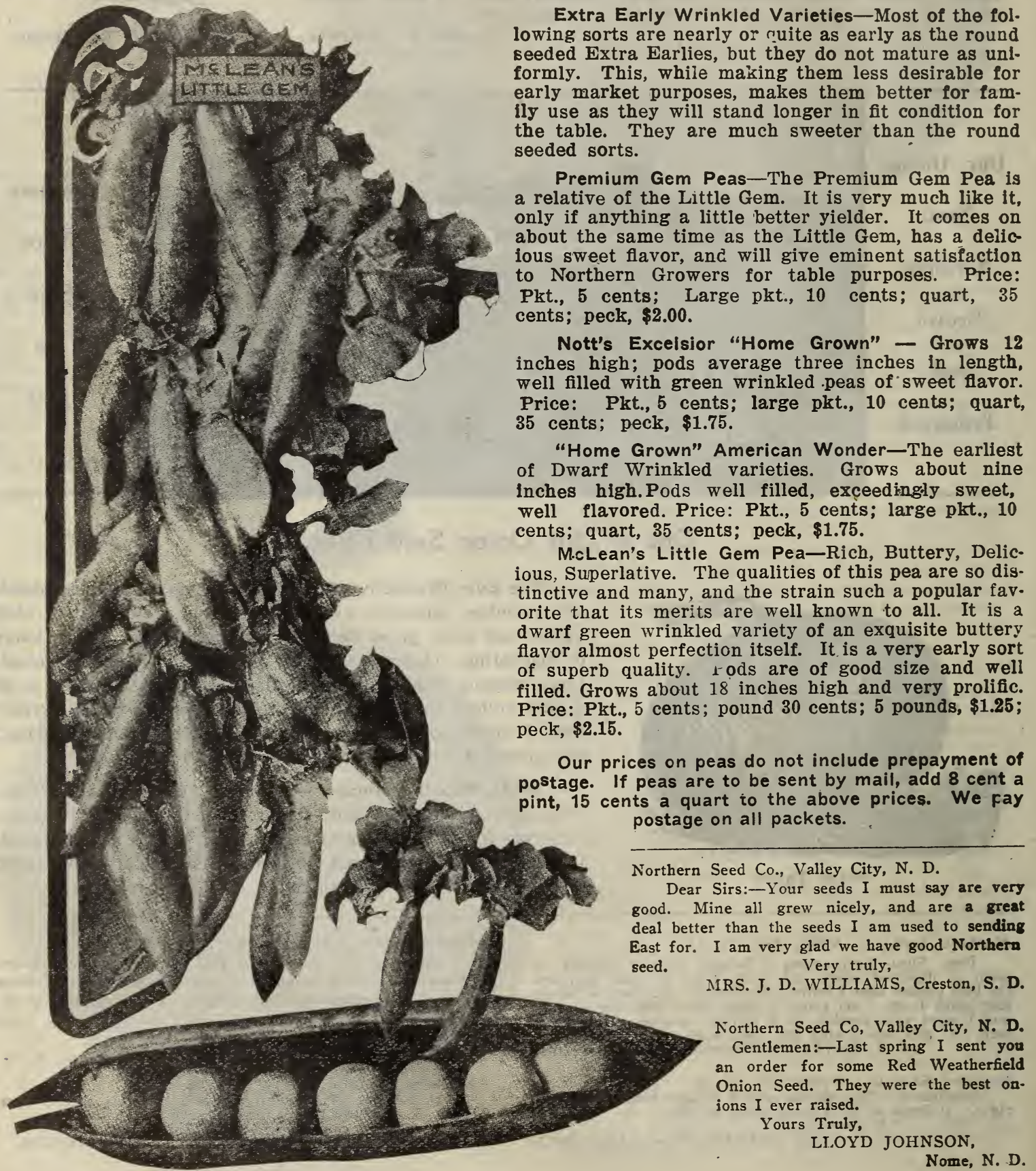




\section{EXTRA EARLY ROUND}

\section{SEEDED VARIETIES}

These sorts are most largely grown by gardeners for the early market. They ripen more uniformly than any other peas and where the stocks have been properly bred and kept rogued from 75 to 80 per cent of the pods can be stripped from the vine at the first picking, enabling the grower to secure the highest prices. Round seeded varieties are not as sweet as the wrinkled sorts, but being more hardy they can be planted earlier and will thrive under severe conditions where other sorts would fail.

EXTRA EARLY-Sold only in sealed packages.) Height, 2 1-2 to 3 feet. Seeds white. One of the most important considerations with a market gardener in choosing an extra early pea, is to secure one that is not only the earliest but that matures its crop uniformly, so that the vines may be stripped in one picking. The "Summit" holdh the record as the earliest and most even in maturity of the white seed. ed varieties. Packet, 5 cents; large packet, 10 cents; quart, 30 cents; one-fourth buhhel $\$ 1.75$; bushel, $\$ 6.50$.

FIRST AND BEST-Height 21 -2 to 3 feet. Standard, white seeded extra early. Vines are vigorous and hardy, bearing from three to seven pods each containing from five to seven medium sized peas of good quality. Price: Pkt., 5 cents; quart 30 cents: one-foourth bushel, $\$ 1.75$; bushel, $\$ 6.00$.

M.IUD S.-Height 2 1-2 to 3 feet. White seeded extra early. Very early and uniform in maturing. A favorite with truckers. Price: Pkt., 5 cents; pint, 20 cents; quart, 30 cents; one-half bushel $\$ 1.75$; bushel $\$ 6.00$.

ALASKA-Height 2 1-2 feet. Very early and exceedingly uniform in maturing its crop. The vines are very productive, bearing four to seven pods which are filled with medium sized bright bluish green peas of good flavor. A great favorite with canners and southern truckers. Price: Pkt, 5 cents; pint, 20 cents; quart, 30 cents; one-fourth bushel, $\$ 1.75 ;$ bushel $\$ 6.00$.

\section{MAIN CROP VARIETIES}

Planted at the same time as the Extra Earlies or Dwarf varieties, these come into bearing when other sorts are gone. For the most part they stand a long time fit for table use, and as a rule they are, except when noted, sweeter than the early sort. The pods are large and they stay longer in fit condition for use.

CHAMPION OF ENGLAND-4 to 5 feet in height. This has been considered the standard main crop or late pea for sum. mer variety has sprung the whole race of green wrinkled peas. The vines are very vigorous and have an abindance of large, well-filled pods. The peas are light green, wrinkled, of fine quality. Hardly any pea is sweeter than this. Price: Large pkt., 6 cents; pint, 15 cents; quart, 25 cents; one-fourth bushel, $\$ 1.50$; bushel, $\$ 5.00$

ABUNDANCE-Height 2 to 21 -2 feet, seeds green wrinkled. As the name implies, the variety is a capital sort for fam ily use, as in addition to its abundance possesses great sweetness and general fine table qualities. The pods are round, 3 to 8 1-2 inches, filled with 6 to 8 peas. It stands fit for use for a long time. Price: Pkt., 5 cents; pint, 20 cents; quart, 30
cents one-fourth bushel, $\$ 1.75$, bushel, $\$ 6.00$

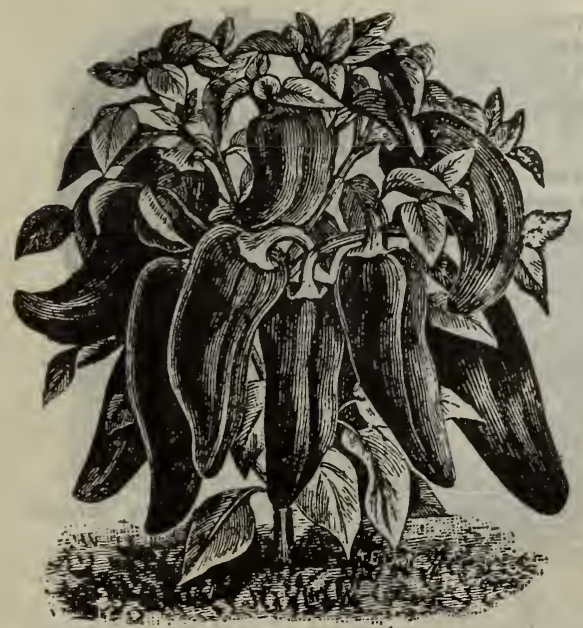

\section{Peppers}

Culture. (By Prof. Thos. Shaw): Peppers are of many varieties. They may be successively grown in any good rich soil. The seed like that of tomatoes is best started under glass. They should not be planted out until the dianger from frost is over. The rows may be three feet apart and the plants two feet for the larger varieties, lout the smaller sorts may be planted more closely. Clean cultivation is essential.

"Home Grown" Bull Nose or Bell Pepper-Large short bell shape. Flesh hard and less pungant than most other va. rieties and one of the earliest variet:es. Desirable for pickling when green. Price: Pkt., 5 cents; ounce, 20 cents; onefourth pound, 60 cents; pound, $\$ 2.00$.

Long Red, Cayenne Pepper-Well known pungent and sharp, firy variety used in pickles, also for feeding birds, and to make pepper sauce. Price: One-fourth pound 40 cents: ounce, 15 cents; pkt., 5 cents.

Northern Seed Company, Valley City, N. D.

Gentlemen:-I am well pleased with the seed I ot from you. All the seed grew and is maturing -nicely. You may expect my order the com. ing spring.
Respectfully yours,
MRS. LOVILA SHOEMACKER, Lamoine, N. D. 


\section{PARSLEY}

Culture. (By Prof. Thos. Shaw): This plant will grow in any kind of good soil. For winter and early spring use it is grown in hot houses, but may also be grown in boxes like house plants. When sown outdoors the seed is buried one to one and a half inches, and the rows are 18 to 20 inches distant. The plants are thinned while yet small and to the distance of not less than six inches. The leaves are picked from time to time and may be obtained come of the plants with the green in winter by lifting earth around them and keeping them amid the light and shielded from frost.
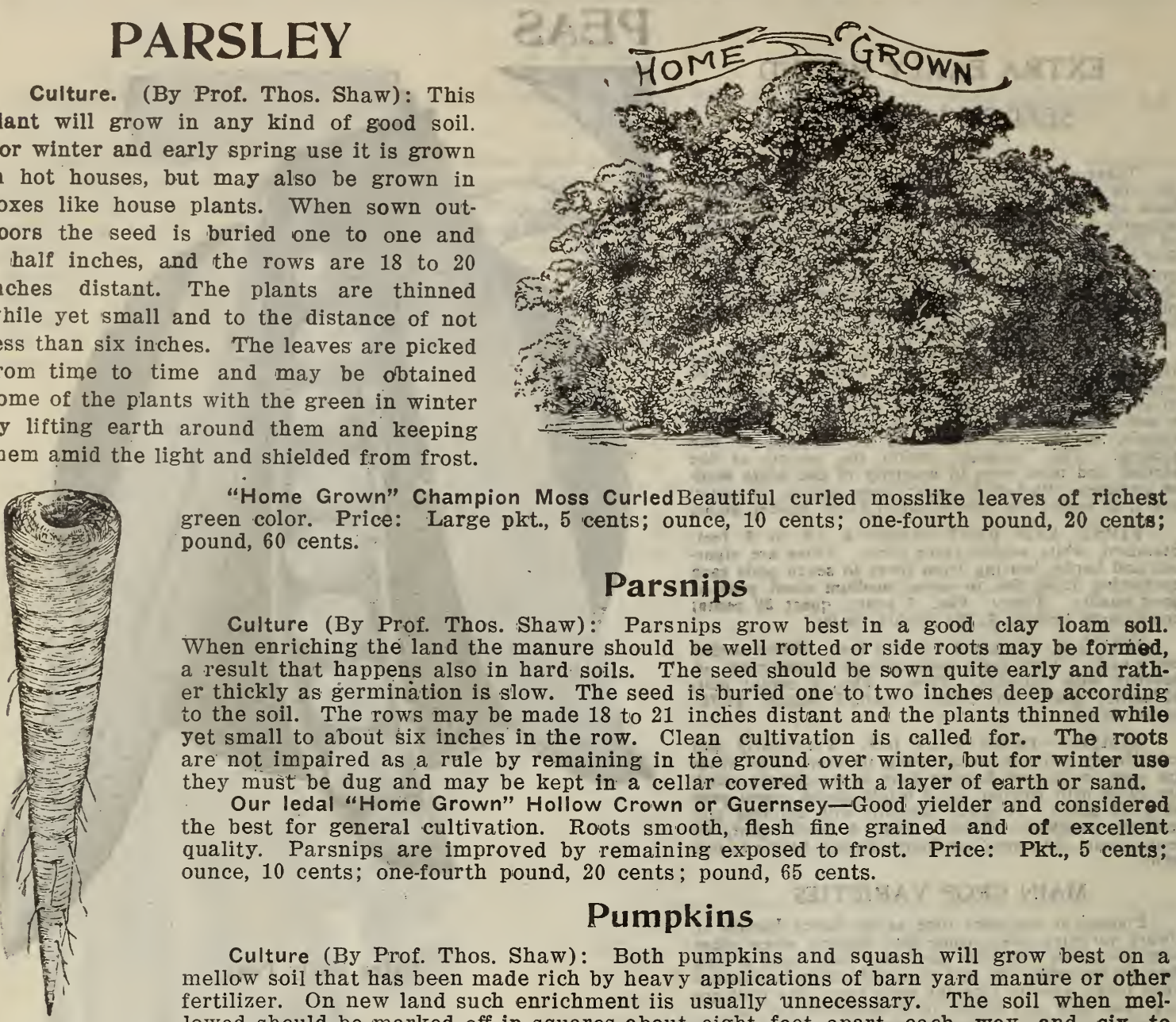

"Home Grown" Champion Moss CurledBeautiful curled mosslike leaves of richest green color. Price: Large pkt., 5 cents; ounce, 10 cents; one-fourth pound, 20 cents; pound, 60 cents.

\section{Parsnips}

Culture (By Prof. Thos. Shaw): Parsnips grow best in a good clay loam soll. When enriching the land the manure should be well rotted or side roots may be formed, a result that happens also in hard soils. The seed should be sown quite early and rather thickly as germination is slow. The seed is buried one to two inches deep according to the soil. The rows may be made 18 to 21 inches distant and the plants thinned while yet small to about six inches in the row. Clean cultivation is called for. The roots are not impaired as a rule by remaining in the ground over winter, but for winter use they must be dug and may be kept in a cellar covered with a layer of earth or sand.

Our ledal "Home Grown" Hollow Crown or Guernsey-Good yielder and considered the best for general cultivation. Roots smooth, flesh fine grained and of excellent quality. Parsnips are improved by remaining exposed to frost. Price: Pkt., 5 cents; ounce, 10 cents; one-fourth pound, 20 cents; pound, 65 cents.

\section{Pumpkins}

Culture (By Prof. Thos. Shaw): Both pumpkins and squash will grow best on a mellow soil that has been made rich by heav y applications of barn yard manure or other fertilizer. On new land such enrichment iis usually unnecessary. The soil when mellowed should be marked off in squares about eight feet apart each way and six to eight seeds planted in a hill, but not so early as to incur any hazard from frost. The flat hills should be well mixed with barn manure. The plants should be reduced to two or at the most three in a hill. The ground should be kept well stirred on the surface and clean. For stock feeding, pumpkins and squashes may be grown in the same way, but more frequently they are grown in corn, the seed being planted at the same time. It may be necessary to keep the young plants dusted with Paris Green and land plaster to protect them from the striped beetle.

Our "Home Grown" Connecticut Field Pumpkin-Grows very large; of an orange yellow color. Is easily grown for stock feeding purposes, but also used for making pies. Very productive. Price: Large pkt., 5 cents; ounce, 10 cents; one-fourth pound, 15 cents; pound, 35 cents.

Sugar or New England Pie Pumpkin-This is a small, very sweet fine garden variety. Skin is deep orange, flesh rich yellow; the very best quality. Excellent for pies. Price: Pkt., 5 cents; ounce 10 cents; one-fourth pound, 20 cents; pound, 60 cents.

Northern Seed Company, Valley City, N .D.

Gentlemen:-We were pleased with the seed ordered from you last spring, and the product. Not only were the seeds good but, the varieties and seed were adapted to our locality. We will give you a larger order next spring.

$$
\text { Yours very truly, }
$$

C. M. 'STINCHCOMB, Donnybrook, N. D.

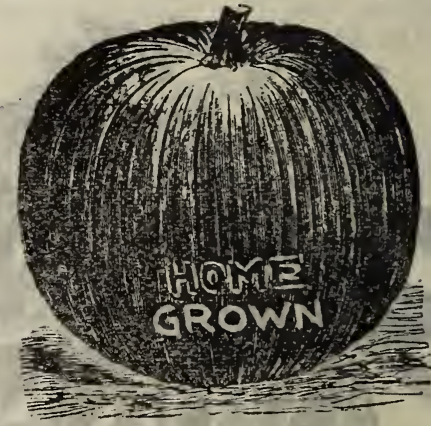

Sugar
Northern Seed Co., Valley City, N. D.

Dear Sirs:-I wish to say that I am well pleased with the Early Ohio Seed Potatoes I ordered from you last spring. Yours truly,

A. F. BELCHER, Sykeston, N. D. Northern Seed Co.. Valley City N. D.

Gentlemen: The seeds etc., received and most of them planted. I expect a lig yield. The Cauliflower and Cabbage are large enough to transplant

RAY CORTLANDT, Hettinger Co., N. D.
Northern Seed Co., Valley City, N. D:

Gentlemen:-The seeds you sent me last spring turned out satisfactory, they came nicely and are doing fine. Yours truly.

PETER ROTHI, Tagus, N. D.

Northern Seed Co., Valley City N. D.

Dear Sirs: I have patronized your seed house for sev. eral years and always got the best of service and unexcelled quality. Please send me your catalog for 1911 . OSCAR WILBER, Washington Co., Oregon. 


\section{RADISH}

\section{The Secret in Growing Good Radishes}

Consists chiefly in the observance, on the part of the grower, of three points. First, they should be grown on light quick soil. Second, they should be given plenty of water, and last, but not by any means least the right kind of seed should be sown. Radishes grow very quickly and if not supplied with sufficient moisture are likely to be pithy.

\section{EARLY TURNIP RADISHES}

EARLY WHITE TURNIP RADISH-Matures in about 30 days; continues good for tabble use a long time after reaching edible size. Round in shape; has small top; skin pure white, waxy flesh, mild flavor. Generally used for outdoor sowing. Price: Pkt., 5 cents; ounce, 10 cents; one-fourth pound, 20 cents; pound 60 cents.

RE-SELECTED EXTRA EARLY SCARLET TURNIP-Turnip shape; deep red color; small top. Very desirable for out door planting as well as forcing. A very early variety. Very popular for its rich color, crisp and tender flesh. Price: Large pkt., 5 ecnts; ounce 10 cents; one-fourth pound, 20 cents; pound, 60 cents.

EARLY SCARLET GLOBE-Fine for forcing or open ground. The shape is a little longer than round and the color, which it holds long after pulling, is very brilliant and attractive. Has a small top and is very early, being fit to pull as soon as Non Plus Ultra, but is much larger when matured. The flesh is white and tender making it desirable for gardeners whose markets demand a large early forcing radish. Price: Large pkt,. 5 cents; ounce, 10 cents; 'one-fourth pound; 25 cents; pound, 75 cents.

NEW TURNIP RRADISH-This is a decidedly unique novelty in radishes. It is very early, maturing about twenty days from the time of sowing. It is globe-shaped; the tops are short, which makes it valuable for growing under glass. The flesh is very crisp, solid and of mild flavor. The ground color is pure white, striped horizontally with bright scarlet. Price: Large pkt., 5 cents; ounce, 10 cents; one-fourth pound, 30 cents; pound, 95 cents.

Culture: Radishes will grow on any kind of mellow soil, but do much the best on new land. The seed of spring radishes may be sown from early spring until early summer, the successive sowing leav. ing two to three weeks between them. The rows need not be further apart than will admit of easy hard hoeing or hand cultivating. In some instances the seed is sown in rows between the rows of carrots,

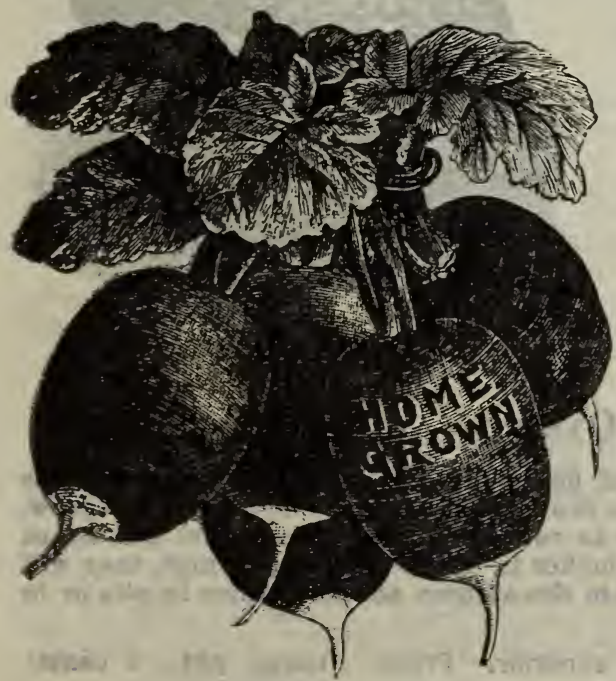

French Breakfast

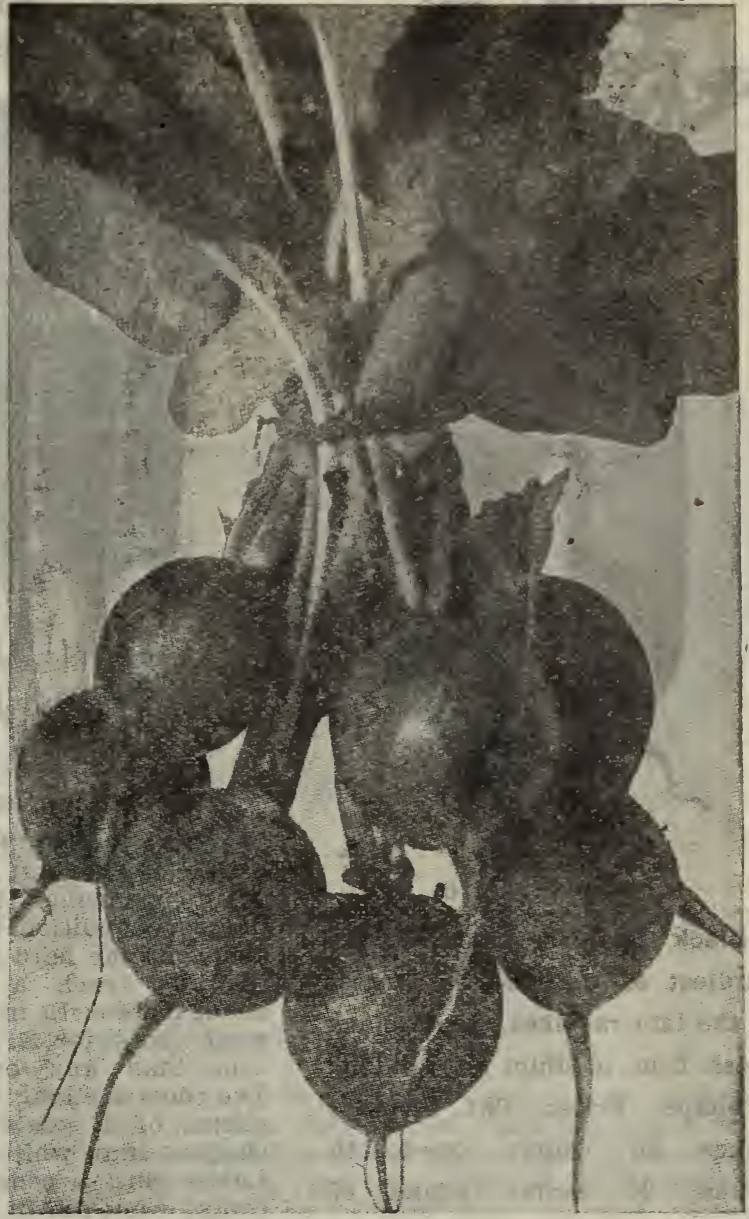

Early Scarlet Turnip Radish beets and parsnips, as the radishes are removed before they impair the other crops. Nearly all varieties are ready for use within a few weeks of the time of sowing the seed. Unless sown very thickly, thinning is not much called for. Winter radishes are sown in June or July in rows 18 to 24 inches apart. It is better to sow radishes on land manured the previous year than on newly manured land.

\section{Radishes}

Early Olive Shaped Radishes- French Breakfast.-A great favorite. Beautiful, bright scarlet, with pure white tip. Oblong in shape, medium size, makes rapid growth. It is a fine table variety on account of its excellent quality and attractive appearance. Fine for open ground or forcing. Large Pkt., 5 cents; ounce, 10 cents; one-fourth pound, 25 cents; pound, 70 cents.

Early Scarlet Olive-A very useful variety. Matures in 25 days; color, bright scarlet; flesh', crisp and tender. Best adapted for main crop. Large pkt., 5 cents; ounce 10 cents; one-fourth pound, 20 cents; pound 60 cents.

The Very Best Radish for the Northwest 


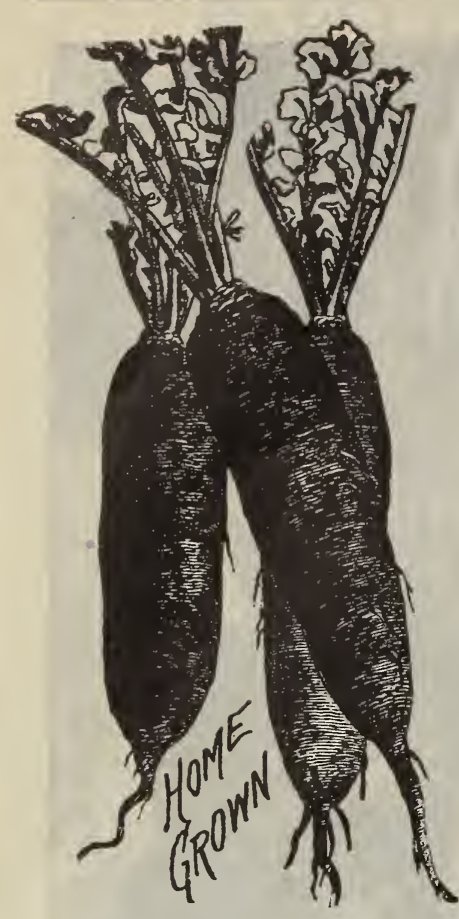

Black Spanish

Black Spanish-One of the hardiest as well as the largest of the late radishes. Roots black Flesh firm, medium size, oblong in shape. Price: Pkt., 5 cents; ounce, 10 cents; one-fourth pound, 20 cents; pound 65 cents.

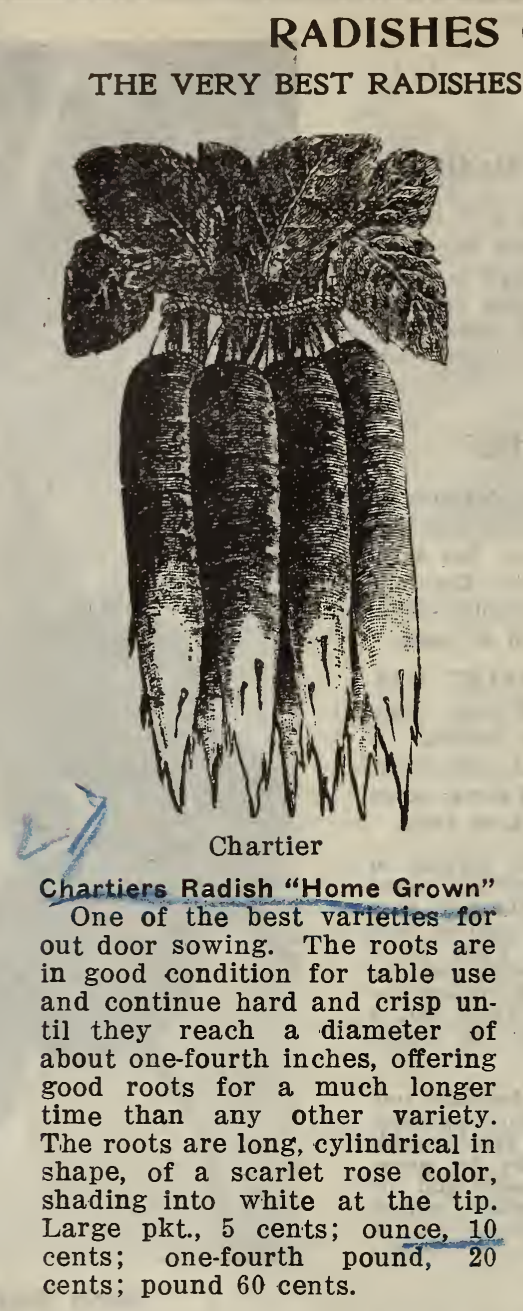

\section{Continued}

FOR THE NORTHWEST

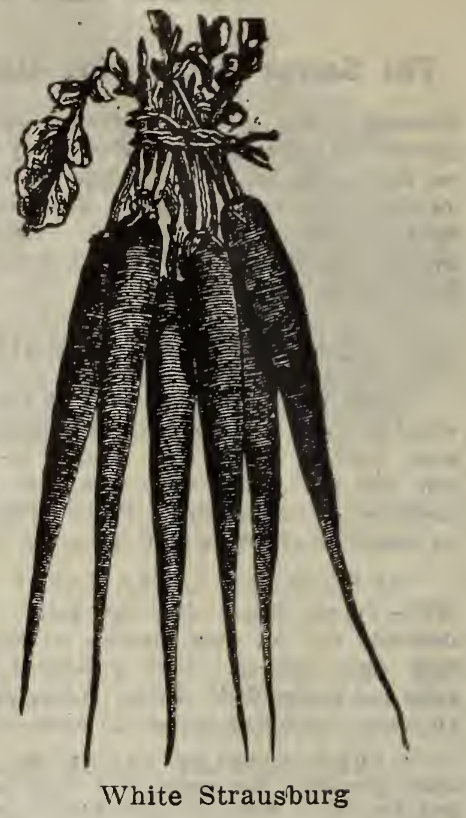

White Strausburg-Good for use when comparatively small; continues crisp and tender un. til matured, when the roots are four or five inches long. This is one of the best large summer sorts. Price: Large pkt., 5 cents, ounce, 10 cents; onefourth pound, 20 cents; pound 60 cents.

\section{SQUASH}

Early Summer Crookneck, "Home Grown"-The fruit of the true crook neck type if of a light golden color. When matured it is about one foot long. The most popular variety for home and market use. Early and prolific. Price: Large pkt., 5 cents; ounce, 15 cents; one-fourth pound, 30 cents; pound $\$ 1.00$.

Our "Home Grown" Improved Hubbard Squash-Is one of the best of the winter varieties. Flesh bright orange yellow, very dry, sweet and rich flavor. A good keeper. Boils or bakes exceedingly dry and is considered by many to be as good as the sweet potato.

The peculiarities of wartiness and color of shell are largely determined by the soil in which the squashes are raised. Price: Large pkt., 5 cents; ounce, 15 cents; onefourth pound, 30 cents; pound, $\$ 1.00$.

\section{Salsify or Vegetable Oyster}

Culture (By Prof. Thos. Shaw:) This plant has a long and fleshy taproot and grasslike leaves. The plants will grow on any good soil. In habit they are much like the parsnip, and the directions for grow. ing them are much the same. The seed should be sown early in rows 15 to 18 inches apart and about one inch deep. The plants are thinned to from three to four inches in the row. Like parsnips, they will live through the winter, but it is usually better to dig the roots in the autumn and keep them in pits or in the cellar with a slight covering of earth.

Mammoth Sandwich Islands, Home Grown-Large and superior. Price: Large pkt., 5 cents; ounce, 15 cents; one-fourth pound, 35 cents; pound 95 cents. 


\section{SUNFLOWER}

Culture: Sunflowers are grown chiefly for the seeds, but in some instances the whole plant is made into ensilage. The seeds furnish good food for live stock, especially for poultry and when grownIn a large way oil is expressed from them. They will grow on any good soil and even under dry conditions. The seed is commonly planted in rows, not closer than 36 inches and so that the seeds will not be more than six inches apart in the row and from one to three inches deep, according to the soil. While the plants are yet small the cultivation ought to begin. When less than six inches high they should be thinned to not less than one to two feet in the line of the row according to the variety of the plants.

Mammoth Russian-The best egg-producing food known for poultry, can be raised cheaper than corn.

Single heads measure fifteen to twenty-two inches in diameter, and contain an immense amount of seed, which is highly valued by all farmers and poultry breeders who have tried it.

If you keep only a pair of fowls get a pound of this seed Just for a trial and be convinced.

It contains the shell to make eggs. It gives the fowls a bright, lustrous plumage. It keeps ther in a strong, healthy condition. It makes eggs hatch more vigorous chicks. It makes them more vigorous than if fed on any other food.

It prevents roup, it stops egg eating, it stops feather picking. It is a heavier cropper on almost any soll. It can be sown from early spring up to July. It is also good food for cattle and horses. It is used as a medical herb. It keeps disease away if planted around the house. It is fattening to either poultry or cattle. Its strong, thick stalk can be used as fuel. In fact it is the most wonderful, cheapest and best poultry food known.

Three pounds will sow one acre and the average yield is 100 bushels to the acre. Price: Pkt., 5 cents; ounce; 10 cents; pound, 20 cents, post paid; by express or freight, 10 pounds 60 cents.

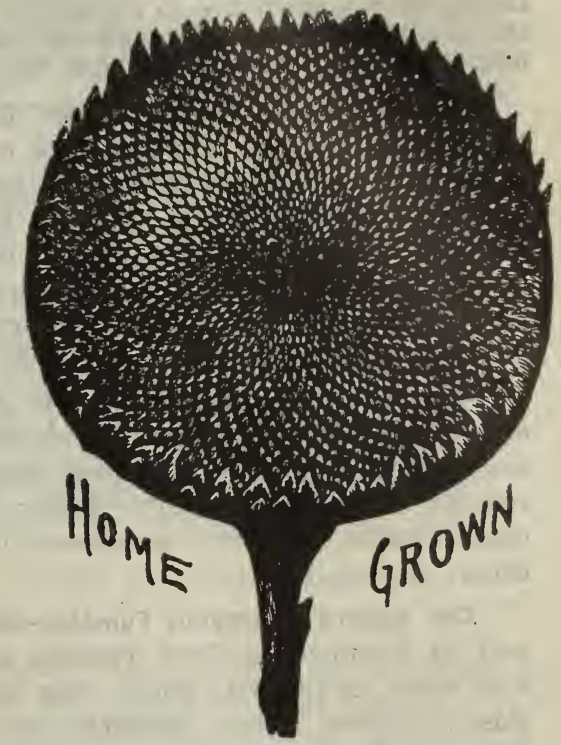

\section{Musk Mellons and Citrons}

Culture (By Prof. Thos. Shaw): Melons and Citron are best grown on a sandy loam soll, but may be sown on any soil, warm, friable and moist. When the land has been plowed and smoothed it is marked off in rows both ways six feet apart. At the intersection of the tracks some earth is rencived a chovelful of manure is mixed in the cavity and the removed earth is replaced. From 10 to 12 seeds are burled in each hill one inch deep or a little more. The seed should be planted about the corn planting eeason. The ground should be kept clean and stirred frequently about the plants not more than three trong ones being left in a hill. After the main vines have extended several feet, pinching off the ends will encourage the setting of fruit on the laterals. A piece of board put under the melons when they are well formed will result in better fruit.

Extra Early Hackensack-Flesh green, delicious, juicy and sweet; medium size, especially adapted to Northern climate. Price: Pkt., 5 cents; ounce, 10 cents; one-fourth pound, 30 cents; pound, \$1.00.

\section{Water Mellons}

Culture (By Prof. Thos. Shaw): Water Melons and Citrons may be grown by practically the same methods. They do best on a loose soll well stored with humus. The seeds are planted in low hills, made in squares about eight feet distant. From 6 to 10 seeds may be planted in a hill and when but a few inches grown, only three strong plants should be left in a hill. The earth should be kept loose and dean near the surface by cultivation. Well decayed fertilizer mixed in the earth in the hills will be a sreat help. The vines should not be pinched back as in the case with musk mellons and cucumbers.

"Home Grown" Pinny's Extra Early-Oblong in shape, medium size. Flesh bright red and $\nabla e r y$ aweet. Seeds white, skin mottled white and green. Vines very productive. An excellent variety lor market use in northern latitudes. Price: Pkt., 5 cents; ounce, 10 cents; one-fourth pound, 60 cents.

\section{Citrons}

Red Seeded Citron for Preserving-Not good for eating raw, but makes an excellent transparent preserve of a peculiar fine flavor; matures early and will keep in storage several months. Price: Pkt., 5 cents; ounce, 10 cents; one-fourth pound, 20 cents; pound, 70 cents. Postpaid.

Northern Seed Co., Valley City, N. D.

Gentlemen:-I received the timothy seed you shipped me, last spring and sowed it. I certainly got a nice stand. The corn I got from you came up good too. I am satisfied that "Home Grown" seed is the best for North Dakota. Yours truly,
Northern Seed Co., Valley City, N. D.

Gentlemen:-We were well pleased with the seed that we purchased from you last spring. Our second order for sweet corn was rather late, still we will have fair returns from it. Turnips, rutabagas and stock carrots did especially from it. Turnips, rutabagas
fine.

Ó. W. BABCOCK, Roscoe, S .D. 


\section{TOMATOES}

\section{SELECTED LIST OF STANDARD RED TOMATOES}

Culture (By Prof. Thos. Shaw): Tomatoes may be grown on a wide variety of soils but do best on a rich sandy loam with a retentive subsoil. The plants should be started in hot beds or in boxes in the house to insure ripening, in Northern climates. The seed should be buried to about an inch in very rich soil. When the plants have made their second leaves, they should be transplanted, and again with wider spacing to make them stocky and strong when planted out, which should be as soon as the danger of frost is past. "A southern slope will hasten the ripening. The land will bear rich manuring. The plants should be put down five to six inches in the soil and not less than four feet distant each way, except in the small varieties. Thorough cultivation is called for. When much of the fruit has set, the strons branches should be clipped back several inches to aid in developing the fruit.

Our Re-selected "Home Grown" EarlianaIs an excellent early tomato, large in size, of a beautiful color, has few cells and nearly seedless; very solid.. A vigorous grower, a prodigious bearer, yielding its fruit until frost comes. Price: Pkt., 5 cents; one-half ounce, 25 cents; ounce, 40 cents; one-fourth pound, \$1.25; pound, \$3.25.

Our Matchless "Home Grown" Acme Tomato-Is a very popular early variety,smooth and round; purple fruit. Ripens early in the season; fruit rather soft. Price: Pkt., 5 cents; ounce, 20 cents; one-fourth pound, 60 cents; pound, $\$ 2.25$.

Our Superb Champion Tomato-Sometimes sold by seedmen as Tree Tomato, stands up well when loaded with fruit. May be planted close together. Very desirable for summer gardens. Extra early; smooth and attractive. Skin is tough, flesh solid, has a good flavor. Price: Pkt., 5 cents; ounce, 20 cents; onefourth pound, 75 cents; pound, $\$ 2.25$.

Yellow Cherry-Fruits are of a light lemon. yellow, about half an inch in diameter, bears early and freely until frost. Price. Pkt., 5. cents; ounce, 20 cents; one-fourth pound, 60 cents; pound, $\$ 2.00$ postpaid.

\section{SPECIAL NOTICE FOR TOMATO SEED.}

Fish's North Dakota July Tomato-This tomato has been bred and selected by Rev. S. E. Fish, pastor of the Getchell Congregational church, Valley City, N. D., for the past six years. For the past five years he has been able to pick ripe tomatoes before August 1st, hence the name. Anyone wishing to try this extraordinary strain, we price them at 20 seeds for 10 cents, post paid. Our stock of this seed is limited and orders should be sent in early. Price: 20 seeds for 10 cents, post paid.

\section{Ground Cherries}

Golden Husk Tomato or Ground Cherry-Fine for making pies or delicious for preserves. The vines cover the ground and yield abundantly. The fruit is' enclosed in a husk. Price: Pkt., 5 cents; ounce, 25 cents; one-fourth pound, 85 cents; one pound, $\$ 3.00$. Post paid.

Northern Seed Co., Valley City N. D.

Gentlemen: I have used your. seeds for the past three years and they have given perfect satisfaction in every case. There were more seeds in your packets than any firm $I$ ever dealt with. MRS. ETTA NEWMAN, Montrail Co., N. D.

\section{Northern Seed Co., Valley City N. D.}

Gentlemen: When my neighbors ask me how I have such a fine garden I tell them I used "Home Grown" seed from the Northern Seed Company, Valley City, N. D.

Yours truly, MISS ADA WELLS, Dawson Co., Mont.

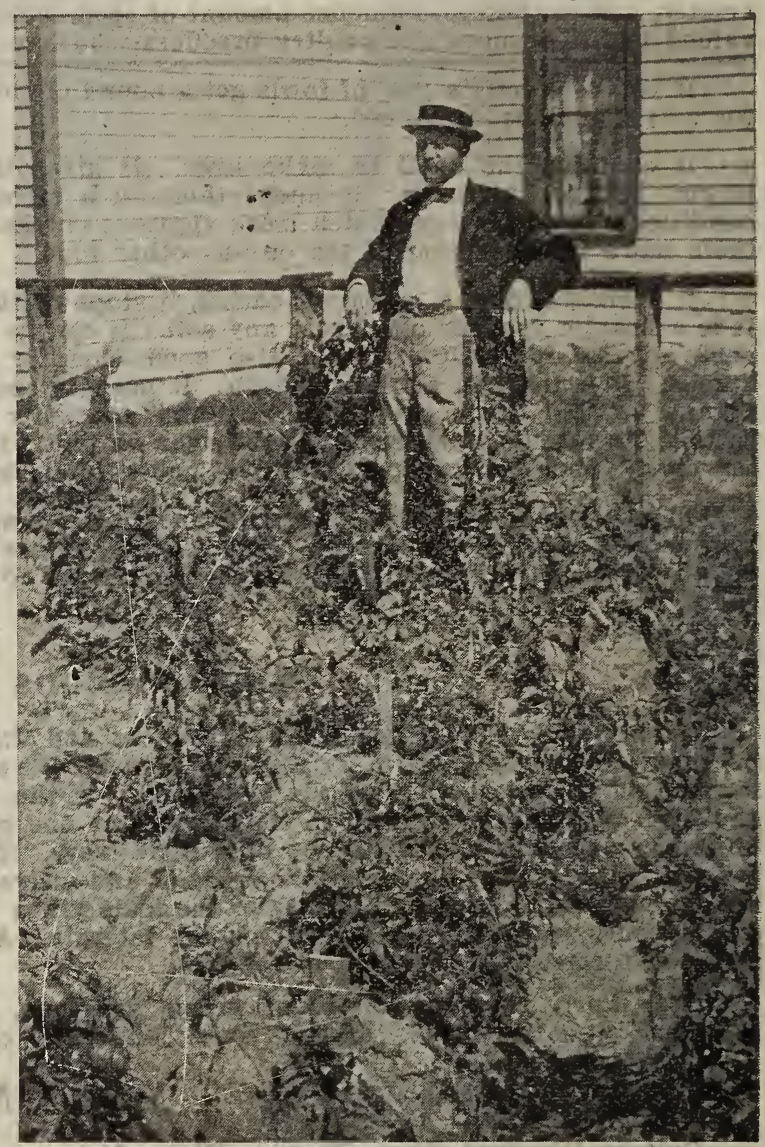
Prof.J. B. Meyer of the State Normal School, and his potato patch 


\section{RELIABLE TURNIPS AND RUTABAGAS}

\section{Turnips}

Culture (By Prof. Thos. Shaw): Turnips grow the best in a friable soil, preferably a sandy loam. They also grow best in cool weather and should grow rapidly to be possessed of highest quality for table use. For early table use, the seed of some quick maturing variety is sown as soon as the ground can be worked in the spring on well prepared land, free from fresh manure, and in rows about 15 inches apart, burying the seed from one to two inches according to soil. The plants are thinned to about three inches in the row. For stock feeding the seed is frequently mixed in with the grain, using one to two pounds of seed per acre. But more commonly they are grown in rows about 24 to 30 inches apart, and on land well manured and preferably buried the previous autumn. The seed is sown on the level or in drills raised a little and each instance with suitable machines. The seed is best sown from about June 1st to June 15th. Two pounds per acre will suffice. Cultivation should be prompt and frequent. When about three inches high the plants are thinned to 8 to 12 inches in the row. Rutabagas which are much more valuable than turnips are similarly grown. ( .

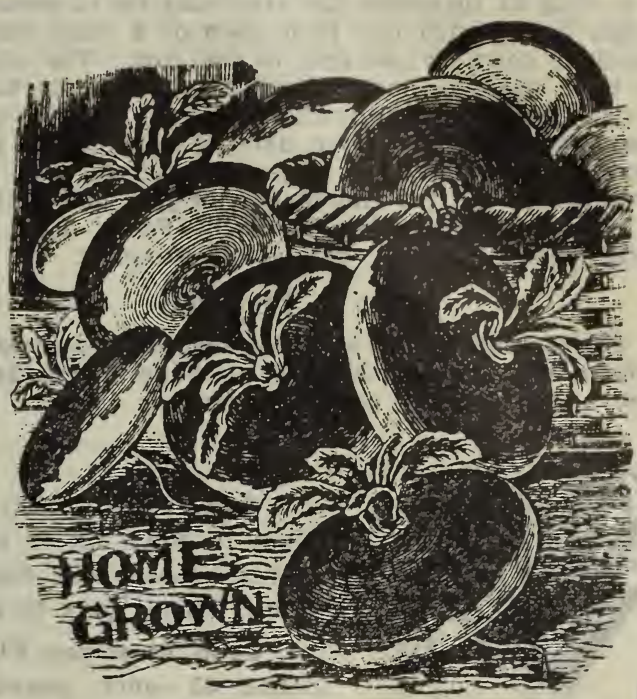

Purple Top Steak Leaf

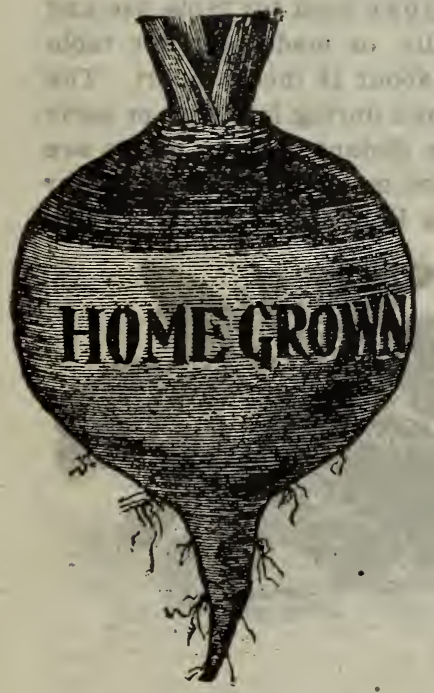

Rutabaga

Purple Top Strap Leaf Turnips-A general favorite and more extensively grown than any other turnip. Will form good sized bulbs in seven or eight weeks. Clear purple above ground, white below. Flesh white, sweet and tender. Price: Pkt., 5 cents; ounce, 10 cents; one-fourth pound, 30 cents; pound, 60 cents.

"Home Grown" Early White Egg Turnip-Pure white, very handsome, well known. Excellent for early or late crop. A quick grower and good keeper. Flesh firm and mild. Price: Large pkt., 5 cents; ounce, 10 cents; one-fourth pound, 30 cents; pound, $\$ 1.00$.

Northern Seed Company, Valley City, N. D.

Gentlemen:-The seed I got from you last spring was free from foul seed and very good. I got an excellent stand and any one wanting good seed could do on better than to et them from your company.

Respectfully yours,

C. H. HOUSE, Granville, N. D.

Gentlemen:-The seed I bought from you last spring was all $O$. $K$. and I wish to get some more nert spring. Yours very truly, ANDREW HOLMQUIST, Ambrose, N. D.

\section{Rutabagas}

Improved American Purpletop-Of uniform shape, fine quality. Grows to a large size; skin smooth, flesh beautiful and fine grained, sweet and tender, excellent flavor, tops small and necks short. Price: Large pkt., 5 cents; ounce, 10 cents; one-fourth pound, 20 cents; pound, 50 cents.

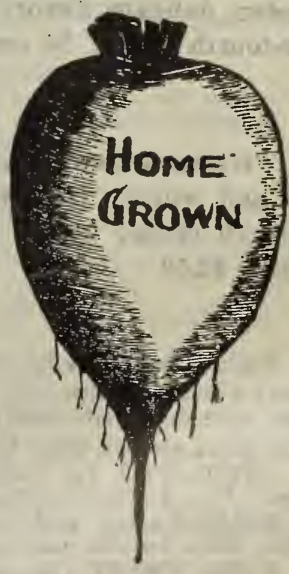

White Egg
Northern Seed Co., Valley City, N. D.

Dear Sirs:-I am perfectly satisfied with the seeds I received from you this spring. Every seed seemed to be fertile and the vegetables are of a very fine flavor, the best we have ever eaten. Yours very respectfully,

MRS. JOSEPH KIMAS, Carrington, N. D.
Dear Sirs:-I was more than pleased with the seeds I received from you lasts pring. I think the Northern Grown- Seeds will grow better here, in North Dakota, than the Eastern Grown seeds, at least they did for me. I also wish to receive your new catalog. Yours truly,

MRS. WM. JENSEN, Newport, N. B. 


\section{Miscellaneous $==$ SPINACH}

Culture (By Prof. Thos.. Shaw): This plant will grow in any good and rich soil. The seed may be sown in cold frames, in hot beds, or in the garden, according to the season when the plants are wanted. By sowing at intervals the crop may be in season for several months. When the seed is sown in the garden it is buried one inch deep or a little more, in rows 12 inches apart, not less than say 40 seeds should be sown. to the foot in the row. The crop may or may not need more or less thinning according to the stand of the plants. With good cultivation the crop may be ready for use in about six weeks from the date of sowing the seed. It is frequently grown between crops of cabbage and potatoes. It is harvested by cutting the plants off just below the surface.

Savory or Bloomdale Spinach-Price: Pkt., 5 cents; onefourth pound, 10 cents; one pound, 30 cents.

\section{Thyme}

Leaves and shoots used for seasoning purposes. Tea is also made of the leaves, which is used as a remedy for headache. Price: Pkt., 5 cents; ounce, 30 cents.
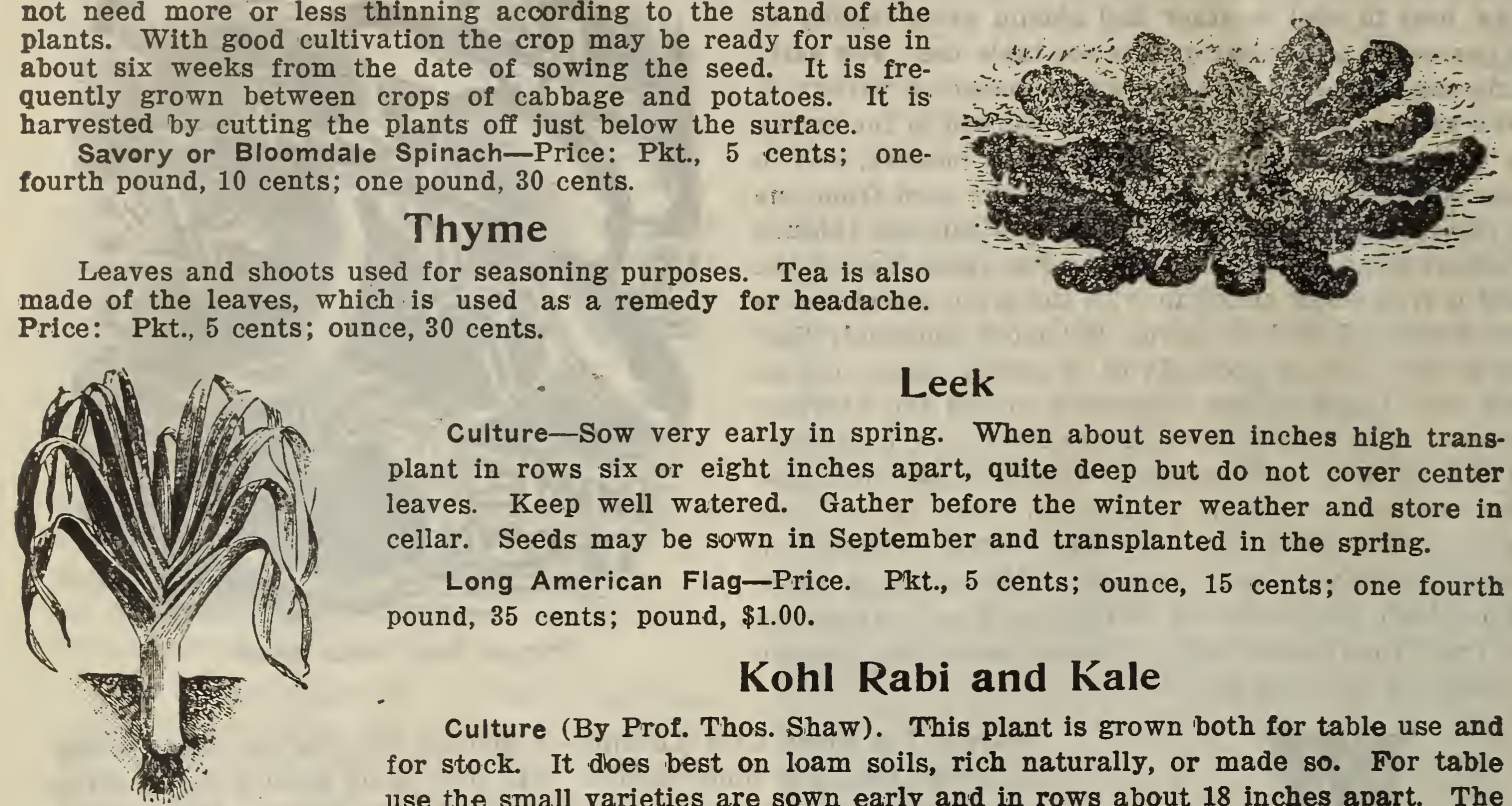

plants are thinned to about plants are thinned to about six inches. For live stock the seed is sown in rows during late May or eariy thinned to 8 to 10 inches in the row. Bulbs which form above the ground are much prized as food for stock. Kale which is used for greens may be grown in much the same way as Kohl Rabi.

\section{Kale}

Makes excellent greens for winter use. Leaves bright green tender, delicate flavor. Price: Pkt., 5 cents; ounce, 10 cents; one-fourth pound, 25 cents; pound, 60 cents.

\section{Kohl Rabi}

"Home Grown" Early White Vienna-Small bulb. Flesh tender and white. Highly esteemed by market gardeners. Price: Pkt., 10 cents; ounce, 25 cents; one-fourth pound, 75 cents; pound, $\$ 2.50$.

\section{HERBS}

Utilize the corners for a few Pot and Sweet Herbs (for flavoring meats, soups, etc.) indispensable to every garden, while Medicinal Herbs will be found useful. Thrive nicely along sunny side of fence in a deep, fairly rich soil.

ANISE-Used for cordials, garnishing and flavoring. Price: Pkt., 5 cents; ounce, 20 cents.

BALM-Leaves used for making pleasant beverages. Price: Pkt., 5 cents; ounce, 25 cents.

BASIL, SWEET-The leaves are used in flavoring soups, etc. Price: Pkt., 5 cents; ounce, 20 cents.

BORAGE-Leaves used for flavoring, and flowers furnish bee pasturage. Most easily grown in any waste place. Price: Pkt., 5 cents; ounce, 15 cents.

CARAWAY-Grown for seeds; used for flavoring. Price: Pkt., 5 cents; ounce, 10 cents.

CATNIP OR CATMINT-Leaves and young shoots used for seasoning. Price: Pkt., 10 cents; ounce, 10 cents.

CORIANDER - Seeds used in the manufacture of liquors, in confectionery and culinary preparations. Price: Pkt., 5 cents; ounce, 10 cents.

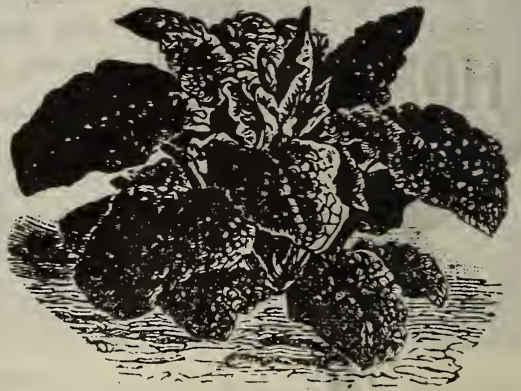

DILL_Seeds have an aromatic odor and pungent taste. Price: Pkt., 5 cents; ounce, 10 cents.

FENNEL, SWEET-Ornamental; when boiled, used in fish sauce. Price: Pkt., 5 cents; ounce, 10 cents.

HOREHOUND-Used for seasoning and cough remedy. Price: Pkt., 5, cents; ounce, 30 cents.

LAVENDER-An aromatic and useful medical herb. Price: Pkt., 5 cents; ounce, 20 cents.

MARJORAM, SWEET-Leaves and shoots for seasoning. Price: Pkt., 5 cents; ounce, 20 cents.

PENNYROYAL-Agreeable odor and flavor. Price: Plsto, 10 cents; ounce, 75 cents.

ROSEMARY - The leaves of this plant are aromatic. Price: Pkt., 5 cents; ounce, 20 cents.

SAGE-An indispensable herb for seasoning. Price: Pkt., 5 cents; ounce, : 20 cents.

SUMMER SAVORY-Used for flavoring soups. Price: Pkt., 5 cents; ounce, 15 cents. 


\section{EGG PLANT}

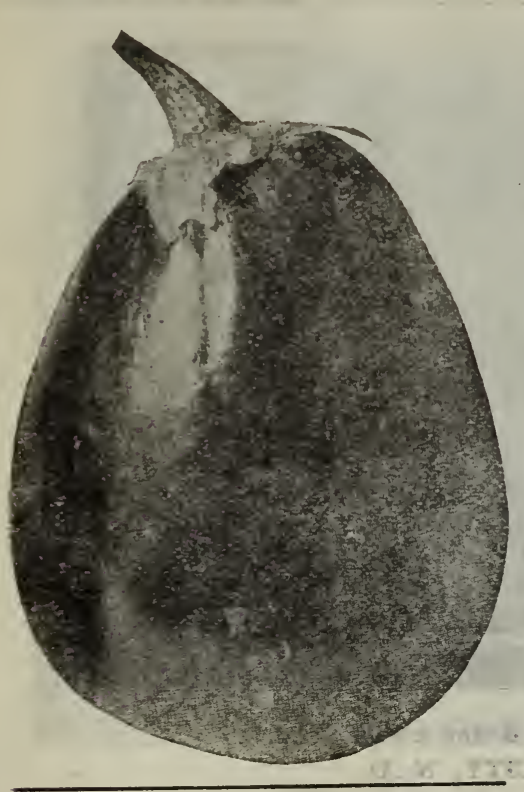

Northern Seed Co., Valley City, N. D.

Dear Sirs:-I wish to say the seeds I bought from you were very satisfactory. believe in buying "Home Grown" seeds. Respectfully,
J. A. JONES, Englevale, N. D.

Northern Seed Co., Valley City, N. D. Dear Sirs:- The seeds I bought from you are good and all grew well. Our Beets and Carrots are very good and we Beets and Carrots are very good and we
are well pleased. You may get an order from us next year.

YRS. G. GRÖGAN, Marie, N. D.
The handsomest type and most perfect strain of Egg Plant in existence. The plants are stocky and low branching, stalks entirely free from spines, and produce continually handsome, deep purple fruits of largest size and most perfect symmetry. The plants usually bear eight to ten immense fruits of the finest quality before being killed by frosts. Price: Large pkt., 10 cents; ounce, 40 cents; one-fourth pound, $\$ 1.40$; pound, $\$ 4.75$, postpaid.

Endive-This plant furnishes an attractive and appetizing salad for the fall and winter months, or by repeated sowings a supply may be had nearly all the year around. Useful in flavoring soups, stews, etc.

Green Curled-Leaves finely cut. Price: Pkt., 5 cents; ounce, 15 cents; one-fourth pound, 50 cents; pound, $\$ 1.40$. Postpaid.

White Curled-Very beautiful, leaves need no blanching: Price: Pkt., 5 cents; ounce, 15 cents; one-fourth pound, 15 cents; pound $\$ 1.50$.

Okra or Gumbo, Mammoth Long Podded-Exceedingly productive and bears splendid dark green pods from eight to nine inches long. It does not grow hard. Price: Pkt., 5 cents; ounce, 10 cents; one-fourth pound, 25 cents; pound, 75 cents, postpaid.

Gourds-Japanese Nest Egg Gourd-Resemble exactly in color form and size the eggs of hens; do not crack and are uninjured by cold or wet. The vine is useful for covering screens, etc., being quite ornamental. Price: Pkt., 5 cents; ounce. 15 cents; onefourth pound, 40 cents.

Mixed Gourds-These are desirable for many places where an immense amount of vine is wanted quickly. The fruit is unique and ornamental, and often useful. The small, fancy Gourds are excel. lent toys for children, while the larger Gourds may be used as dippers, sugar troughs. or bowls. All kinds including Nest Egg, Dish Cloth, Dipper, Japanese, etc. Price: Plkt., 10 cents; ounce 15 cents; one-fourth pound, 50 cents, postpaid.

Mustard-Southern Giant Curled-Used largely for salad; especially in the South. Price: Pkt., 5 cents; ounce, 10 cents; two 'ounces; 15 cents; one-fourth pound, 20 cents; pound, 65 cents; postpaid.
Northern Seed Company, Valley City, N. D.

Gentlemen:-The garden seeds I ordered from you came promptly, they, all grew and the results are good. The seed is $\mathrm{O}$. $\mathrm{K}$.

Yours truly,

A. I. PARKY, Berthold, N. D.

Northern Seed Company, Valley City, N. D.

Dear Sirs:-I wish to inform you your seeds have done well with us, especially the Brumus Inermus and Early whil with us, especially Ohio Potatoes. The rest of my garden the long dry spell.

well as could be expected Yours truly, FRAN F. PROVAN, Marion, N. D.

Northern Seed Company, Valley City, N. D.

Northern Seed Company, Valley City, N. D. bought from you last spring were in every respect the very best. I can cheerfully recommend them to any one want ing the best in the line of seed. Yours truly,

OSCAR ELLUND, Warren, Minn.

Northern Seed Company, Valley City, N. D.

Sirs:- The seeds I received from you were all right, especially the potatoes which were in the ground only six weeks and were big enough to use. I am well satisfied with all and expect to order more next spring.

Yours truly,

Northern Seed Company, Valley City, N. D.

Gentlemen.-The seed corn I got from you last spring all is all right and is going will get my order,

Hays, S. D., Box 46.

Northern Seed Company, Valley City, N. D.

Gentlemen:- Having received Seed Corn from you last rear I wish to say that I am very well pleased with the seed. It will yield better than forty bushels to the, acre and is good solid corn. Thanking you for past favors, I remain, Very truly yours

IUURRAY PACK, Bryant, S. D.
Northern Seed Company, Valley City, N. D.

Gentlemen:-The Seed Corn I bought from you proved to be of good quality and germination, was of a high per cent. Respectfully yours

ELMER T. JÚDD, Cando, N. D.

Northern Seed Company, Valley City, N. D.

Gentlemen:-The seeds I got from you last spring were very good. Everything came up nicely and is doing fine.$$
\text { Yours very truly, }
$$

Northern Seed Company, Valley City, N. D.

Gentlemen:-The Garden Seeds and Seed Corn purchar ed from you last spring have given the best of satisfaction. I have recommended them to others.

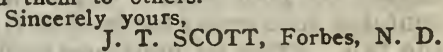

Northern Seed Company, Valley City, N. D.

Gentlemen:-The Seed Corn I got from you last apring was fine. I believe that every kernel grew. I have a fine stand. Yours respectfully,

WENCIL' HOUDEK, Heudek, S. D.

Northern Seed Company, Valley City, N. D.

Dear Sirs:- I am well satisfied with the Seed Corn re. ceived from you. It has grown fine and will yield a good crop this year. I think it matures very early and is just

what is wanted in this northern country.

ED. F. WERTHMANN, Ipswich, S..D., Route 1.

Northern Seed Company, Valley City, N. D.

Gentlemen:-The seed I bought from you last opring all grew and did well. The Corn is ripe and a good crop. I am sorry that I did not get more of the seed. The Peas were the best that I ever planted, both in quality and quan. tity.

J. I. CLARK, Steele, N. D. 
TheL awn Seed bought from the Northern Seed Company for the State Normal School grounds was highly satisfactory. The Campus now looks fine, and attracts the attention of everybody. It is all right

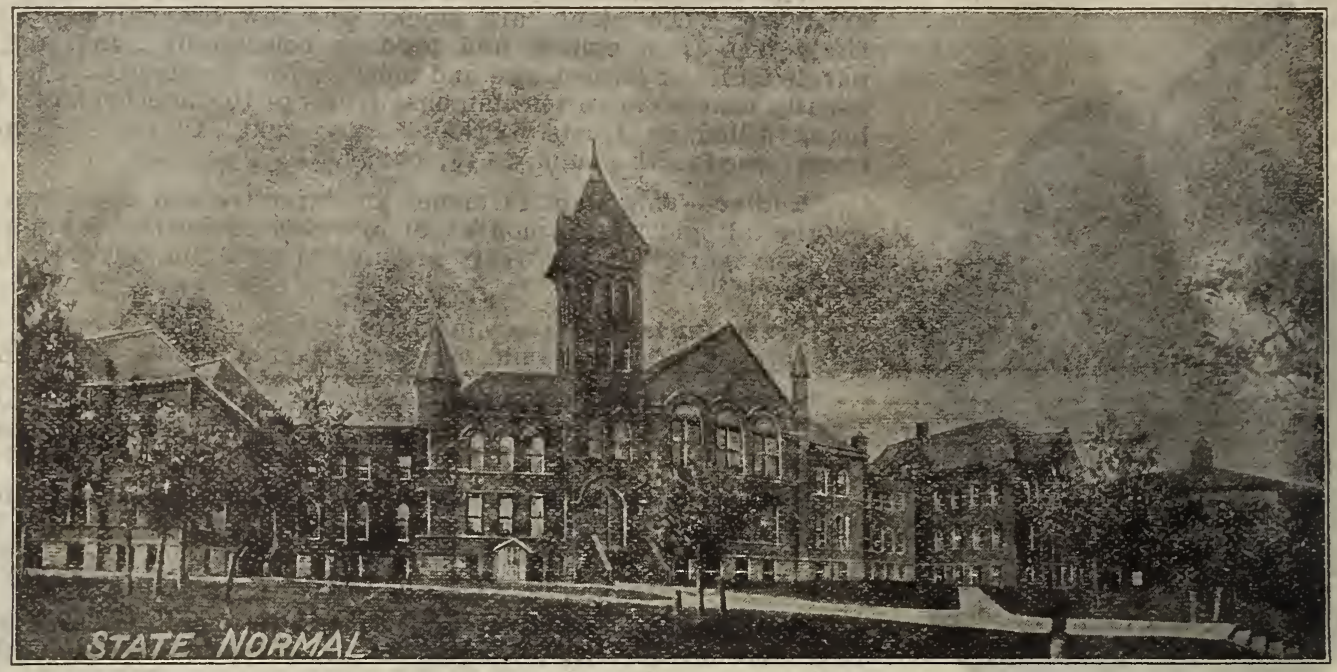

Lawn Was Made From Our "Home Grown Brand Lawn Seed." STATE NORMAL SCHOOL, VALLEY CTTY, N..D.

\section{How to Build a Lawn}

The first essential for a good lawn is four to five inches of black loam, better if supplemented with good clay sub-soil. A lawn should be prepared perfectly smooth, all the lumps being broken up with a rake before the seed is sown. Lawn seed should be sown very shallow, better to put the seed on before a hard shower and let the rain wash it in. A great mistake is made in sowing lawn grass seed too deep.

If an immediate lawn is desired do not make a mistake of sowing a nurse-crop with the seed. Sow the lawn grass seed without a nurse crop and if any weeds should appear before the grass crop is up they should be pulled out by hand.

Water should be used very freely on all lawns. If city water is handy the lawn should be wet down twice a week.

Lawns in this northern country should be coated over with a thick coat of well rotted manure every fall. This not only enriches the soil for the next year but pre serves the grass in fine shape:

\section{"Home Grown Brand of Lawn Grass Seed"}

Great care should be exercised in the selection of grass seed for lawn purposes and we have found that our mixture far surpasses anything yet sold in this territory for hardiness, quickness to take root, and evenness. This seed is especially mixed for lawn purposes for the northern territory and surpasses anything so far put upon the market by eastern or southern houses.

As much care should be exercised in sowing lawn seed that is suited to your climatic conditions as you would take in selecting any other seeds. The impediment in making lawns is more than half caused by poor seed. If you wish your home attractive, use "Home Grown" Lawn Seed. This mixture contains such grass seeds.as will create green turf earliest in the spring and hold its natural color latest in the fall. Price by mail postpaid, pound 45 cents. By express or freight at the purchaser's expense, pound 35 cents; 50 pounds at 30 cents; 100 pounds at $2 \&$ cents; on $\Theta$ quart pkt., 35 cents.

. Northern Seed Co., Valley City, N. D.

Gentlemen: Our flower seeds are the best we have ever used and are second to none for quality. We heartily recommend your house to anyone wanting seeds.

Yours respect fully,

ALBERT CANNON, Custer Co., Mont.

Northern Seed Co., Valley City, N. D.

Gentlemen; I would recommend your seeds as the very best for Northwestern climate. My garden was grown on new breaking, but it was a dandy.

Yours very truly,

MRS. P. D. ORR, Williams Co., N. D.
Northern Seed Co., Valley City N. D.

Gentlemen: Our garden is a standing advertisement for you. Every seed seems to have grown. It has attracted the attention of people for miles around. Yours truly,

MRS. J. C. BANKS, Crook County, Wyoming. Northern Seed Co., Valley City N. D.

Gentlemen: Last spring I purchased some vegetable seeds and also some flower seeds from you. I am happy to say they did splendidly, especially the Sweet Peas, which are perfectly beautiful. Yours truly,

MAUDE SEMOND, Spink Co., S. D 


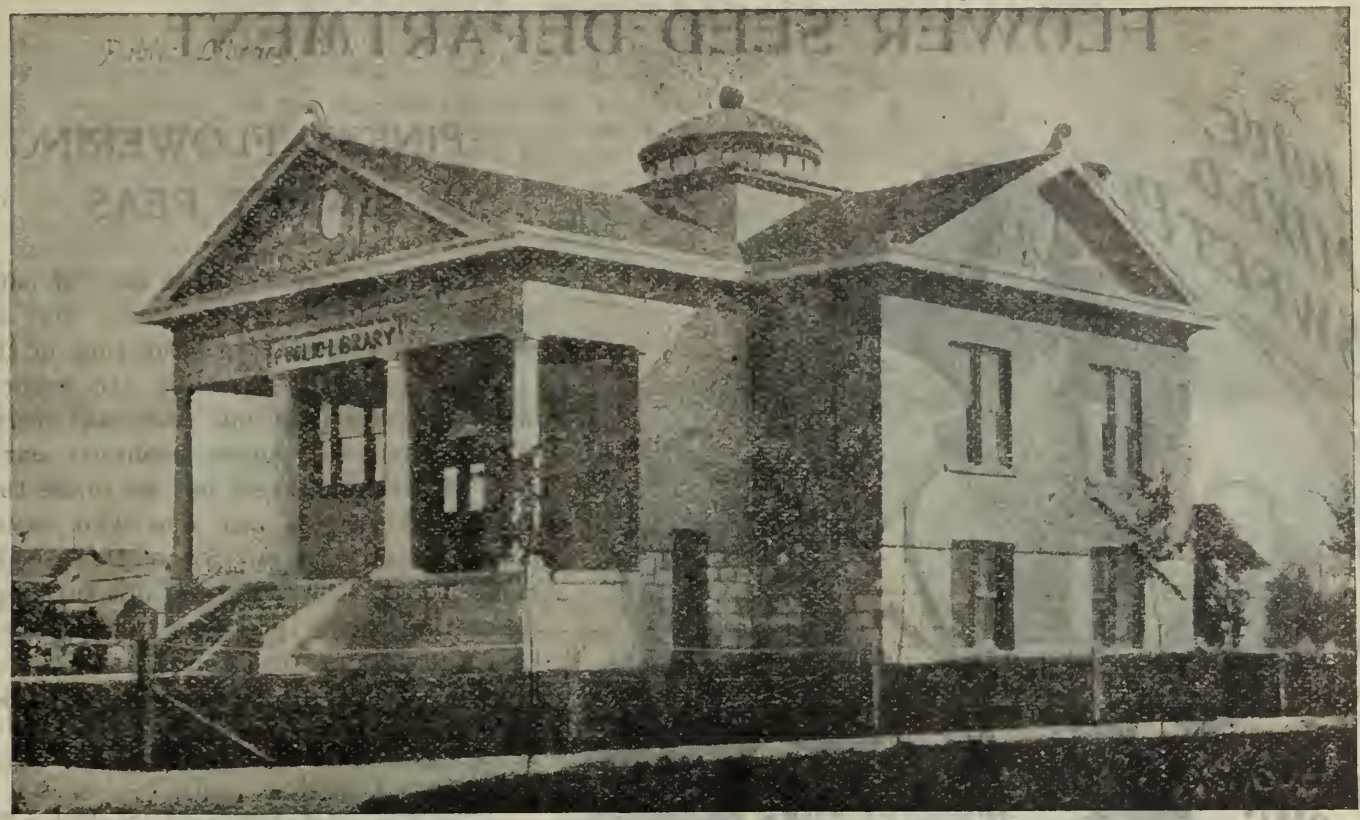

Lawn Was Made From Our "Home Grown" Brand Lawn Seed

This cut and the one on the opposite page illustrates what can be done with our "Home Grown" Brand of Lawn Grass seed, when proper care is taken of the land. There is "o one thing that will pay the home owner so much in dollars and cents and also in satisfaction as the lawn.

The old methol of going at the lawn haphazard, sprinkling on a little grass seed of any kind whatever, or going to the store and buying a little seed that purports to be lawn seed, has been found to be a failure. The only reliable way, is to buy seed from a house that is able to sustain, and pay money enough for it, so that you are satisfied you are getting the best grade of seed and then put on an abundance of seed. Too many people follow a false economy in not putting enough seed on the lawn. A bag of lawn seed should be kept on hard after the lawn is started and a sprinkling on the places that refuse to grow, with lawn seed before a thunder shower if possible, also in places that do not seem to thrive well in the lawn. Apply our lawn fertilizer which is prepared with the ingredients for Northern soil in view.

\section{FERTILIZER AND LAWN DRESSING}

Fertilizer and Lawn Dressing is the result of careful study, experiments and experience. It contains in just the right proportions, a concentration of the elements which nourish and feed grass into luxuriant growth. It produces a rich, green color and insures a permanent evenness over the whole surface of your lawn. It is not unpleasant to handle and as it is dry and fine, it is easily put on. Two or three applications in a season, at the rate of a-pound to every one hundred square feet, will keep your grass in flourishing condition-perfectly healthy and able to stand any ambunt of sun if well watered. We make but one kind of lawn dressing. Price by express or freight, bag of 10 pounds, 55 cents; 25 pounds, $\$ 1.00$; 50 pounds, $\$ 1.75 ; 100$ pounds, $\$ 3.00 ; 500$ pounds, $\$ 2.75$ per 100 pounds.

When and How to Put it on Lawns-The first application should be in the early spring-just as soon as the frost is out of the ground. Scatter it by hand carefully and evenly, so the distribution will be uniform. Use from ten to fifteen pounds on every thousand square feet and if it can be put on just before a rain, so much the better. If unable to do this, wet it down with a hose as soon as possible after applying. If the weather is very hot and dry, put dressing on early in the morning or late in the evening, and wet it down at once. If your lawn is new, double the quantity of dressing for each thousand square feet, sow it broadcast and rake it before seeding. Thin or light cilored spots in a lawn should have extra treatment, which will speedily restore them to vigor and color.

For House Plants-A teaspoonful of our Feed, or increased, by judicious use our Fertilizer. Sprinkle it carefully in the beds and both foliage and blossoms will be large and vivid in color. $\Delta$ teaspoonful or so stirred in the soil about the roots of each plant two or three times during the season will give you astonishing results. Always water plants thoroughly after fertilizing.

For House Plants - A teaspoonful of our Fertilizer dissolved in a quart of water and this solution poured around the roots of house plants will greatly invigorate them. Stir solution while pouring so as to keep it well mixed, and apply as often as the plants seem to need it-say every week or ten days or un. til they are as healthy as you wish. 


\section{FLOWER SEED DEPARTMENT}

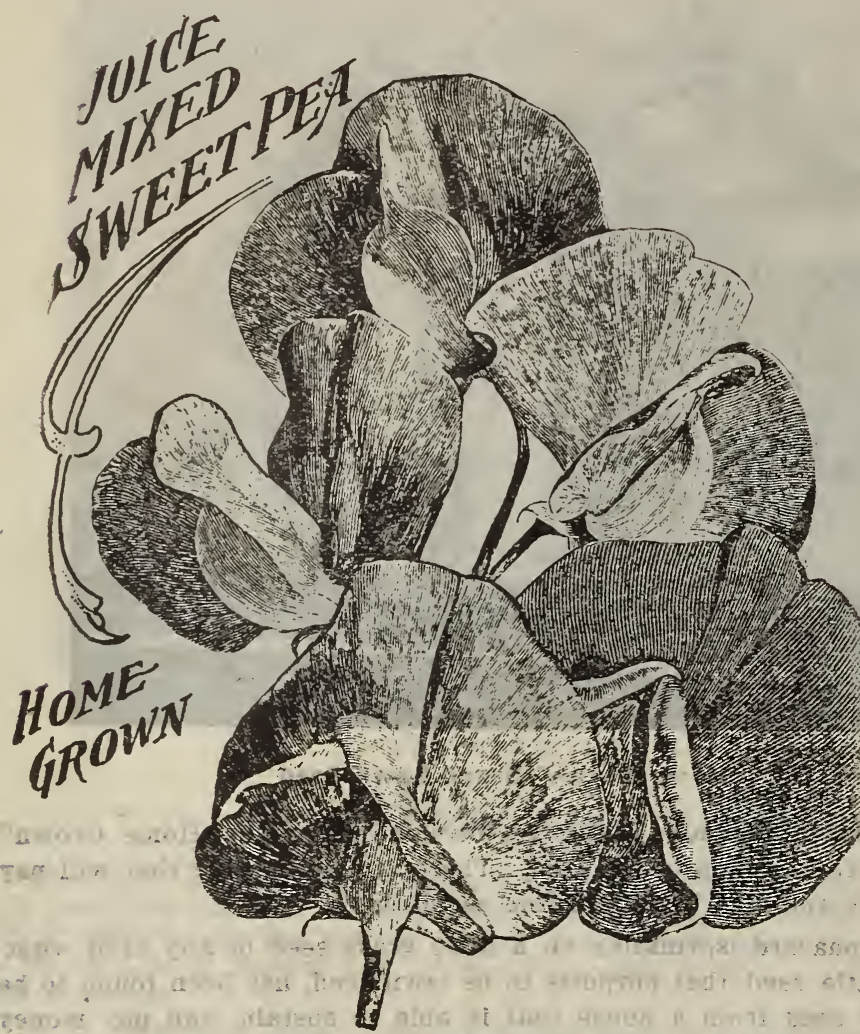

\section{FINEST FLOWERING SWEET PEAS}

We have taken a great deal of pains in giving color to our $\$$ weet Peas. Our Mixed Sweet peas contain the effulgence of the incif dual flowers. We have had arbors the last two years from our seed that were cer. tainly wonders. Space prohibits our running pictures of these, but we make the following offer: To any one who buys one pound or more of our Sweet Pea Seed that from a color standpoint, do not surpass anything they have previously had, we will cheerfully refund their money. Price: Pkt., 5 cents; ounce, 10 cents; one-fourth pound, 25 cents; one pound, $\$ 1.00$.

Northern Seed Company, Valley City, N. D.

Gentlemen:- The Winter Radish Seed I ot from from was splendid. The radish were 6 inches long and part of June. $\quad$ A. RISING, Burkey, N. D.

Northern Seed Company, Valley City, N. D.

Gentlemen:- We think the "Northern Seed Com. pany's seeds the best we have ever used. Wishing much luck to the Northern Seed Company, I am, Yours truly ERNST H. SCHMIDT, Hope, N. D.

\section{DIFFERENT PANSIES IN ONE BED FROM OUR} SEED

We buy our Pansy Seed from one of the largest and most particular pansy producers in the world. One of the pansy beds last year produced 158 different shades and varieties. Often times single flowers, under good conditions, will measure 2 inches in diameter. It is with a great deal of confidence we recommend our pansy seed to the particular flower grower. We know it will give satisfaction. Price: Pkt., 5 cents each.

Nortliern Seed Company, Valley. City, N. D.

Gentlemen:-I sent you an order last spring but you returned the money stating that the oats were not as good sayou thouglit ther were when you cataloged them. Any firm sending a check back is an honorable firm. Respectfully,

FRED OBEN. Lakota, N. D.

Northern Seed Company, Valley City, N. D.

Gentlemen:-I was somewhat disappointed by the looks of the Corn I bought from you last spring as it was not vrey "showy" looking, but after testing it I found it to be good seed and in the field it showed even better for it did not miss a hill.

Yours for business

FRED HAMMERMEISTER, Wahpeton, N. D.

Northern Seed Company, Valley City, N. D.

Gentlemen:-We were very well pleased with yaur seeds. We find them the best we have used in the state; they gave splendid results, dry as the season has been. The beets and peas were the best ever. Yours respectfully,

CHAS. E. BEERY, Bentley, N. D

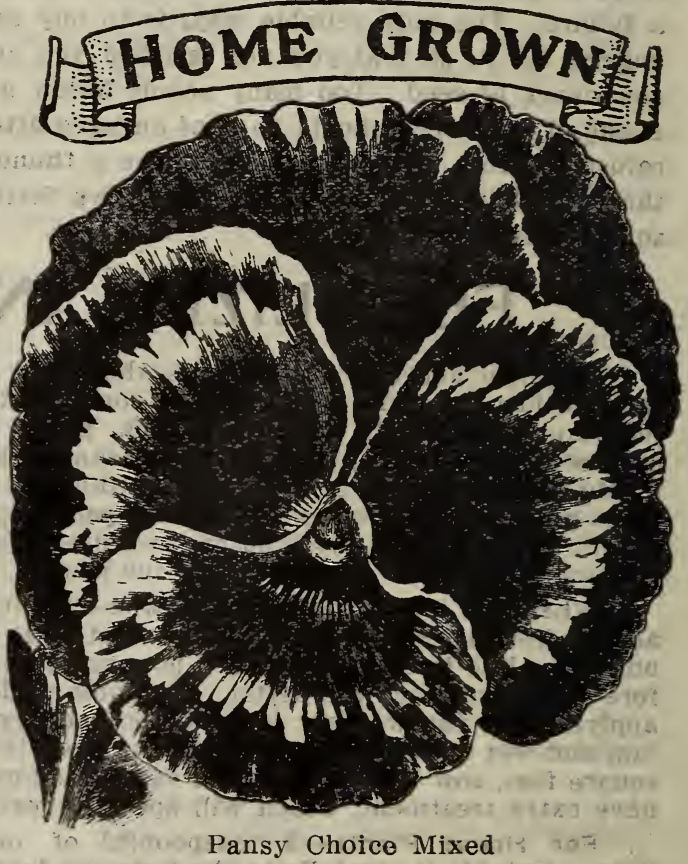

Northern Seed Company., Valley City, N. D.

Gentlemen:-I am glad to let you know that the New Improved Squaw Corn you sent me turned out very fine, the best corn in the neighborhood.

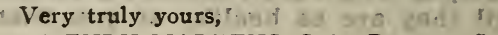
HENRY MARTENS, Lake Preston, S. D. 


\section{Men That Have Built the}

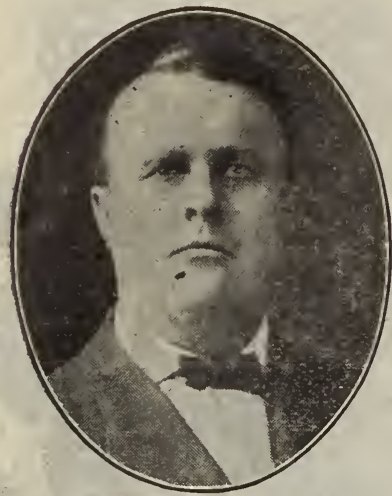

A. B. coX, Valley City

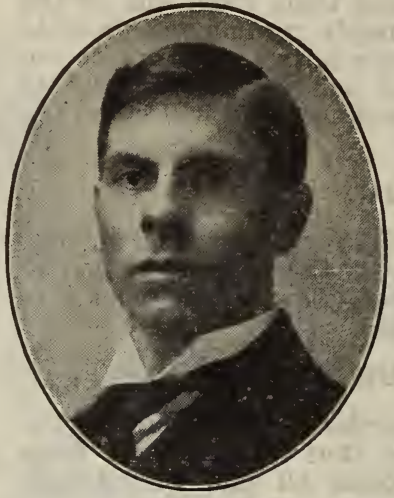

A. S. SIGURDSON, Valley City

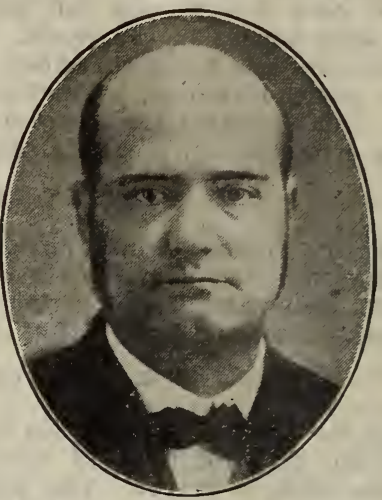

DR. E. A. PRAY, Valley City

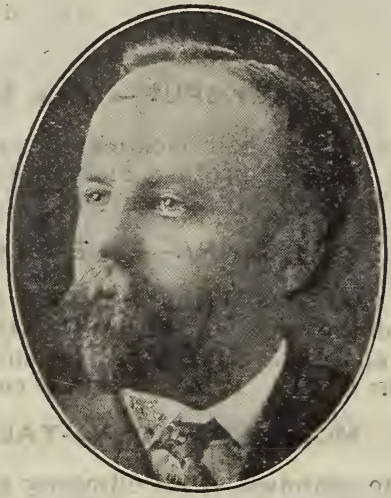

AMASA P. PEAKE, Valley City President

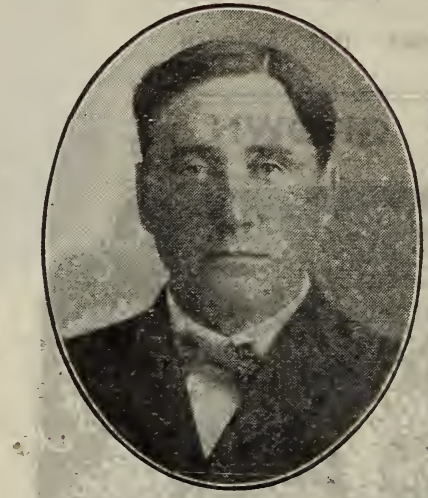

E. S. DeLANCEY, Valley City V. P. and General Manager

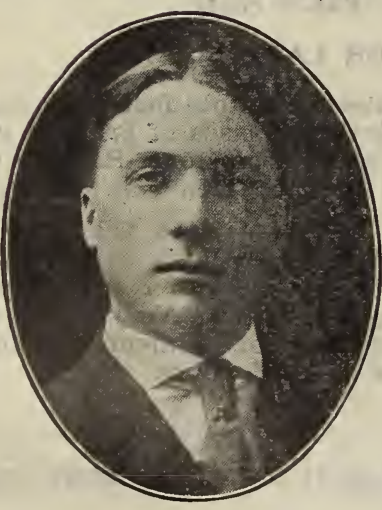

FRANK HEIMS, Valley City

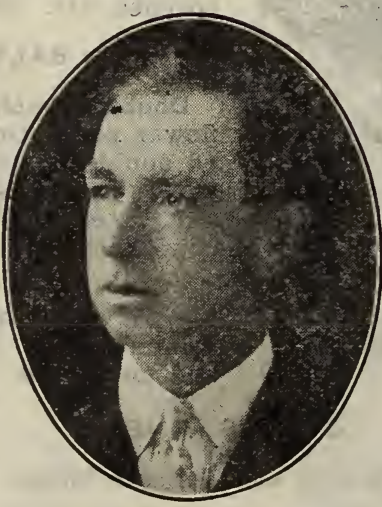

W. HARRY CODDING, Valley:City

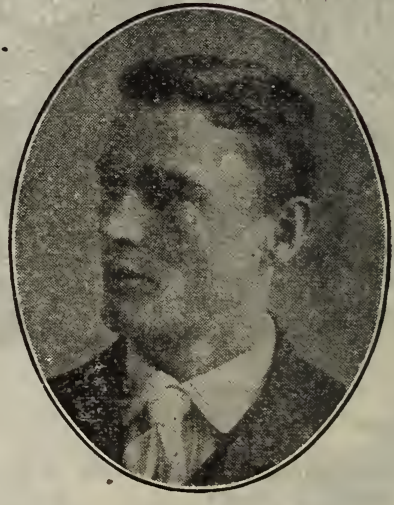

MARK A. SMITH, Valley City

Sixteen Men Who Have Been Prominent in Business, Dolitical and Social Life of the State for One-fourth of a Century

Is it not safer to trust these men with your seed business than some stranger in an eastern city? 


\section{Northern Seed Company}

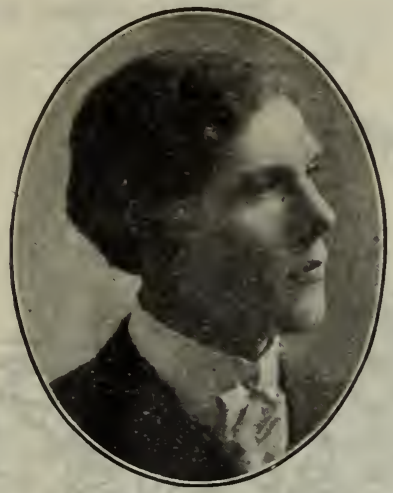

T. S. HENRY, Valley City

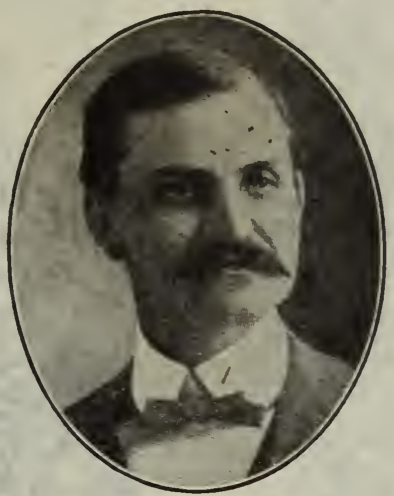

T. E. DYBDAL, Elbow Lake, Minn.

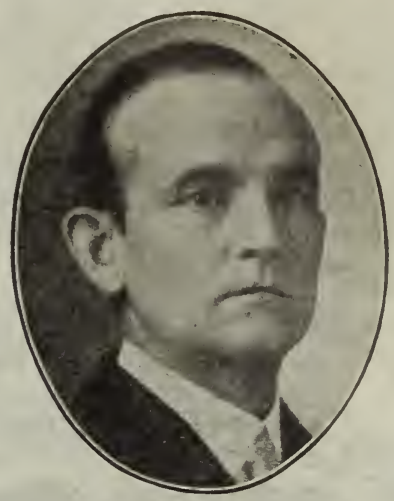

J. A. REGAN, Fessenden, N D.

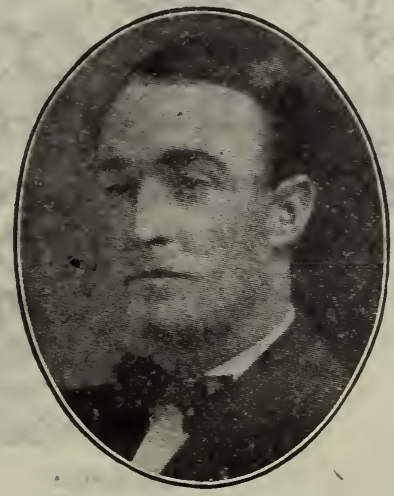

JOHN W. MURPHY Valley City Secretary

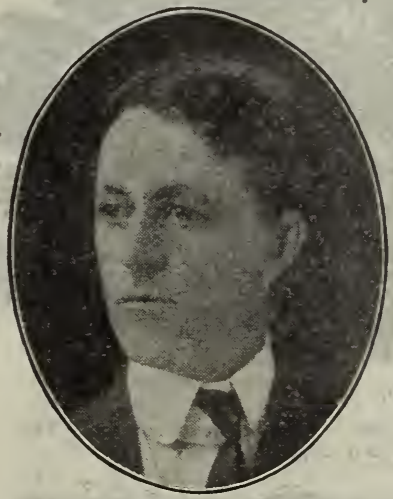

CHAS. W. NELSON, Valley City Treasurer

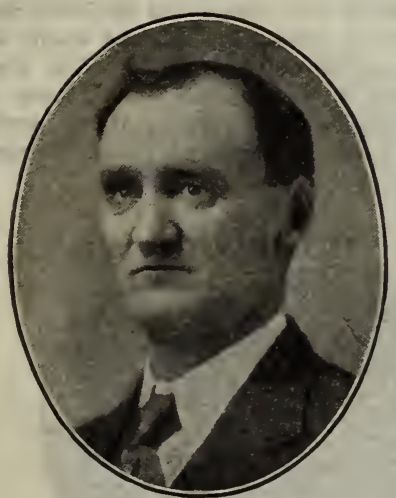

JOHN LAIRD, Valley City

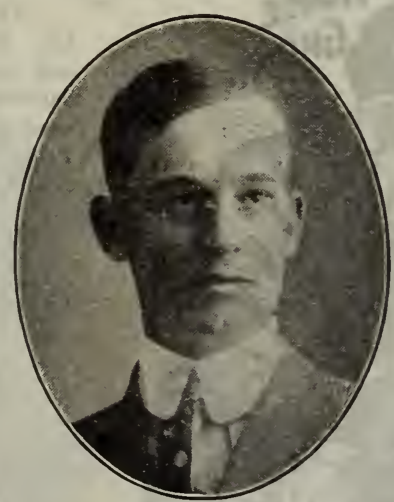

GEORGE D. KELSEY, Valley City

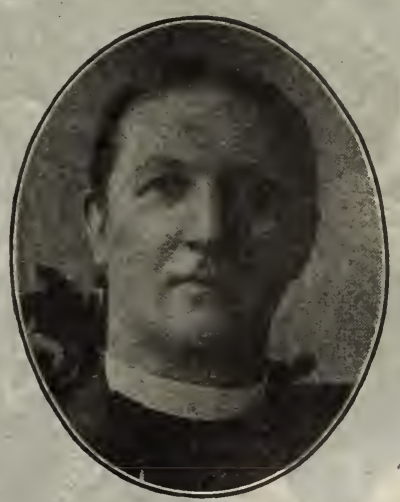

REV. L. G. MOUL TRIE, Valiey City

Sixteen men who are old settlers in the State, and who know the conditions of the State. Are not these men better adapted to attend to your Seed wants than men who live in some eastern city, who have never been in the State, and' care nothing about you, except the money they make out of you? 
A hardy annual highly esteemed for its delicate fragrance. It grows well only during cool, moist weather of early spring and late fall months. Price: Pkt., 5 cents.

Northern Seed Co., Valley City, N. D.

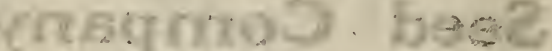

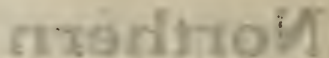

Gentlemen:-I found your seed all O. K. and up to the standard in every respect.

\section{POPPY-MIXED CARNATION}

Hardy annual. For absolute richness and variety of color the flowers are unequalled. Simply scatter the seed in the open ground and a mass of beauty will result, which will amply repay the grower. Price: Pkt., 5 cents; ounce, 50 cent

HOLLYHOCK (Althaes)

For a back ground to a flower garden there can be nothing better. Sow in June or July and plants will bloom the next summer. Hardy perennial. Price: Pkt., 5 cents.

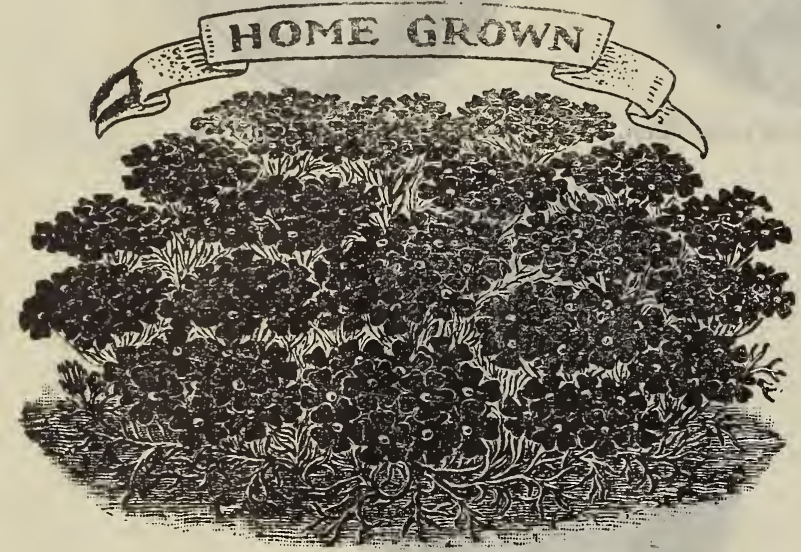

VERBENA-FINE MIXED.

Fine for mounds, vases, etc. Half-hardy perennial. Finest mixtures. Price: Pkt., 5 cents.

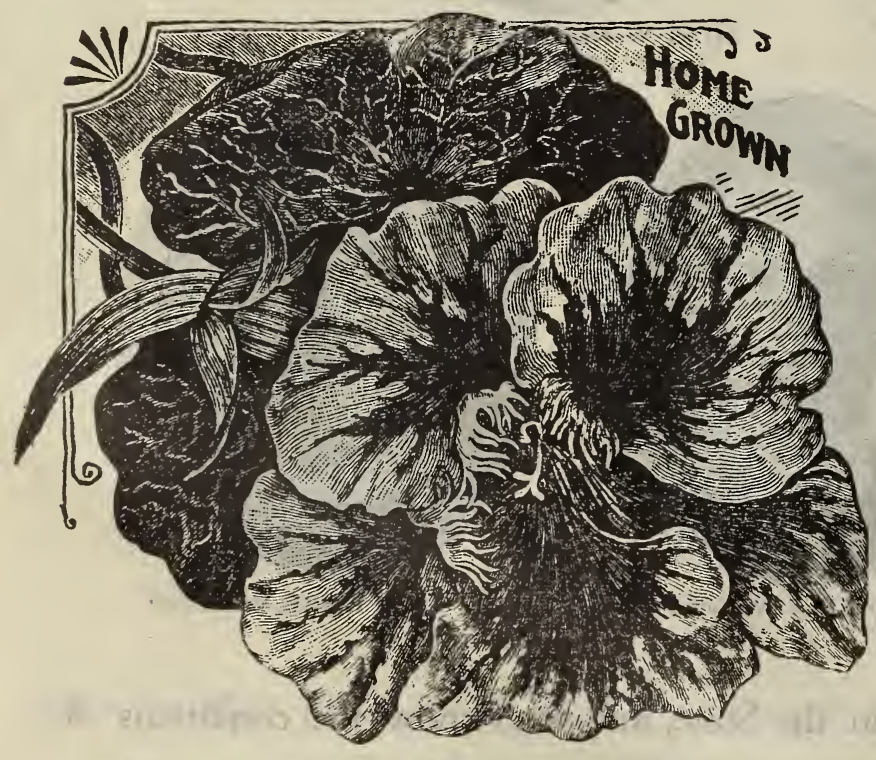

Northern Seed Co., Valley City, N. D.

Gentlemen:-The seeds which I got from you last spring were fresh and a large per cent germinated, showing care in the selecting and caring for them. I expect to order from you again, next spring, as I was well pleased with your seeds this year. Yours truly,

A. G. McKEAN, Topbar, S. D.

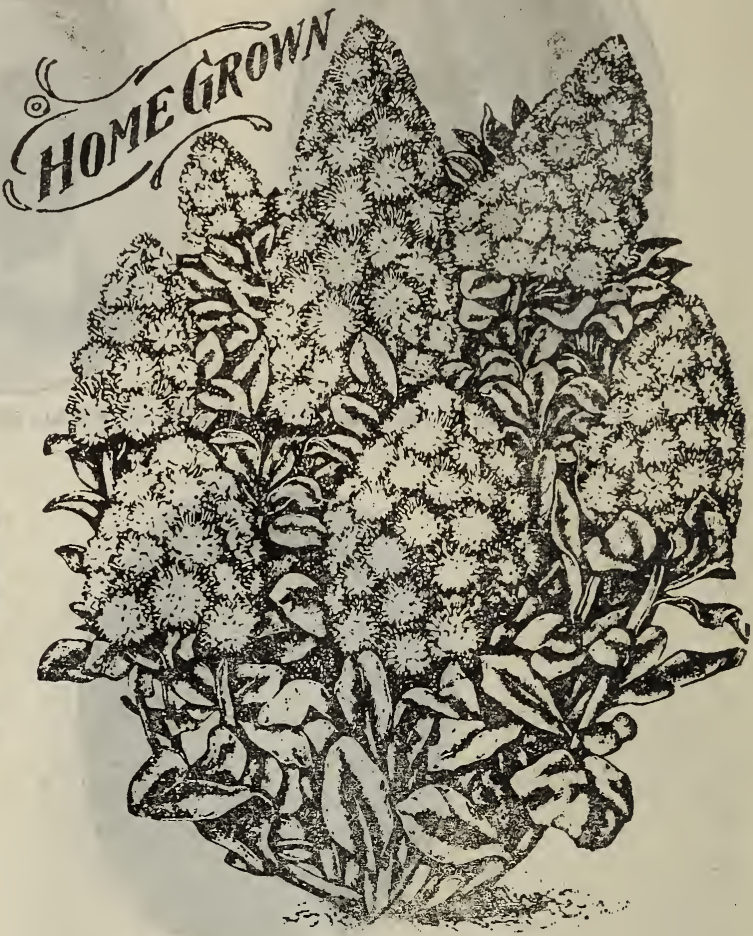

Mignonette

NASTURIUM DWARF-MIXED.

This plant is and always will be justly popular. It grows in almost any soil and stanøs beat and drought as few other plants can. The Dwarf varieties make very fine beds. The seeds are used as a substitute for capers. Hardy annual. Price: Pkt., 5 cents; one-fourth pound, 40 cents; pound, $\$ 1.25$.

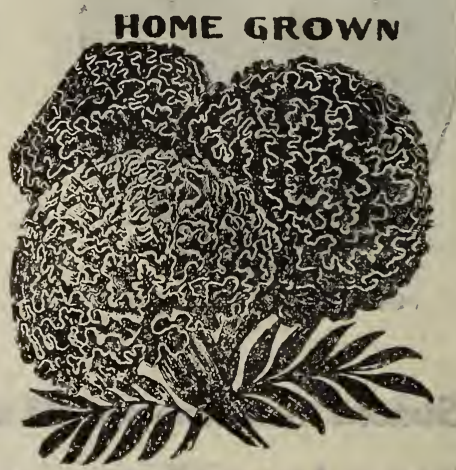

MARIGOED-DWWARF FRENCH.

Colors: Red, yellow, brown and varigated. Can-be grown to good advantage in little clumps with other plants, in the front of shrubberies or in the garden border. Price: Pkt., 5 cents. 

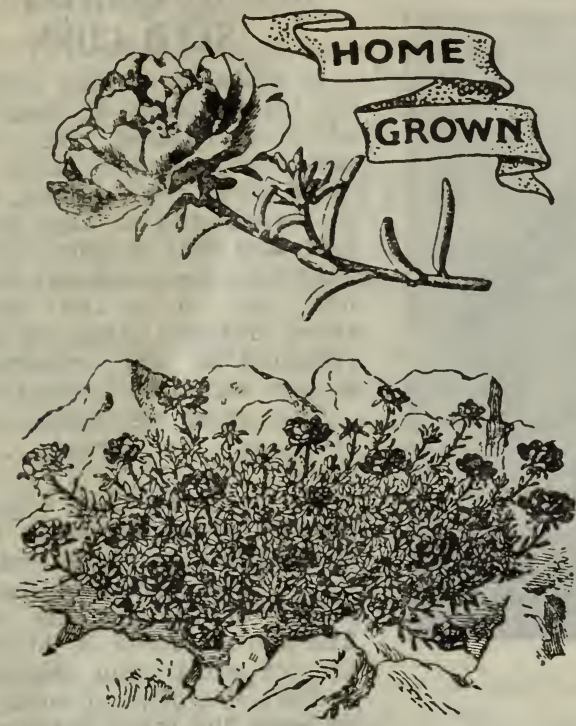

PORTULACCA-SINGLE MIXED

A small trailing plant, bearing bright delicate flowers. It thrives in a sandy soil, with plenty of light and heat. Hardy annual. Price: Pkt. 5 cents.

\section{PETUNIA-FINE MIXED SINGLES}

Very showy in beds or masses. Universal favorites on account of their richness of color and fragrance, continuous blooming, succeeds well everywhere. Price: Pkt., 5 cents.

\section{PINK-DIANTHUS}

Blooms are rich, pleasing colors and nothing. can surpass the exquisite fragrance of some varieties. They are hardy and become perennial in warm climates. Pkt., 5 cents.

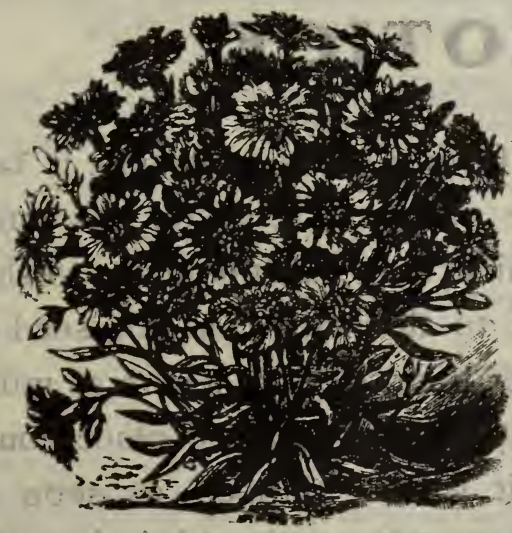

Northern Seed Co., Valley City, N. D.

Gentlemen: After looking around last spring, I bought of your manager some of your "Home Grown". clover seed. I can say I have never been better pleased with a lot of seed. It came to hand promptly and I found it of the very best quality. I am through with cheap Eastern seed. Yours, HENRY SAMPSON, Pres. Bank of Elbow Lake, Grant Co. Minn.

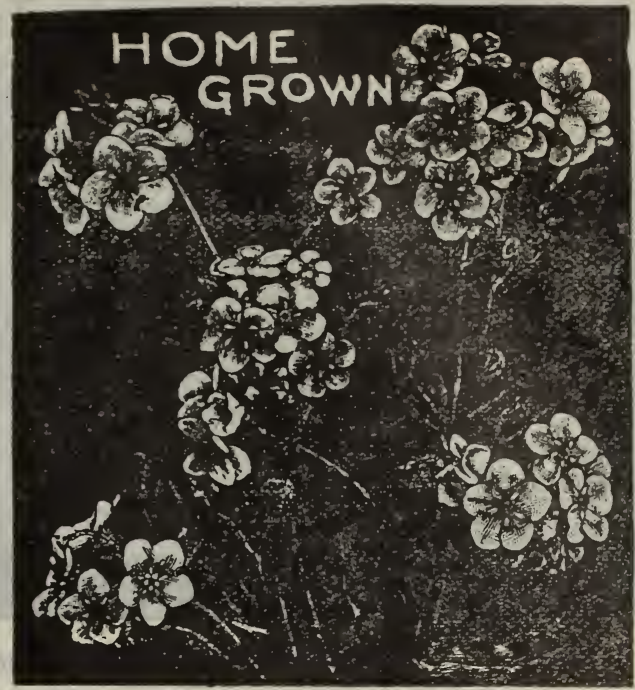

\section{FORGET-ME-NOTS-BIUE}

An old favorite bearing cluster of star shaped flowers; thrives well in shade or open border. Hardy perennial. Price: Pkt., 5 cents.

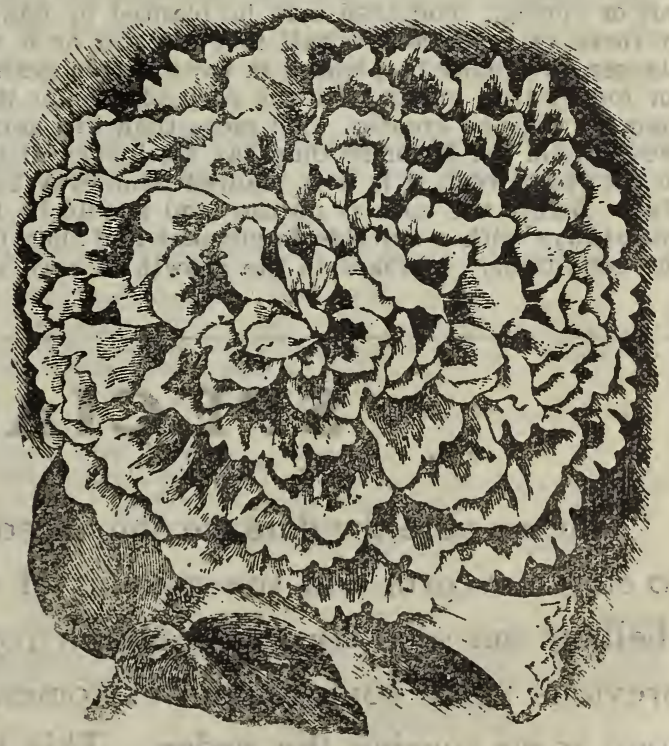

Northern Seed Co., Valley Cit $y$, N. D.

Gentlemen: I bought from you last season my garden seeds and also by Early Ohio Potatoes. I found the garden seeds all good and early. The potatoes were a very fine lot and I can say this is the first year I have ever had potatoes that were all of one kind, and right in every way.

Yours respectfully,

GUSTINA T. SMITH, Beltrami Co., Minn.

Northern Seed Company, Valley City, N. D.

Gentlemen:-The Timothy Seed and Bromus Seed I bought from you last spring were very fine and clean. I sowed same with wheat and they have made a good stand. Yours respectfully, AIRFRT DUBAY, Fonda, N .D. 


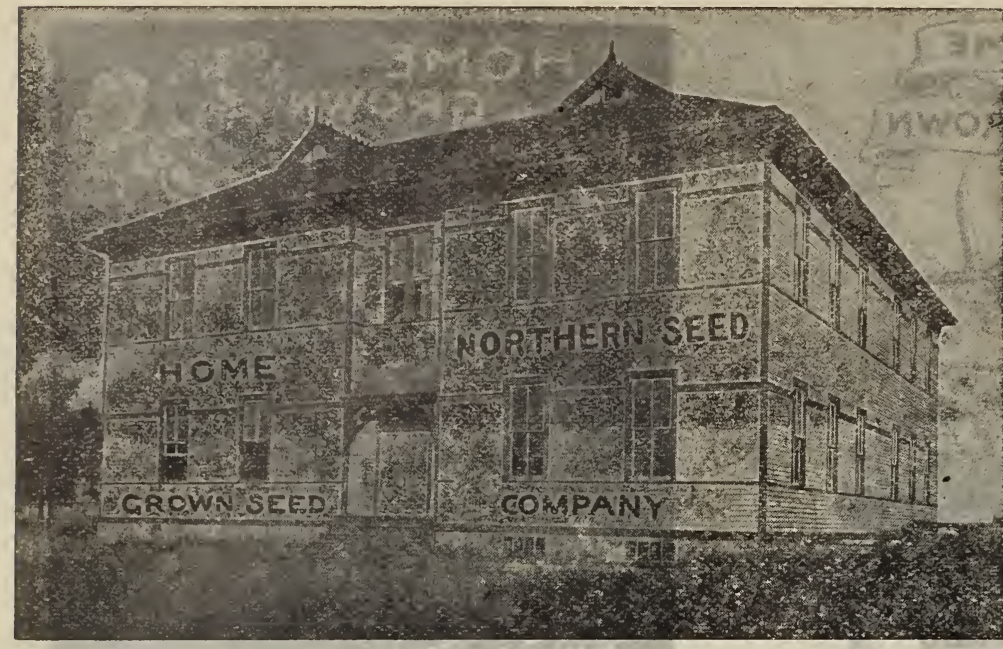

Elbow Lake Corn Warehouse

OUR GUARANTEE ON SEED CORN

In addition to our guarantee on inside page of front cover of this catalog, we guaran. tee that all our seed corn, upon leaving our hands, is true to variety and to high germination, and that if upon receipt of shipment the purchaser does not find this to be the case, we agree that said shipment shall be returned at our expense and money refunded promptly.

The price we make on seed corn is for strictly "Home Grown" seed.

We will furnish seed corn grown 100 to 150 miles farther south than we cured our corn for 75 cents per bushel less than prices quoted in this catalog. The prices quoted in this catalog are for extra hand selected and pedigreed stocks of corn, raised at least 200 miles farther north than seed quoted by concerns making anything like similar prices. If you want the cheaper corn we can send it to you. We do not advise it however.

Culture (By Prof. Thomas Shaw): Field corn whether grown for the grain mainly or grown for fodder will grow well on any ground that will gro w good wheat, providing the climate is suitable, but it will grow best on a rich, moist loam with a goodly sprinkling of sand in it and well supplied with vegetable matter. It may come anywhere in the rotations but usually does best on sod when put in tilth or on stubble land. It is best followed by a cereal crop, as wheat or barley. The land may be plowed deeply, fall or spring. The seed may be planted by hand in hills, previously marked off in squares with a marker three to three and a balf feet distant; or it may be planted in these with a hand planter or corn planter, or it may be planted in rows with a grain drill, the rows being three feet apart. When planted for fodder it is put in with the corn planter or the grain drill in rows usually three feet distant, but the distance may be greater. Not more than five kernels should be planted in a hill and in the fodder drills they should not be more than say six inches distant. It is buried to the depth of two to three inches. In the Northwest, it is best planted from May. 1st to June 10th, and preferably during the last half of May. Before the corn is up the land should be harrowed once or twice and as frequently after it is up, but always with a suitable implement and then it should be cultivated every 10 to 14 days, according to the conditions. Increase in the growth of corn will result in the increase in the growth of wheat.

\section{SPECIAL NOTICE}

Please note the date we ship Seed Corn. Owing to the long time it takes us to cure our corn, and the amount of work we put upon it, we do not commence shelling our seed corn until March Ioth, at which time we commence to ship. In previous years some of our customers seemed to think we can ship seed corn as soon as we receive the order. This is an utter impossibility where as much care and attention is put upon the corn as we put upon ours. If you place your order for corn with us, you may rest assured that it will be shipped as soon as it is thoroughly cured, and in plenty of time for you to take a test of it before-planting.

Northern Sejed Co., Valley City, N. D.

Dear Sirs: It gives me much pleasure to tell you" of my success with the seed corn I got from you. It will make 75 bushels to the acre. I planted the first of May. 'The yield is fine in spite of the unfavorable weather we had. I shall use your corn in the future.

GILBERT WALKER, Gorson, Co., S. D.
Northern. Seed Co., Valley City, N. D.

Gentlemen: I have grown your seed curn for the past two years and although last season was not at all favorable I got a good stand. I would not purchase seed corm from any other seed house, for this locality. Yours truly,

F. P. HAWLEY, Billings Co., N. D. 
The difference between "Home Grown" seed corn and seed corn grown two or three hundred miles further south is too familiar with our customers for us to take space $h \in r e$ in describing. It is enough for us to say that we have customers who have the confidence in our corn to assert that they would pay us, If necessary, three times the price that they would pay other seed houses for corn which said seed houses merely claim is produced in the "Northwest."

\section{The Difference is in the Quality}

We wish to call the attention of our customers to the difference between the cost of selecting and preparing our seed and the cost that Eastern and Souther houses are put to in the preparation of seed corn.

In this latitude (North of the Southern line of North Dakota) it is necessary that seed corn be taken from the stock as soon as ripe, placed in suitable racks in a frost proof building, heated by forced ventilation in order that the seed corn shall be properly cured.

Two hundred miles farther south, where the majority of. other seed houses prepare their corn, it must be remembered that seed corn ripens fully six weeks before frost, whereas in this latitude (North of the South line of North Dakota,) we are lucky if we get it thoroughly ripe ten days before frost. Thus the Eastern and Southern houses can take advantage of that six weeks or two months, allowing the corn to hang on the stock in the field, nature furnishing the desired temperature and ventilation.

Just a word in reference as to how we select and prepare our seeds. Our seed corn is grown from extra selected seed, every barren stock of which has been detasseled and the earliest ears selected for seed purposes. Bear in mind the location where our seed corn is produced (North of the Southern boundary line of North Dakota) and compare it with the statement of Eastern and Southern houses, who merely say "our corn is Northern Grown" or "Grown in the Northwest."

We sort our seed corn in the field, take it to our dry house, which is a lathed and plastered affair, double floored and thoroughly frost proof building, the same as any of your best dwellings, heated by furnace and power forcing air through the racks. Compare this method with the methods of Eastern and Southern houses, which simply allow the corn to hang on the stock until it is perfectly dry, shipping it into their warehouse, putting it through a "kiln dry" (which according to the best authorities injuries the corn) shell it, sack it up and store it for spring delivery.

In comparison, the corn that Eastern and Southern houses place upon the market is no more adapted to our conditions (North of the South line of North Dakota) than fodder corn seed would be adapted to the growing of an ear corn crop in Southern Minnesota.

Northern Seed Co., Valley City, N. D.

Gentlemen: The fifty acres of seed corn raised frum your Minnesota No. 13 seed is the finest field if corn ever grown in this county. I shall need some more field seeds grown in this county. I shal
next spring. Yours truly,

NELS JÄCOBSON, Morton Co., N. 1).

Gntlemen: The seed corn bought from you gave the best of satisfaction, it being a dry year here. My neighbors want me to save seed for them from the crop raised from your seed corn.
B. R. HENRY, Ward County, N. D. B. R. HENRY,
Valley City N. D.

Northern Seed Co., Valley City N. D. Dear Sirs: The corn purchased from you came up
(1) will want splendidly, considering the backward season. I will want
more seed for another year.

Northern Seed Co., Valley City N. D.

Dear Sirs: The Northwestern Dent Corn I purchased from you did well. I have a large crop of both corn and fodder.

Yours truly,

J. M. LEIGHTON, Johnson Co., Wyoming.

Northern Seed Co., Valley City, N. D.

Gentlemen: We received the shipment of flin: seed corn you sent us and used it for planting in where our regular crop had drowned out in the river botto:n. It was plasited fully six weeks later- than our ordinary seet corn and ma. tured before the rest of the crop. It is nis wonder your can raise corn in North Dakota if you furnish tlic farmers this
kind of seed. kind of seed.

ALF. J. CUMMINGS, Rice County, Minn.

Northern Seed Company, Valley City, N. D.

Gentlemen:-The Northern Dent Corn I bought from you was very satisfactory and will ripen a crop by Sept. 10th. Yours respectfully, J. E. RUSSELL, Havana, N. D.
Northern Seed Company, Valley City, N. D.

Gentlemen:-The Garden Seeds and Seed Corn purchas. ed from you last spring have given the best of satisfaction. I have recommended them to others. Sincerely yours,
J. T. SCOTT, Forbes, N. D.

Northern Seed Company, Valley City, N. D.

Gentlemen:- The Seed Corn I got from you last spring was fine. I believe that every kernel grew. I have a fine stand. Yours respectfully,

WENCIL, HOUDEK, Heudek, S. D.

Northern Seed Company, Valley City, N. D.

Gentlemen:-The seed I bought from you last spring all grew and did well. The Corn is ripe and a good crop. I am sorry that I did not get more of the seed. The Peas were the best that I ever planted, both in quality and quan. tity.

J. L. CLARK, Steele, N. D.

Northern Seed Company, Valley City, N. D.

Dear Sirs:-I am well satisfied with the Seed Corn received from you. It has grown fine and will yield a good crop this year. I think it matures very early and is just what is wanted in this northern country. Respectfully,

ED. F. WERTHMANN, Ipswich, S. D., Route 1.

Northern Seed Company, Valley City, N. - D.

Gentlemen:-The Seed Corn I bought from you proved to be of good quality and germination, was of a high per cent. $\quad$ Respectfully yours, ELMER T. JUDD, Cando, N. D.

Northern Seed Company, Valley City, N. D.

Gentlemen:-The seeds I got from you last spring were very good. Everything came up nicely and is doing fine. Yours very truly. L. S. ESPESETH, Lansford, N. D. 


\section{The King of Early Dent Corns-Northwestern Dent}

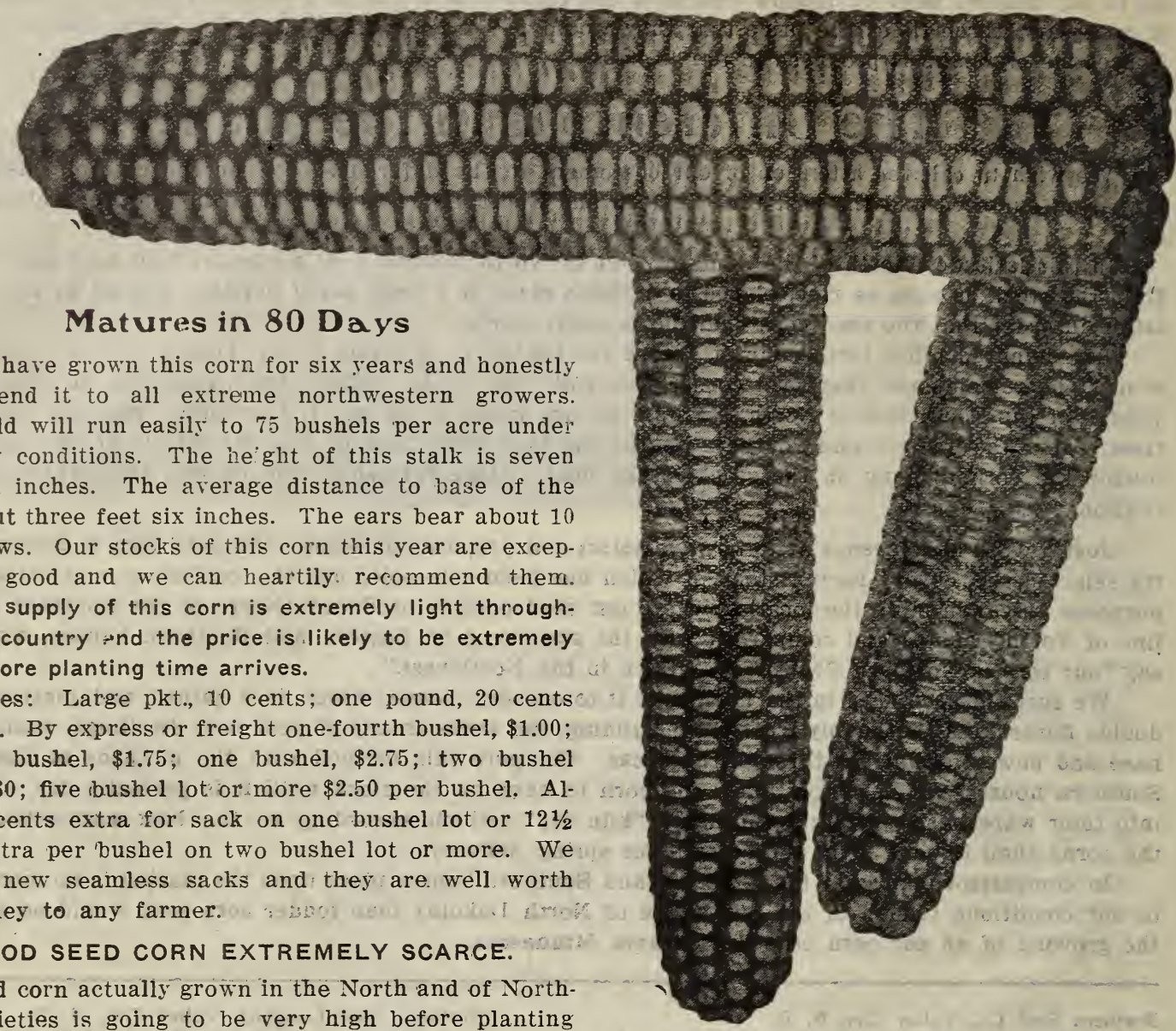

We have grown this corn for six rears and honestly reccmmend it to all extreme northwestern growers The yield will run easily to 75 bushels per acre under ordivary conditions. The he ght of this stalk is seven feet, six inches. The arerage distance to base of the ear alout three feet six inches. The ears bear about 10 to 11 lows. Our stocks of this corn this year are exceptionally good and we can heartily recommend them. But the supply of this corn is extremely light through out the country $\rightarrow$ nd the price is likely to be extremely high before planting time arrives.

Prices: Large pkt., 10 cents; one pound, 20 cents postpaid. By express or freight one-fourth bushel, $\$ 1.00$; one-half bushel, $\$ 1.75$; one bushel, $\$ 2.75$; two bushel lots, $\$ 2.60$; five ibushel lot or more $\$ 2.50$ per bushel, $\mathrm{Al}$ low 25 cents extra for sack on one bushel lot or $12 \frac{1}{2}$ cents extra per bushel on two bushel lot or more. We ship in new seamless sacks and they are. well worth the money to any farmer.

\section{GOOD SEED CORN EXTREMELY SCARCE.}

Seed corn actually grown in the North and of North ern Varieties is going to be very high before planting

time. We guarantee the prices in this catalog on seed corn until March 1, 1910, as long as our stocks last. After March 1st, we reserve the right to raise the price if we see fit. Get your order in before March 1st, and it will be filled at these prices.

\section{North Dakota Golden Dent}

Highly recommended by the Experimental Station of North Dakota. A yellow Dent corn, a deep kernel corn, which matures with reasonable certainty in North Dakota. This corn, as its name signifies, is a yellow dent corn, very early and an average yielder. Our stock of North Dakota Yellow Dent was obtained three years ago from the Experimental Station. Since then we have selected for earliness, de tasseling for barren stalks and otherwise improving upon it unt 1 we have the best quality of Yellow Dent corn there is obtainable to plant in the latitude of North Dakota. Ears grow well up off the ground, and can be cut with a harvester, but the ears are not so large as the Northwestern Dent Corn. Price Golden Dent Corn:

Large pkt., 10 cents; one pound, 20 cents, post-paid. By freight or express, one bushel, \$3.00; two bushels at $\$ 2.90$ per bushel; five bushels or more, $\$ 2.80$ per bushel. On one bushel lot allow 25 cents extra for sack. On two bushel lot or more, allow $12 \frac{1}{2}$ cents extra per bushel for sacks.

Nerthern Seed Co., Valley City, N. D.

Gentlemen: As manager of the Nester Farm, I have planted all the way from 50 to $7 \tilde{j}$ bushels of your Northwestern Dent Seed Corn for the last four years. It is with pleasure I recommend this corn to growers. It has always given us the best of satisfaction. We find that your corn ripens earlier and more eventy than corn we have bought from other seedsmen. You may count on us for a regular customer for this kind of corn in the future. Very truly yours, A. A. BOOTH. Manager Nester Farm, Valley City, N. D.

Northern Seed Co., Valley City, N. D.

Dear Sirs: We bought some of your Northwestern Dent Corn last year and we find it ripens 10 days earlier than corn we bought from another seed house the year before. You can rely upon. us for a steady customer.

JENS I. JOHNSON, Stutsman Co., N. D. 


\section{EXTRA EARLY MINNESOTAGNO. 13 CORN}

The best Early Dent Corn in Existence. No Yellow corn approaches it for earliness of yleld. It Is. adapted to a great variety of soils and climate.

The ears are of handsome appearance bearing 16 to 20 rows of bright, rich yellow, smooth, wedge-shaped kernels packed closely on the cob from butt to tip. the ears average eight inches in length and are borne usually two on a stalk. No corn excels in quality the Minnesota No. 13 ; the cobs are well filled and the individual kernels plump and of good color.

Minnesota No. 13 thoroughly matures in ninety days when planted on favorable soil and in a good location, but ninety-five to one hundred days places it out of danger under average conditions. A variety of corn which will show such valuable characteristics is an acquisition on any farm, especially for planting in the Northwest where early frosts are common. It may be planted as late as the second week in June and yet safely mature a crop.

Another point to which particular attention should be directed is its adaptability to changes in soil and climate. Many varieties fail to do well when subjected to new conditions or require several years to become acclimatized. Minnesota No. 13 Corn, however, will thrive and produce abundantly on most any soil and will do remarkably well under adverse conditions when other varieties would fail entirely.

The stalks grow to a height of seven feet and being leafy make excellent and very nutritious fodder.

Prices: One peck, $\$ 1.00$; one-half bushel, $\$ 1.50$; bushel, $\$ 2.60$; five bushels, $\$ 2.50$ per bushel; ten bushels, $\$ 2.40$ per bushel. New seamless sacks extra at 25 cents each.

\section{North Dakota Yellow Dent}

This corn is a very early yellow dent, but not so true to type as the Minnesota 13 . We can recommend planting it somewhat farther North than Minnesota 13, but we have not developed it so highly as the Minnesota 13.

Prices: By express or freight, one peck, $\$ 1.00$; half bushel, $\$ 1.75$; one bushel, $\$ 2.75$; five bushels or more, $\$ 2.60$ per bushel. Allow 25 cents extra for sack on single bushel lot, or $121 / 2$ cents per bushel on two bushel lot or more. We ship in new seamless bags.

\section{GOOD SEED CORN EXTREMELY SCARCE.}

Seed corn actually grown in the North and of Northern varieties is going to be very high before planting time. We guarantee the prices in this Catalog on Seed Corn until March 1st, as long as our stocks last. After March 1st, we reserve the right to raise the prices if we see fit.. Get your order in before March 1 st and it will be filled at these prices.

Northern Seed Company, Valley City, N. D.

Gentlemen: Having received Seed Corn from you last year I wish to say that I am very well pleased with the seed. It will yield better than forty bushels to the acre and is good solid corn. Thanking you for past favors, I remain,

MURRAY PACK, Bryant, S. D.

Northern Seed Company, Valley City, N. D.

Gentlemen: I was somewhat disappointed by the looks of the Corn I bought from you last spring as it was not very "showy" looking, but after testing it I found it to be good seed and in the field it showed even better for it did not miss a hill. Wishing you success, I remain,

Yours for business,

FERD HAMMERMEISTER, Wahpeton, N. D.

Northern Seed Company, Valley City, N. D.

Gentlemen:- The Seed Corn I got from you last spring is all right and is going to get ripe in good season. When I need more seed you will get my order.

L. G. TORGERSON,

Hays, S. D., Box 46.

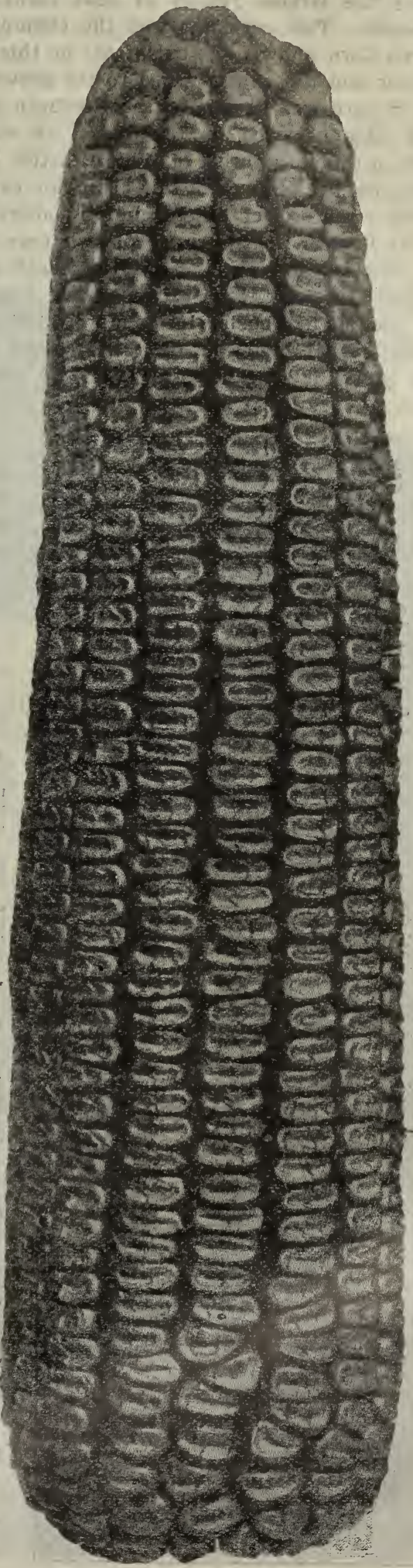




\section{Pedigreed White Rustler Corn}

This is the earliest white dent corn known. It is likely the largest yielder of dent corns for Northern Growers. This corn has won the championship at the Fargo Corn Show. See cut of ear on this page also the grower and the cup awarded to the grower. Champion ear of corn was bought by the Northern Seed Company at a fabulous price, for the reason we wanted to get a start in the very purest of White Rustler Varieties. We offer now the produce of this champion ear of corn. Remember there is no other genuine pedigreed acclimated White Rustler Dent Corn, except what we offer you.

Price: One peck, $\$ 1.00$; one-half bushel, $\$ 1.50$; single bushel lot, $\$ 2.75$; two to five bushel lots, $\$ 2.60$ per bushel; five bushel lot or more, $\$ 2.50$ per bushel. On single bushel lots allow 25 cents extra for sack. On two bushel lots or more allow $121-2$ cents per bushel extra to cover cost of sacks.

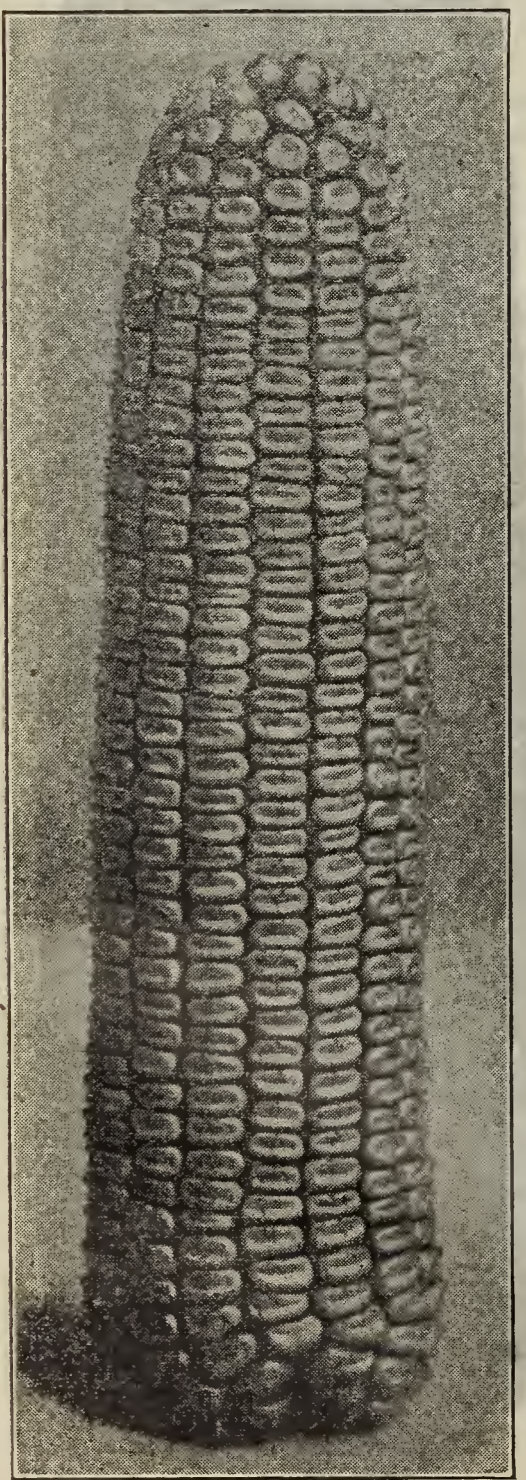

Champion Ear Corn

We ship in new seamless bags. They are worth the money.

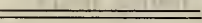

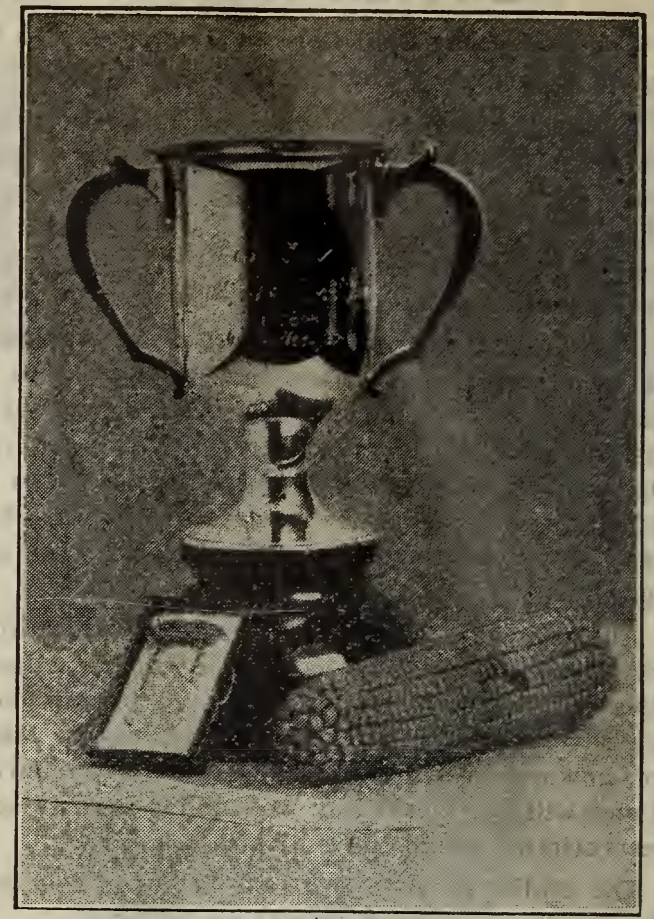

Cup Given Grower of Champion Ear of Corn SAYS OUR NORTHWESTERN DENT CORN IS AS EARLY AS
SQUAW CORN.

Northern Seed Company, Valley City, N. D.

Dear Sirs: I wish to say the Field Peas ordered from you did very well I planted them the 9th of April and find they are not hurt by any of the frosts we have had here in the spring. The seed corn germinated well. I think the Northwestern Dent is ahead of the Improved Squaw as it grows more fodder and has larger ears, up farther from the ground. They both seem to ear out about the same time,

Yours truly,

Northern Seed Company, Valley City, N. D.

Gentlemen: The seed I ordered from you last spring was $O$. K. I secured. a good stand of Northwestern Dent Corn. I gave my neighbor half that I bought and he also got a good stand. The peas were good, we had all that we sould use. I am well satisfied with the goods you sent me. You will have my order for seeds again. Yours truly, FRED NELSON, LEHR, N. D.

Northern Seed Company, Valley City, N. D.

Gentlemen: I am very much pleased with the Seed Corn I bought from you. The early part of the season was very unfavorable and a large part of the corn in this vicinity was thin, in some cases fully a third of the seed failed to grow. In the field I planted with your seed there were no blanks. The plants came up soon and were vigorous. Yours truly,

Glen Ullin, N. D.

Northern Seed Company, Valley City, N. D.

We wish to congratulate you on the Northwestern Dent Seed Corn you sold us last year. We got a very good stand. and find that it ripened very early, and evenly. In fact your Northwestern Dent Corn ripens earlier than corn that I bought from other seedsmen and sowed on my farm. This evidently shows that the rigid selection you are giving your corn begins to tell. Yours truly,

FRANK SANFORD,

Rogers, N. D.

Northern Seed Company, Valley City, N. D. Gentlemen: The Seed Corn I got from you was good. I planted it May 2nd and now it is ripe, good and hard, so I am well pleased with it. Yours truly,

Sept. 7. T. H. THOMPSON, Enderlin, N. D.

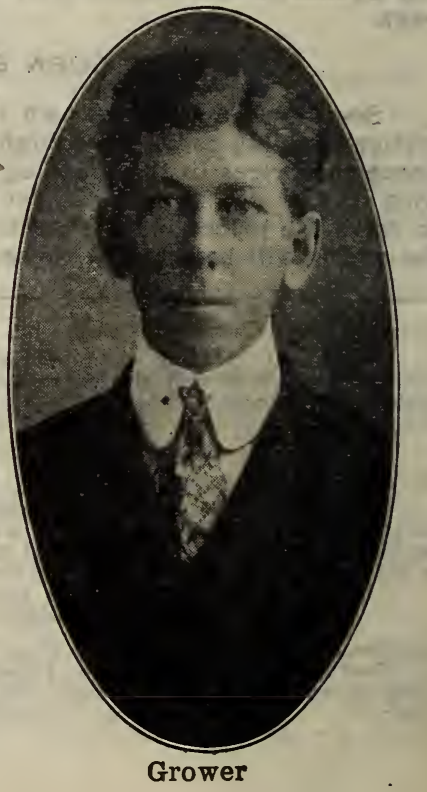




\section{EXTRA EARLY FLINT SEED CORN}

These are the earliest varieties grown and are especially adapted to Northern conditions. They make a rapid growth, ma ture quickly and under favorable conditions yield immeneely. All are perfectly aeclimated to our Northern conditions, which mean cool nights and short summers. The "Squaw" types of the flint corns are extremely early, but the ears grow so close to the ground that they cannot be harvested with a corn harveater, hence are most valuable to "hog off" by turning stock into the fields and thus allow them to harvest the crop. The Mercer. Triumph, Longfellow, King Philip, and Smut Nose are also much used for replants where the first plantings fail, also for late fodder on early summer fallowo-native sod, and the new comer used for replants where the first plantings fail, also for late fodder on early summer fallowo native sod, and the new comer
on the frontier can grow fodder from late plantings cheaper than he can make hay, thus providing a grain ration for the stock.

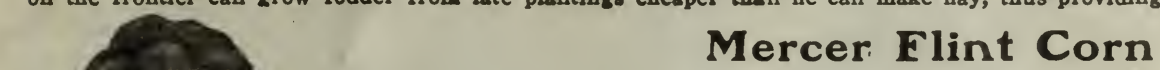

Mercer is one of the best flint corns known. It grows well up on the stalk, yields about 20 per cent more than Gehu and is practically as early. Price: One half bushel, $\$ 1.50$; one bushel, $\$ 2.60$; five bushels or more, $\$ 2.55$; ten bushels or more, \$2.50. We ship in seamless sacks at 25 cents each. They are well worth the money.
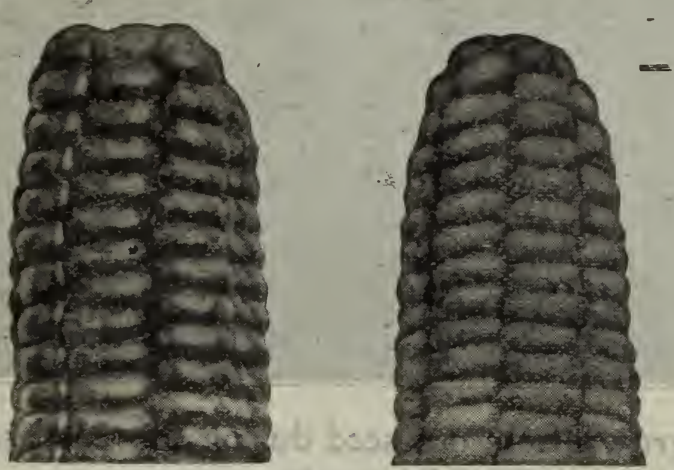

Plant Flint Corn and be sure of some.winter, feed

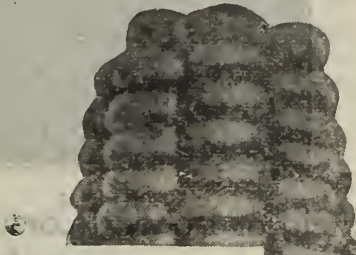

Improved King Phillip. (Extra Early Red Flint.) An old-time New England favorite perfected by us. -Extremely hardy. One of the best and most reliable early sorts. Ears 10 in. long; very early. Large pkt., $10 \mathrm{c}$; pound, 20c, postpaid.

By express or frieght, one-fourth bushel, $\$ 1.00$; one-half bushel, $\$ 1.50$; one bu., $\$ 2.60$; five bus., $\$ 2.55$ per bu.; ten bus., $\$ 2.50$ per bu. Sacks extra $25 \mathrm{c}$ each.

North Dakota Yellow Flint. (Gehu.) resembles closely the White Flint in earliness, habit of growth, etc., but the grain is yellow. Average height stalk 5 feet, average distance kase of ear from ground, $11 / 2$ feet. Average length of ear 8 inches. Large pkt., 10c; pound, $20 \mathrm{c}$, postpaid. One-fourth bushel, $\$ 1.10$; one-half bushel, $\$ 1.60$; one bushel, $\$ 2.65$; ten bushels, $\$ 2.60$ per bushel. Bags extra, $25 \mathrm{c}$ each.

North Dakota White Flint. Resulting from a careful selection of Squaw Corn for many years. Very much better than the Squaw. Average height of stalk 5 feet. average distance base of ear from ground $11 / 2$ feet. Average length of ear 8 inches. Large pkt., 10c; 1b., 20c, postpaid. One-fourth bushel, $\$ 1.10$; one-half bushel $\$ 1.60$; one bushel, $\$ 2.65$; ten bushels, $\$ 2.50$ per bushel. Bags extra, 25c each.

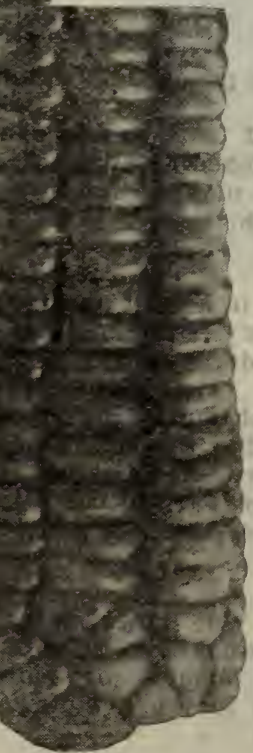

King Phillip

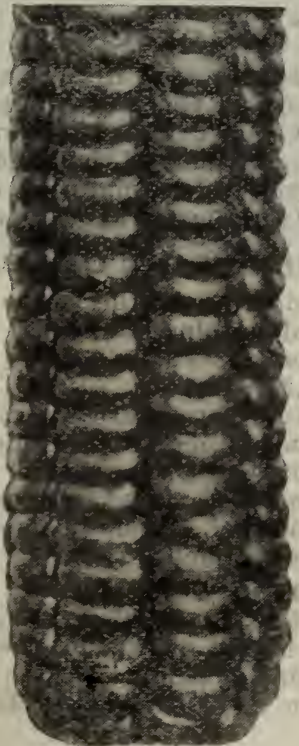

Mercer

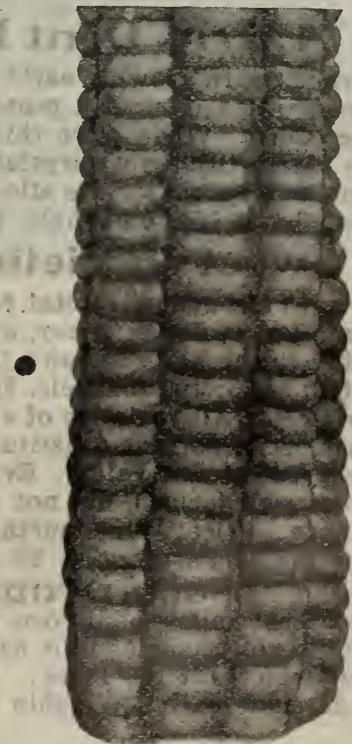

N. D. Yellow Flint

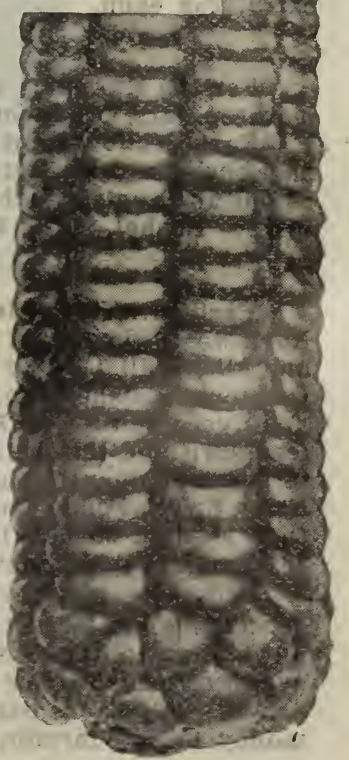

N. D. White Flint 


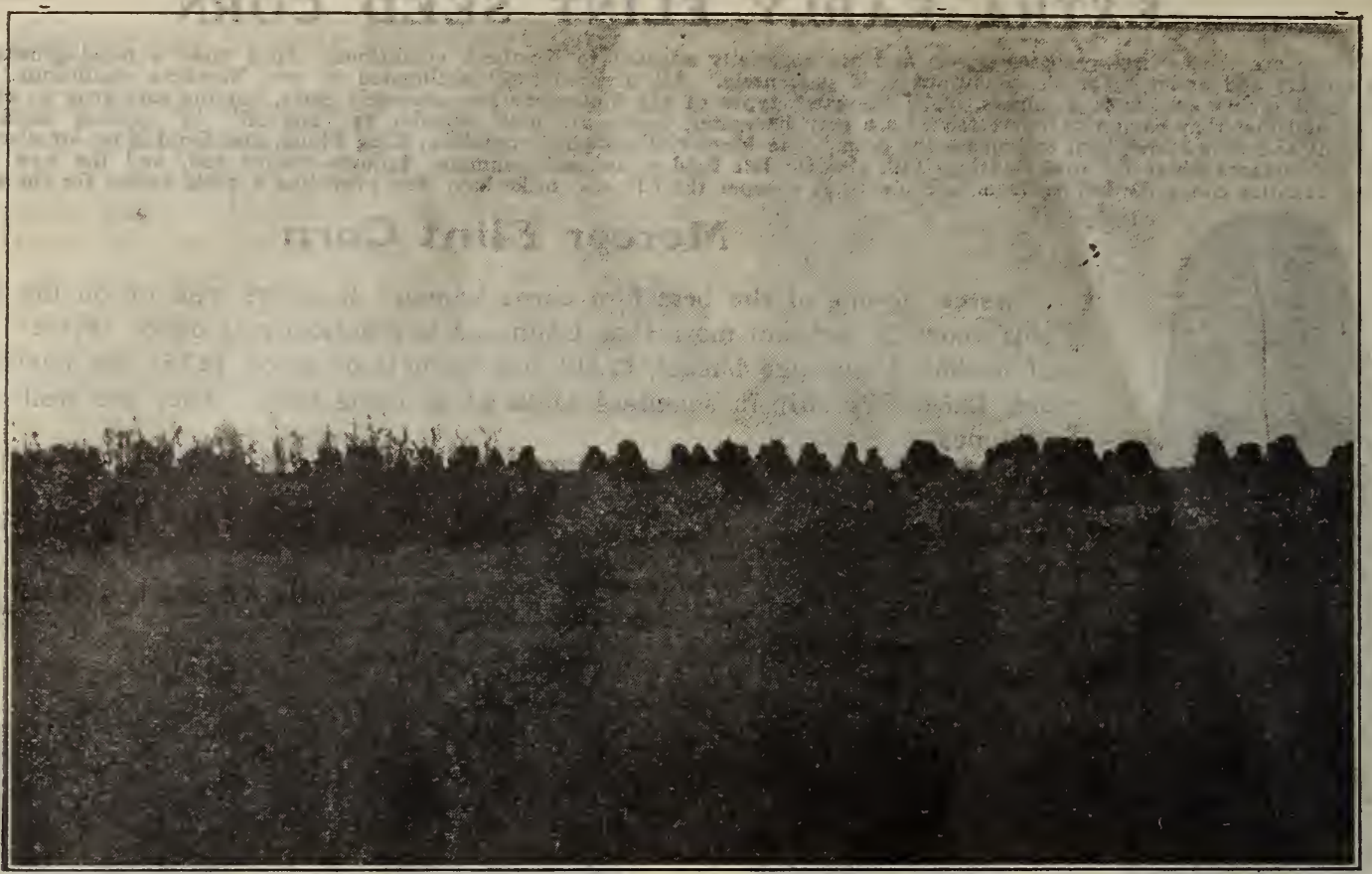

Field of Fodder Corn grown from our seed during the past season. Don't you wish you had this to feed during the coming winter months?

\section{Medium Dent Fodder Corn}

There are many who prefer for fodder smaller growing corn than the large and later varieties, claiming for it the following advantages: Ist, that it is more readily handled by the corn harvester, or even the zrain binder; 2nd, that it matures earlier, and gives well formed and often partially or fully ripened ears; 3rd, that it is more easily cured; 4 th, that the smaller stalks make finer and richer fodder; 5 th, that the fodder is more easily handled in putting through the silage or fodder cutter, or if fed long, is miore eastly handled in the manger.

Elephant Fodder Corn. We believe this variety will best please the advocates of the type of corn above referred to. It is tall growing, averaging 7 to 8 feet. It is very leafy. It has a small stalk. It will 1orm, even in Northern Minnesota.and in North Dakota, good sized ears, thus adding to its feeding value. It is low in price. Drill in rows about $3 \frac{1}{2}$ feet apart, and about 60 pounds to the acre. Price: Bushel, \$1.40; two and one-half bushels, $\$ 3.25$; ten bushels, $\$ 12.25$. Write for special price on large lots Sacks extra, 25s each.

\section{Eàrly Dent Fodder Corn}

For the silo many stock raisers are growing early dent corn as it gives a large proportion of fairly well matured ears, producing a feed which is rich in protein and very nutritious.

Early Yellow Dent Fodder Corn. When sown thickly in drills, at the rate of from one to one and a half bushels to the acre, this seed will give a surprising amount of rich feed, relished by all stock. It can be cut and run through an ensilage cutter for the silo just before maturity or it may be fed in the rack. Price: Bushel, $\$ 1.55 ; 21 \frac{1}{2}$ bushels, $\$ 3.65 ; 10$ bushels, $\$ 14.00$. Sacks extra, 25c each.

\section{Sweet Varieties For Fodder}

Early Sweet Fodder Corn. This makes capital fodder, and will mature ears in almost any part of the Northwest. The stalk is small, but sweet as honey, and nothing can make better feed than this, fed ear and all. Drill $11-2$ to 2 bushel to the acre, in rows just far enough apart to admit cultivation. Price: One-fourth bushel, $65 \mathrm{c}$; bushel, $\$ 1.75$; two bushels, $\$ 3.25$.

Evergreen Sweet Fodder Corr. All varieties of sweet corn possess very much more "sugar" than any feed sort, and this being the most important constituent, it necessarily follows that the corn holding this in greatest quantity has the greatest net value. Evergreen Sweet Fodder grows much taller than the Early Sweet Fodder and makes well formed, but not matured, ears in almost any part of the Northwest. Drill $1 \frac{1}{2}$ to 2 bushels to the acre. Price: One-fourth bushel, 75 cents; one-half ibushel, $\$ 2.25$; five bushels, $\$ 2.15$ per bushel. New seamless sacks extra at 25 cents each.

\section{GIANT FODDER CORN}

This is the largest and coarsest yellow dent corn that we handle. It makes, very large stalks and is unweilding to handle and we do not recommend it as highly as we do the other kinds of corn. However we furnish it for parties who want it. Price: One bushel, \$1.25; five bushels or more \$1.15 per bushel. Sacks extra at 25 cents each. We ship in new seamless sacks and they are well worth the money to any farmer. 


\section{NORTHERN GROWN SEED POTATOES}

CHANGE OF SEED.

It is very necessary from time to time for the potato grower who intends to make money growing potatoes to change his seed and be in shape to furnish straight lots of marketable stuff. Knowing it to be a fact that it is necessary for growers to change their seed; we have equipped ourselves with the very best equipment for handling this branch of the seed trade. We will endeavor at all times to keep the very best stocks of the standard varieties. At no time do we intend to put on the market an old variety under a new name as a great many seedsmen do. Our object is to handle the best of the tried varieties. In potatoes we handle nothing but North Dakota stock which is unsurpassed by any other.

\section{DATE OF SHIPMENT.}

Potatoes will be shipped at any date ordered, but where no special shipping date is named, we will use our own judgment, and ship as soon as danger from frost is over. Our prices are based upon prices prevailing, for equal grades of stock, when this catalogue goes to press. As the season advances the price may advance. If it does we will change our prices. We make special prices to carload buyers.

Culture (By Prof. Thos. Shaw): Potatoes grow best in a rather cool climate, and in a moist loam soil. The aim should be to put them on clover sod land, thoroughly pulverized, and to avoid planting them twice in succession on the same land, because of the danger of scab. To prevent scab it may be well to treat the seed with formaldehyde. The ground should be thoroughly and deeply pulverized. The crop is usually planted in drills three to five inches deep and from three to three and a half feet distant. Medium sized tubers are sometimes planted whole, but more frequently the good sized tubers are cut into large pieces. They are planted from 15 to 21 inches distant, but usually not more than 18 inches. The seed is cut, frequently by hand, but sometimes with machine slicers, and is planted by hand or with a planter. The harrow should usually follow the planting and again, and perhaps again, after the potatoes are up, and subsequently the cultivator should be frequently used.

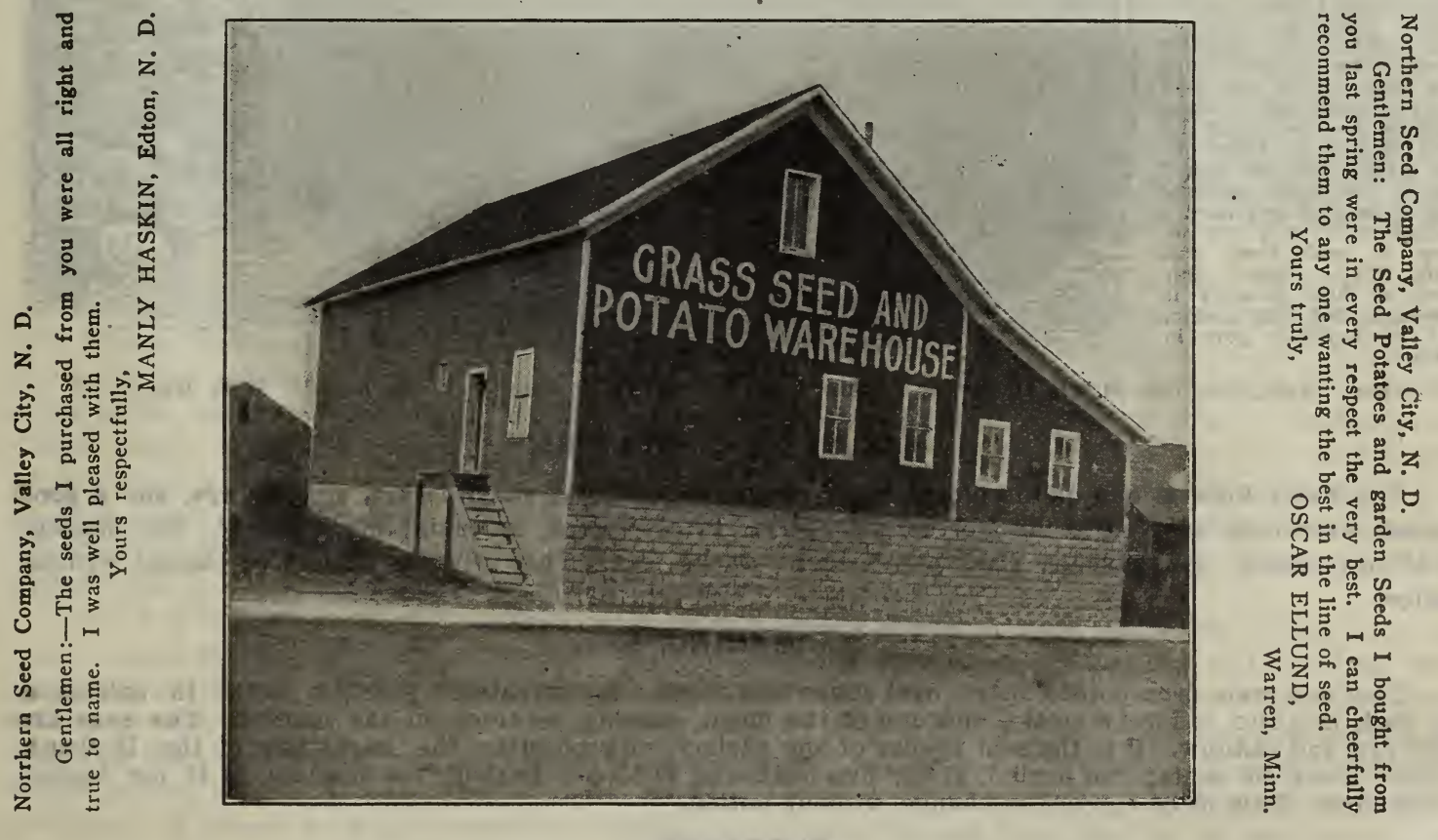

Northern Seed Co., Valley City, N. D.

Dear Sirs: We planted our garden with your Early Six Weeks potatoes. We have planted Six Weeks Potatoes before, but your potatoes seem to be the earliest we have ever raised. Our potatoes were ready for table use July 1st. You will certainly find your Six Weeks Potatoes in our garden hereafter. Yours respectfully,

MRS. W. A. DeSMET, Grand Forks, Co., N. D.

Northern Seed Co., Valley City, N. D.

Dear Sirs: Last year in May we planted some of your Majestic potatoes, having got them as a special favor through your manager, as they were not on the market last year. We your manager, as they were not on the market last year. We
find they are earlier than the Early Ohio, and a smoother lot find they are earlier than the $E$
of potatoes $I$ have never seen.

C. P. DANIELS, Richland, Co., N. D.
Northern Seed Co., Valley City, N. D.

Gentlemen: I am certainly satisfied with your seeds. The Early Ohio Potatoes we bought from you yielded an enormous crop of excellent quality. We shall order our seeds. from you next year. Yours.

GUY CORTLANDT, Pembina Co., N. D.

Northern Seed Co., Valley City, N. D.

Dear Sirs: This is our first year in your state and we prepared a gorden as that is all the farming we could do being on a homestead and having littde to work. Our garden grown from your seeds, together with our two cows, and grown from your seeds, together with our two cows, and $\$ 100.00$ out of our agrden, about one-fourth of an acre. The
quality of your seeds had a great deal to do with our suc cess.
MRS. JOHN M. HOUSE,

Billings Co., N. D. 


\title{
Early Ohio Potatoes Our Specialty
}

\section{ALWAYS $\square R E L I A B L E$}

\begin{abstract}
This grand old reliable potato is too well known to require any lengthy description. Almost every farmer and potato grower has given it a trial, and where true genuine stock was secured it has always given the best of satisfaction. No matter how many new early varieties are introduced the Early Ohio holds its place at the head of all other early sorts. We have more calls for it than any other variety. Carloads of this standard early variety are shipped every year to Southern States for seed purposes and the product thereof is shipped back again to our largest potato markets. The Southern potato grower realizes by planting our extreme Northern grown Early Ohio he will have his crop ready at least two weeks earlier than if planted from home grown seed. Our North Dakota grown Early. Ohio is vigorous and healthy, will naturally produce the largest crops and mature fully ten days to two weeks earlier than such as are bought up by seed dealers in large cities, where they are picked up in the open markets, and as long as they have a reddish color and an oblong or oval form, call them "Early Ohio." Our stock of these potatoes is extremely fine this season, and is absolutely pure in variety.
\end{abstract}

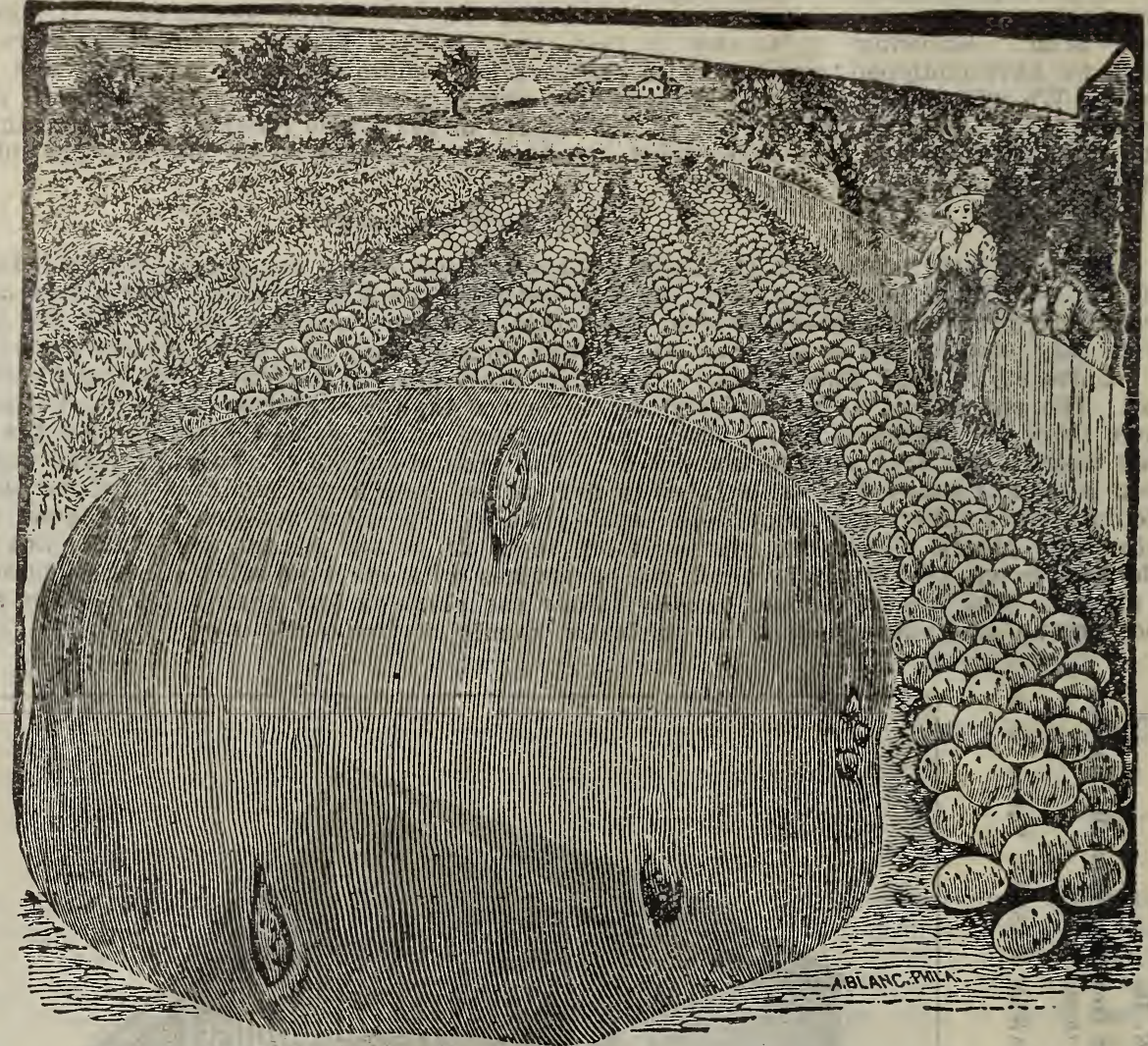

Prices: Peck, 50c; one bushel, $\$ 1.60$; five bushels, $\$ 1.50$ ten bushels or more, $\$ 1.40$ per bushel. Sacks free.

\section{EARLY ROSE POTATOES.}

The Early Rose is one of the oldest types of potatoes. Long, smooth skin, shallow eye, and a good keeper, especially adapted to the Northern country. Price: Peck, 50 cents; bushel, $\$ 1.65$; five bushels, $\$ 1.55$ per bushel; ten bushels, $\$ 1.45$ per bushel. Sacks free. This price is subject to change without notice.

\section{CARMAN NO. 3.}

This is a main crop potato, large, oval shape and likely the greatest yielding potato in exdstence. Its flesh is white and very mealy, and one of the finest cooking potatoes on the market. The ores are very few and shallow. It is the best keeper of any variety with possibly the exception of the Burbank. Price: Peck, 50 cents; one bushel, $\$ 1.65$; five busheels, $\$ 1.55$ per bushel; ten bushels, $\$ 1.45$ per bushel. Sacks free. This price subject to change without notice.

\section{BURBANKS.}

A long, white jotato, shaped something like the Early Rose. A main crop potato, a good ylelder and in a standard sort in all the big potato markets. Prices: Peck, 50 cents; bushel, $\$ 1.65$; five bushels, $\$ 1.55$ per bushel; 10 bushels, $\$ 1.45$ per bushel. Sacks free. This price subject to change without notice.

Northern Seed Co., Valley City N. D.

Dear Sirs: We wish to thank you for our success in gardening. We surely had fine crops from all your seeds. Respectfully yours, CHAS. M. BROWN, Custer Co., Mont.

Northern Seed Co., Valley City N. D.

Gentlemen: Please send me your 1911 catalog. I want to order some early garden seeds and would rather have your seeds than any others I have every used. I have better luck with your seeds than with those from Eastern houses. Yours truly,

MRS. CLY'YE BENTLEY, Park Co., Wyoming.
Northern Seed Co., Valley City N. D.

Gentlernen: My order has been received. Everything in good condition and of good quality. I can say the same of all previous orders you have sent me. Yours respectfully,

MRS. T. L. LAMBERT, Custer Co., Montana.

Northern Seed Co., Valley City N. D.

Dear Sirs: I had good luck with all the seeds I pur. chased from you especially the Fishe's Tomato. We had ripe tomatoes this year for the first time since we came to $\mathrm{D}_{2}$. kota. MRS. RUBY BROWN, Hettinger County, N. D. 


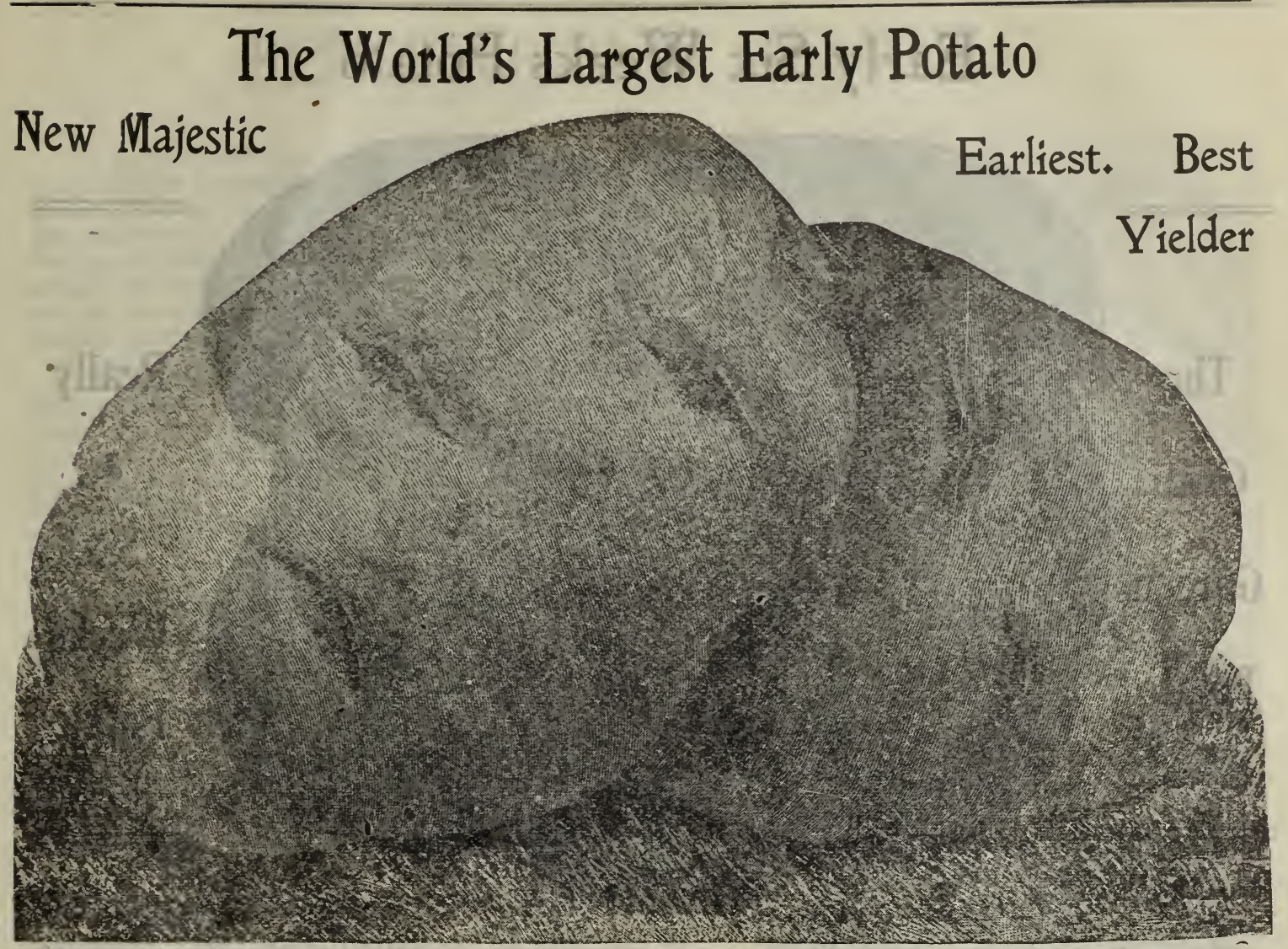

The Largest, Handsomest, Smoothest and Best Flavored Early Potato in the World. Never before In the history of the potato world has there'been such an enormous yielding Extra Early Potato introduced. The Finest, Grandest and Most Up-to-date Early Potato ever offered, now introduced for the first time. As modest as we are, we cannot restrain our enthusiasm. It's a beauty such as you never saw belore. None in the wide world its equal. It stands alone; The Great Majestic all purpose potato. Listen, Read, Order, Plant. Make money while you can. Here is your opportunity. We wish we had space to tell Jou all we know about this wonderful Large Early Potato. It is indeed th? most handsome potato ever dis covered. Just the right shape; just the.right size. In fact, it is the ideal of all varieties. No potato is superior in eating qualities year in and year out. It stands to other potatoes as rich Jersey cream does to skimmed milk. As early as the earliest, and is better than the b=st.

It is a potato ve know will not only make dollars for the grower, but will please him beyond dopbt as well. A striking characteristic of this new Majestic beauty is its productiveness. We will say right here that it will yield you more big fine potatoes by far on the same amount of ground than any other sort ever before discovered. What more can we say? Need we say more. Our plea with you is to plant freely of this new potato. You will find it the most profitable potato you have ever planted. We know you will thank us and become as enthusiastic as we when once you see the fine potatoes and enormous yleld it produces. We know we will be unable to supply the enormous demand there will be for this new potato the coming season. If you are not ready to order your seeds now write us how many to reserve lor jou, making remittance to cover half your order; then when they can be shipped safely without danger of Ireezing send balance, and seed will be sent promptly and at once. Price: Peck, 60 cents; bushel, $\$ 1.75$; five bushels, $\$ 1.70$ per bushel; ten bushels, $\$ 1.60$ per bushel. Sacks free.

Northern Seed Co., Valley City, N. D.

Gentlemen:-We wish to thank you for returning our money and telling us the seed that we had ordered you did not consider up to standard, consequently, you did not fill not consider up to standard, consequently, you did not fill
our order. We consider this the proper course for you to take and most heartily thank you for taking care of our interests and not sending us something that had foul seed in it. There is no question but that this treatment to your customers will build up a large seed business.

J. K. SUMMERS, Wells Co., N. D.
Northern Seed Co., Valley City, N. D.

It is with considerable chagrin the seed business we have given you in the past has not been all of our order. We have divided our business amongst several seed firms but we have found that you have given us the best service and the best seed for the money. You have always treated us fairly and we want to inform you in the future you will have our entire seed business on all my farms.

P. P. PERSONS, Valley City, N. D. 


\section{PEDIGREED OATS AND WHEAT}

It is with pleasure that we offer to our customers our stocks of Pedigreed oats and wheat. We have now been in the seed business six years, and it has taken us just six years to get into shape to offer our customers Pedigreed Oats and Wheat. We have used the greatest care in the selection and breeding of these seeds, and we are satisfied they will be of untold beneflt to our farmer friends.

The prices on these Pedigreed Seeds are necessarlly high on account of the care and time it takes to produce them. One item of expense we mention so that our customers will see what we have to go through in order to produce this seed. Our Oat stocks for seed last year cost us in freight and duty over $\$ 11.00$ per acre. Part of this seed was procured in Germany, part of it in England and part of it in Canada. Then of course, as you know, we only take a portion of the crop for seed. Although we price this seed cheaper than is priced ordinarily, we have to have a fair price for it. Neither do we expect farmers to buy a large amount of it. Take our Oats for instance, two acres planted now on good land and properly taken care of, would produce enough in two years to a great deal more than seed what would be wanted for the average farm. Our idea in offering these oats and wheat is, to provide a way whereby the critical farmer can procure for his seed plots stocks of wheat and oats which are absolutely reliable.

\section{Re-Generated Swedish Select Oats, Celebrated for their Thin Skin, Earliness, Strongness of Straw. The Heaviest Yielding Oat in Existence}

These oats are the product of seed we imported trom England purchased from Garton, the celebrated seed breeders of England. We allow them to go through no one's hands, except our own, and planted them on the heavy clay soil of Northwestern North Dakota. We have not clipped these oats. Clipping oats adds nothing to the quality of the oat but does make them look better, consequently deceives the purchaser. The product from these oats will be the same as the seed you receive from us. Our seed is absolutely free from foul seed of any kind.

Do not confuse these oats with the ordinary oats sold as Swedish Select. These are the Regenerated Swedish Select Pedigreed Oats. Price. One peck, 60 cents; half bushel, \$1.15; one bushel, $\$ 1.75$; two and onehalf bushels, $\$ 4.00$; ten bushel lot or more, $\$ 1.50$ per bushel. Seamless sacks extra at 25 cents each.

\section{ORDINARY SWEDISH SELECT OATS.}

These oats are of the stock that is generally sold by seedsmen as Swedish Select. Our stocks are very clean and heavy.

Price: One bushel, $\$ 1.25$; two and one half bush els, $\$ 2.85$; five bushels, $\$ 5.50$; ten bushel lot or more $\$ 1.00$ per bushel. Write for prices on larger quantities.

Northern Seed Co., Valley City, N. D.

Dears Sirs: We planted some of your 60 day oats last year and wish to heartily recommend them to any one want. ing an extremely early oat. They are very nearly as early as the wild oats. WALTER ACKERMAN, Griggs Co., S. D.

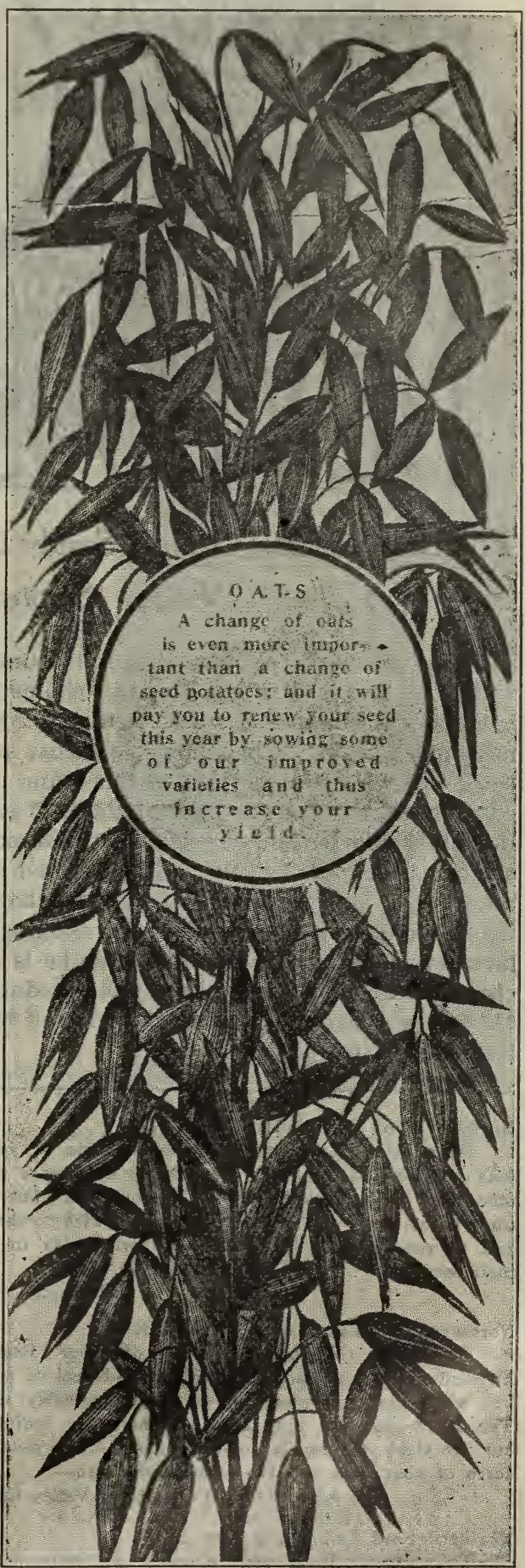

Northern Seed Co., Valley City, N. D.

Gentlemen: Last spring I purchased some vegetable seeds and also some flower seeds from you. I am happy to say they did splendidly, especially the Sweet Peas, which are perfectly beautiful. 


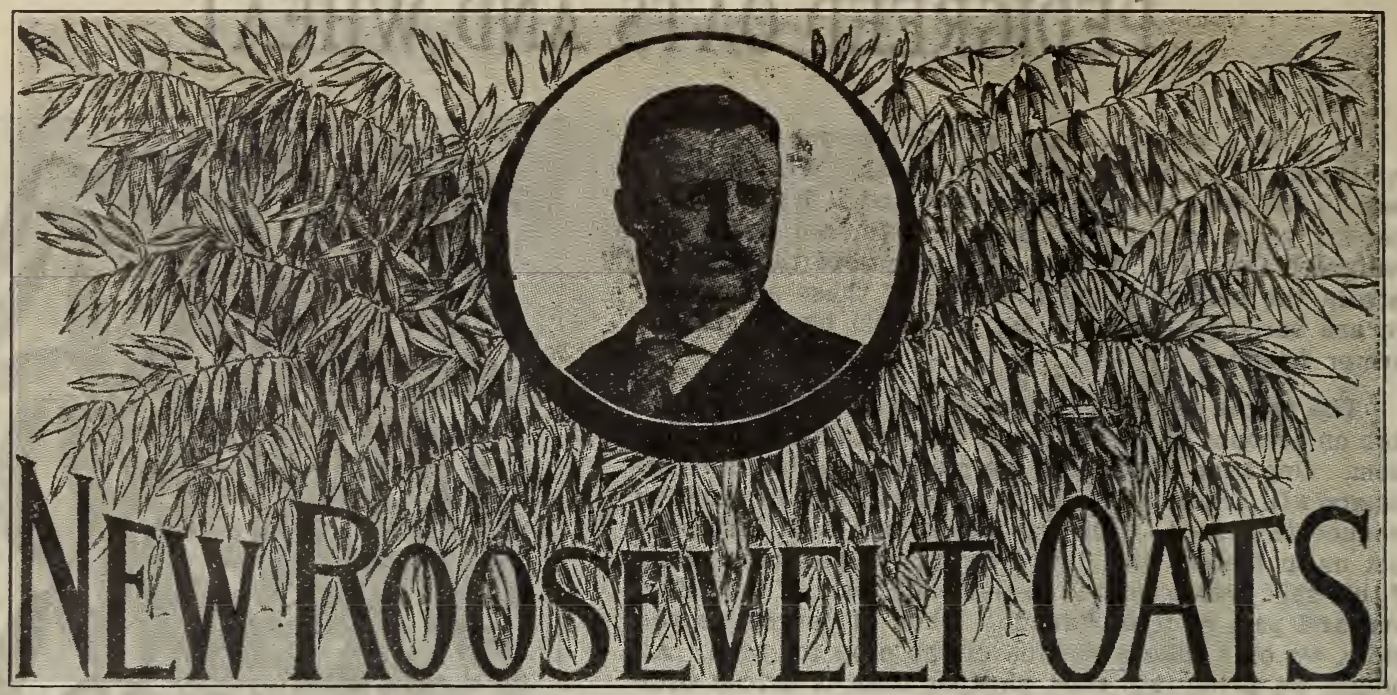

\section{The Best Yielding Oat on Sandy Loam Soil. Thin Skinned Oat of High Feeding}

\section{Value. Strong Straw, not Inclined to Lodge.}

This is one of the most Productive Oats that have been bred up in recent years. Our experience with it is, that it is all the producer claims for it and it is an oat that will yield at least four times as much as the common inbred oat, that is commonly sown. These oats will weigh from 40 to 50 pounds measured bushel. It is a fairly early oat and has a strong straw, not inclined to lodge. Our experience is, in the Northwestern part of this state, this oat is not inclined to rust. These oats will not be shipped out clipped, but in their natural state. "You know that clipping oats or taking off the short end makes them look shorter and chubby but it does not add to their usefulness. We are not inclined to deceive our customers in regard to these oats but wish to give them statements just as they are. When you receive an order of oats from us, you will find that the product from our seed will be fully as good as the seed itself. We do not blame anyone for clipping oats who believes in misrepresentation, but we feel that farmers should at least realize what he is getting when he buys his seed, and when anyone ships him clipped oats, he cannot tell what the product is going to look like: Price: Peck, 60 cents, one-half bushel, $\$ 1.15$; one bushel, $\$ 1.7 .0$; two and one-half bushels, $\$ 4.00$; ten bushels or more $\$ 1.50$ per bushel. New. seamless sacks extra 25 cents each.

Northern Seed Co., Valley City N. D.

Dear Sirs: Last year we planted some of your seed oats and we find the yield over 30 per cent more than any other oats we have. ever grown. Not only that, but the seed came to us clean and in fine shape. We wish to thank you, and to recommend your oats to all who wish to improve their seed. JAS. C. WATKINS,

Morton Co., N. D.

Northern Seed Co., Valley City N. D.

Gentlemen: We planted some of your Regenerated Swedish Select Oats last year with a good deal of misgiving, but when the crop came off we were agreeably surprised. The straw was not only stronger than our ordinary oats but the yield was nearly one-third more. The yield on two acres of your oats was 110 bushels per acre.

ALFRED G. CODDING, Valley Co., Mont.

Northern Seed Co., Valley City N. D.

Dear Sirs: It is with pleasure we recommend your Seed House for the reason the shipment of seeds we received far surpassed anything of the kind we ever had. The oats were perfectly clean and the product of the same was enough to give us entire new seed oats for the coming year. Yours truly,

OLAF JOHNSON, Big Stone Co., Minn.
Northern Seed Co., Valley City N. D.

Dear sirs: I am just cutting the oats I raised from your seed. I am getting about eight tons of straw per acre and the heads are well filled. They are giving a very good yield. Yours very truly, MORTON GANZ, Jackson Co., Oregon.

Northern Seed Co., Valley City N. D.

Gentlemen: I was well pleased with the Alfalfa seed I purchased from you in 1908. I have a good stand. I am no longer doubtful about alfalfa since using your seed.

Yours truly,

JAMES MORGAN, Ward County, N. D.

Northern Seed Co., Valley City N. D.

Gentlemen: All the seeds we bought from you are doing fine. : The oats and alfalfa are going to make a very good stand. Yours,

L. J. DEDRICK, Pembina Co., N. D.

Northern Seed Company, Valley City, N. D.

Gentlemen:-All the seeds sent me by the Northern Seed Company were first class. The Alfalfa Seed in particular is fine and a good stand.

Respectfully yours,

ALBERT RANKY, Fessenden, N. D. 


\section{President Oats}

\section{A Heavy Yielder on Light Soils}

Exceptionally Thin Skinned

Superior Quality for Milling

Excellent Quality of Straw

\section{DESCRIPTION}

Medium early and open head. Owing to its very thin skin, it is a most desirable variety for milling purposes.

This is the first season we are offering this new breed for general farm crop. An oat to meet the conditions that this new breed is intended for, has been a long felt want.

It is a very popular oat for sandy or light clay soils.

Experiments conducted with this oat, both on small and large scale, for the past four years, proved it to be especially adapted to our conditions.

. In these trials it has shown itself to be the equal of our Regenerated Swedish Select Oats as a yielder. This is the highest recommendation.

Thoroughly tested for a period of from three to five years.

\section{IT IS THE LIGHT SOIL OAT}

Prices: Peck, 60 cents; one bushel, $\$ 1.85$; two and one-half bushels, $\$ 4.25$; five bushels or more, -1.60 per bushel.

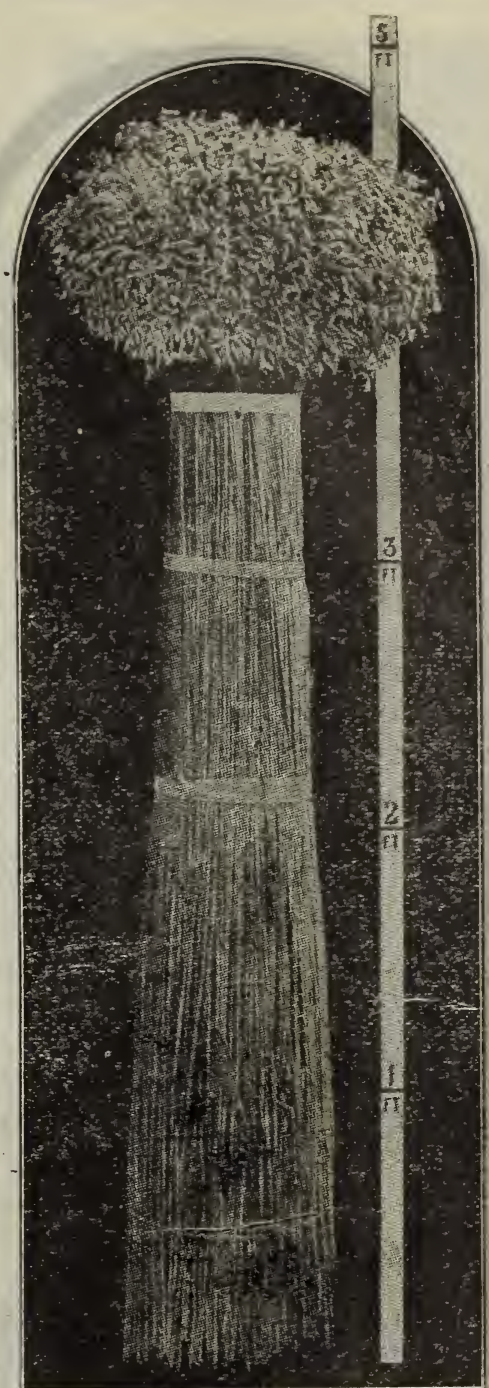

Northern Seed Co., Valley City, N. D.

Dear Sirs: I was well pleased with your "Home Grown" seeds last year. My crop of vegetables was just splendid and praised by everybody who saw them.

P. A. BATEMAN, Billings, N. D.

Northern Seed Co., Valley City, N. D.

Dear Sirs: The Red Weatherfield onion seed I got from you last year did extremely well. I like this variety. It is a good keeper and solid. I obtained 750 bushels last year from $11-2$ acres.

JOHN OPPEGARD, Williams Co., N. D.

Northern Seed Co., Valley City, N. D.

Gentlemen: I have used your garden seeds for three years and always had fine success with them; they are all that they are recommended to be and I do not think I could get better seeds anywhere.

MRS. L. B. LARSON, Pembina, N. D.

Northern Seed Co., Valley City, N. D.

Dear Sirs: The seed I received from you gave perfect satisfection. I had the finest garden I ever raised and can heartily recommend your seeds.

W. S. SMITH, Bowman, N. D.
Northern Seed Co., Valley Cityin. D.

Gentlemen: I used your seeds last year for the first time and consider them far superior to any I have ever used.

ILRS. JOHNSON, Ward County, N. D.

Northern Seed Co., Valley Eity, X. D.

Gentlemen: We have used your garden seeds now for four years in succession and after a careful investigation we find they are a great deal earlier than seeds we buy from Southern and Eastern Houses. IVe are satisfied this is caused by their being acclimated.

K. A. JORGESSON, Foster Co., N. D.

Northern Seed Co., Valley City, X. D.

Gentlemen: We came here last spring and settled on a homestead. We planted a garden using your seed for part of it, and the rest of the seed we got from a seed house in the east. We found your seed did much better in this climate than the other seed. The coming year we will not only buy our garden seeds froni you, but also what field seeds we buy our garden seeds fron you, but also
uours respectfully. Yours respectfully.
M. E. NELSON, Lyman Co., S. D.

Northern Seed Company, Valley City, N. D.

Gentlemen:-Thes eeds I got from you are fine. The Millet is good and both kinds of potatoes are more than fine." I am pleased with your seeds.

$$
\text { Yours, }
$$

- G. S. GAUL, Martin, N. D. 


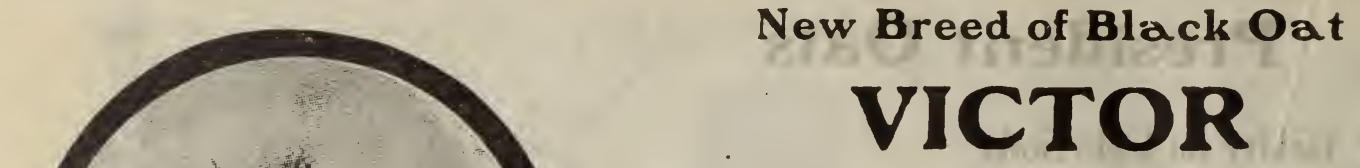

The Largest Black Grained Oat in Culttvation The Blackest Skinned Oat in Cultivation 25 Per Cent Stronger Feed than any White Oat

Description: Early, ear very open, pyramidal; Grain very large, of jet black color; Husk exceptionally thin; Straw strong and of the finest quality.

This new Breed of Black Oat was introduced by us last season for the first time. Its success (Season 1909) has been very marked.

Especially suited for very early sowing owing to its extreme hardiness.

It is entirely different from the old variety of Black Side Oats, as it has a much thinner skin.

It is entirely unique in respect to the amount of protein or flesh forming constituents which the grain contains, and which naturally makes it the most valuable oat for feeding purposes yet introduced, containing 25 per cent more oil than ordinary varieties of Black Oats and superior in every way to White varieties.

Price: One peck, 75 cents! half bushel, $\$ 1.25$; one bushel, $\$ 1.90$; two and one-half bushels, $\$ 4.35$; five bushel lots or more $\$ 1.60$ per bushel. New seamless sacks extra at 25 cents each.

Northern Seed Co., Valley City, N. D.

Dear Sirs: Iast spring I bought quite a number of seeds of different kinds, and I can truly say that they are the best garden seed I have ever planted, regardless of where they came from. I am going to plant more seed next spring, and I want your catalog, so I will be sure of getting good seed. If any one doubts this, just write to

I. B. HATFYELD, Highmore, S. D., Box 161.

Northern Seed Co., Valley City, N. D.

Gentlemen: The alfalfa seed I bought from you is all right. It looks to be a good stand so far. Yours truly, OLE BREDING, Powers Lake; N. D.

Northern Seed Co., Valley City, N. D.

Gentlemen: I wish to say that I am very much pleased with the seed I bought from you. I tried different kinds of seed from different companies this spring, but none growed so fast and sure as yours. I shall order my seeds from you in the future. Yours truly.

ALBERT KAÚPANG, Knox, N. D.

Northern S̈eed Co., Valiey City, N: D

Dear Sirs: The seeds yeb seHt, Hie this spring were all O. K., will say I have not had such à efóp for years.

I will send you a larger order next spring.

Yours truly,

D. B. OLSON.

Northern Seed Co., Valley City, N. D.

Dear Sirs: Last year we planted sone of your seed oats and we find the yield over 30 per cent more than any other oats we have ever grown. Not only that, but the seed came to us clean and in fine shape. We wish to thank you, and to recommend your oats to all who wish to improve their seed. Northern Seed Co., Valley City, N. D.

Dear Sirs: I am just cutting the oats I raised from your seed. I am getting about eight tons of straw per acre and the heads are well filled. They are giving a very good yield. Yours very truly,

MORTON GANZ, Jackson Co., Oregon.

Northern Seed Company, Valtey City, N. D.

Dear Sirs:-I am well satisfied with the Seed Corn se ceived from you. It has grown fine and will yield a soon crop this vear. I think it matures very early and is jus: what is warted in this northern country.

ID. F. WERTHMANN, Ipswich, S. D., Route 1.
Northern Seed Company, Valley City, N. D.

Gentlemen:-The seed I bought. from you last spring all grew and did well. The Corn is ripe and a good crop. I am sorry that I did not get more of the seed. The Peas were the best that $I$ ever planted, both in quality and cuantity. 


\section{OTHER GOOD SEED OATS}

On the Oats below, described on this page, we have good clean stocks, oats that were originally from pedigreed seed, but we have raised them two or three years here in open field work. Our stocks are clean and heavy and are a great improvement over the ordinary inbred oats that the farmer plants, but of course they are two years removed from pedigreed stock, whereas the stocks described on the four preceeding pages are actual pedigreed stock from a very close selection. You will note the difference in the prices between these oats and the Regenerated Swedish Oats, New Roosevelt, the President Oats and the Black Victor. The reason for this 1s, these oats are grown from pure seed but are field run seed, whereas the other oats are fully pedigreed.

WRITE FOR PRICES ON LARGE QUANTITIES. CARLOAD ORDERS SOLICITED ON OATS LISTED BELOW.

\section{New Sixty Day Oat}

The original seed of this valuable new oat was secured in Russia by the U. S. Department of Agriculture in 1901. On the seed sent by the Government to the South Dakota Experiment Station, that institution, in its Bulletin No. 96, makes the following report:

"With only two exceptions, every farmer to whom we have sold these oats is still growing it and is much pleased with it. It is similar to the Kherson Oats, which has been such a marked success in Nebraska, but it is adapted to a selection further north than that variety. In North Dakota the Sixty Day Oat has headed the list of varieties under trial for the last three years. It is a small, yellowish oat that weighs about 34 pounds per bushel. The hull is very thin, being easily shelled off in threshing if the concaves are set too close."

Price: One-fourth bushel, 50 cts; one bushel, $\$ 1.35$; two bushels, $\$ 2.50 ; 10$ bushels, $\$ 12.00$. Sacks extra 25 cts.

\section{New Kherson Oats}

One of the earliest oats in cultivation. It was introduced by the Experiment Station of Nebraska, and has proved a success in that state, being naturally adapted to sections that are subject to drought. It is a vigorous but not rank grower, producing shorter straw than other varieties, with branching heads and very broad leaves. The berries are light yellow in color, small, but numerous, and have a very thin hull. These oats usually weight well per bushel, and in this respect, as well as in productiveness, they are one of the best of the early varieties. Price: Peck, $40 \mathrm{c}$; bushel, \$1.25; two and one-half bushels, $\$ 2.85$; five bushels, $\$ 5.50$; ten bushels and more, at $\$ 1.00$ per bushel. Sacks extra 25 cents.

Black Beauty Oats. These oats make such a distinct advance over all other varieties, especially in point of productiveness and strength of straw, as to set them apart and above all other oats. They are in a class of their own, and in the particulars above mentioned are not approached by any other oat.

At the present time but few black oats are grown in America. Canada has found how good they are and is now growing them very largely. In most European countries they have decidedly the preference, and in England it is safe to say that three bushels of black oats are grown to one of thite.

They are preferred by those who have had experience with then principally on account of their superior yielding qualit:es, but besides being fully equal, if not better than white oats in point of feeding qualities, they possess another very valuable characteristic in the unequalled stiffness and strength of straw. Nothing less than a tornado or cyclone will lodge them.

Black Beauty Oats are the best of all black oats. They are early, the straw is exceedingly strong and vigorous, and the head is extremely long. On account of its remarkable stooling propensities two bushels are amply sufficient to seed an acre. Price: One-fourth 'bushel, 50 cents; one bushel, $\$ 1.3 \tilde{\text {; }}$; two bushels, $\$ 2.50 ; 10$ bushels, $\$ 12.00$.
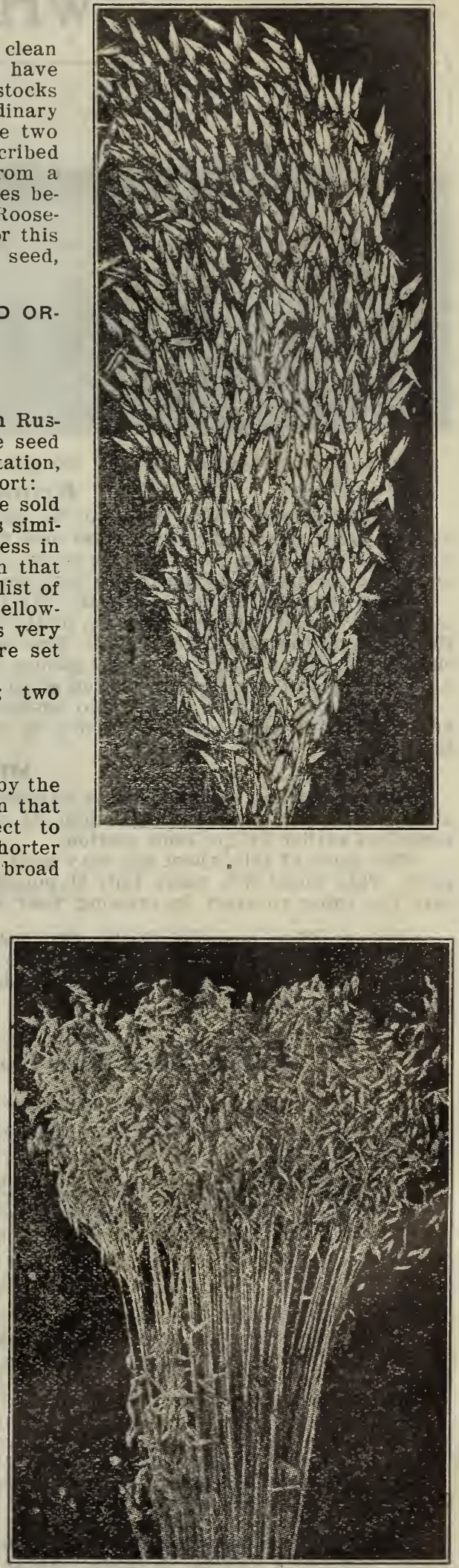


\section{WHEAT $\stackrel{\text { PEDIGREED }}{\text { STOCK }}$}

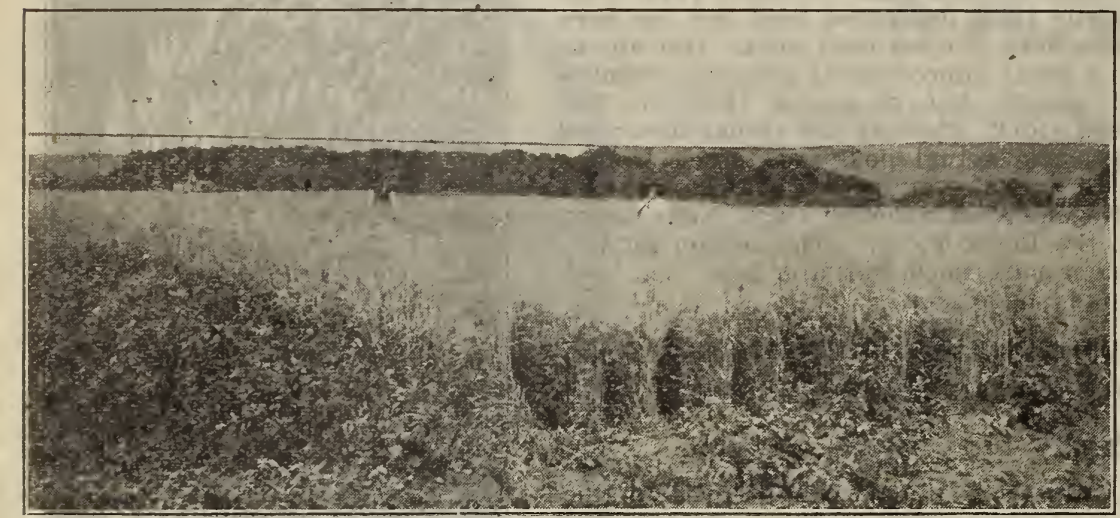

Pedigreed

\section{Stock}

\section{Thoroughly \\ Reliable}

Prof. Shaw selecting our No. 169 Blue Steam Wheat.

\section{Remarks About Our Wheat}

Our Pedigreed Wheat must not be confused with Common Seed Wheat of different varieties. We have selected this seed with a great deal of care and sown it on new land, and consequently it has cost us a great deal of money. The pricos we ask for this wheat show a less margin of profit than any other one thing we handle, owing to the extreme care and expense we go to in preparing the same.

Our Pedigreed Bluestem Wheat. We took for the foundation No. 169 Minnesot? Blue Stem, as it came from the Experimental Station of Minnesota. We have fine stocks of this wheat, sample weighs fully 60 pounds to the measured bushel. The past year, although very dry in this (Barnes) County it yielded close to 20 bushels per acre. Any farmer who wishes to start a seed plot can do no better than to buy a few bushels of our Pedigreed Blue Stem Wheat.

Prices: 10 bushels, $\$ 18.50$; two bushels, $\$ 4.00$; one bushel, $\$ 2.10$; one-fourth bushel 75 cents. Sacks are extra at 25 cents each. We ship in new seamless sacks and they are well worth the money to any farmer.

\section{MINNESOTA No. 169}

This is a wheat the Minnesota Experiment Station put out several years ago and they claim -it yields about twenty-five per cent more than.its parent wheat Haynes' Blue Stem. 'This was a type put out sometime earlier by the same station.

Our stock of this. wheat are very good and we have gone to a great deal of expense to keep them pure. This wheat wilı weigh fully 60 pounds to the measured bushel, a plump, fine berry, and would be just the thing to start in growing your own seed from.

Prices: Ten bushels, $\$ 20.00$; two bushels, $\$ 4.30$; one bushel, $\$ 2.25$; one-fourth bushel, 90 cents. Sacks extra at 25 cents each. We ship in new seamless sacks and they are well worth this money to any farmer.

\section{Macaroni Wheat Direct From Russia}

It is an undoubted fact that Macaroni wheat does not yield as good as when first introduced into this country. The yield is possibly 40 per cent less than when it was first introduced. This has caused a great deal of commotion amongst agricultural experimentors, and upon investigating the matter thoroughly we have come to the conclusion the reason for this was not the fault of the Macaroni wheat, but from the fact that it was the different seed stocks or that Macaroni wheat had become mixed and otherwise spoiled for large yields in this latitude.

Last winter we sent to Russia and obtained at great expense some pure Macaroni wheat from one of the Provinces celebrated for the growing of Macaroni wheat. We had this wheat planted on the heavy clay soils of the Northwest part of the state. The yield was 34 bushels to the acre, whereas the best Blue Stem yield from that same locality was 18 to 20 bushels, therefore we hold that our contention in order to raise the yield on Macaroni it is necessary. to go back to the head for seed and get it absolutely pure. We have only a limited amount of this seed.

Prices: Ten bushels, $\$ 18.50$; two bushels, $\$ 4.00$; one bushel, $\$ 2.10$; one-fourth bushel, 75 cents. Sacks extra at 25 cents each. We ship in new seamless sacks and they are well worth the money to any farmer. Write for prices in large quantities.

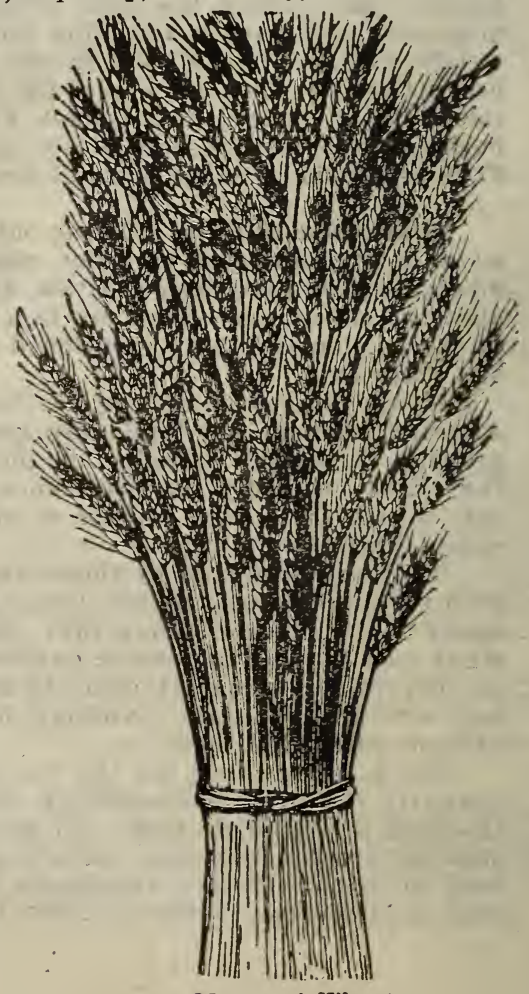




\section{OTHER FIELD SEEDS}

\section{VELVET CHAFF WHEAT.}

We have been very fortunate in securing our stocks of Velvet Chaff wheat from the originator of this wheat. We have taken the same care with this wheat that we have with the other strains and the prospective purchaser should not confuse it with ordinary Velvet Chaff.

We can furnish field run Velvet Chaff wheat very much cheaper than the price quoted here. This price is for extra selected wheat when this wheat first came out it was a very poor milling wheat, and consequently discriminated against by the buyers in the markets but since it has been raised here it has acclimated itself to these conditions and gets more like ordinary wheats. In order to get the increased yields from this wheat it is necessary to get the seed stock as near the parent wheat as possible.

Price. Ten bushels, $\$ 16.00$; two bushels, $\$ 3.50$; one bushel $\$ 1.30$; one-fourth bushel, 50 cents. Sacks extra at 25 cents each. We ship in new seamless sacks and they are well worth the money to any farmer. Write for prices on large quantities.

\section{WINTER WHEAT.}

Culture: By Prof. Thos. Shaw.

Winter wheat will grow in almost any kind of soil possessed of a reasonable amount of plant food. Nearly all the soils of the prairies and also the soils of the bench lands of the west are eminently adapted to its growth. The chlef hazard to the crop if from winter killing when the ground is bare or from being thrown out through the ground heaving by alternations of freezing and thawing in the spring. This however seldom happens on the prairie or bench soils. From the Eastern border of the Red River Valley to the Cascade Mountains, winter wheat should be sown on summer-fallow or drilled in between the rows of a crop of corn or on unplowed stubble land, barley preferred. If sown on breaking, the ground should be broken early and deeply and given much disking and harrowing. It should be sown in the Northwestern states from August 1st to September 1st, according to the distance North. It is best sown deeply, as deep as 3 to 4 inches and on firm ground, with a press drill. Where sown in standing corn a one horse drill is used. The corn stalks when the crop is cut, like the stubbles of grain will hold the snow. This crop properly grown should do well in all the Northwest. The best variety to sow is the Turkey Red, sometimes known as the Alberta Red and the Minnesota Reliable, also, Dakota Golden Chaff. From 6 to 3 pecks should be sown per acre, according to the soil and climate conditions. Under very dry conditions 3 pecks are enough, and increase may be made as the climate becomes more moist and the soil is less well prepared.

\section{TURKEY RED WINTER WHEAT.}

We have, probably, the purest stocks of Turkey Red Winter wheat in existence. Two years ago we got this wheat for our grower and had it planted in Central Montana under dry land conditions. We not. only found it practical, true to type, but a god yielding wheat, and superior from a milling standpoint to the average winter wheat, which has been sold for seed in this locality in the past. Sold in sealed bags only. Price: one-fourth bushel, 75c; one-half bushel, $\$ 1.00$; bushel, $\$ 1.65$; ten bushels, $\$ 1.00$ per bushel. Price subject to change without notice.

\section{PREMOST FLAX NO. 25.}

This flax cannot be too highly recommended. It has been tried out by the best authorities and found to be the best yielding flax known.

This flax was originated at the Minnesota Experimental Station, it is a type by itself and experiments at the Minnesota and also at the North Dakota Stations show that the yield is three to five bushels more per acre than ordinary flax. Prices on application.

\section{CLEAN WESTERN DAKOTA FLAX.}

Owing to the large demand we have hac for clean flax that was raised upon sod, we have put in large stocks of this flax that we know was first crop off from sod. It is very clean and has not been infected by diseased ground whatever. The average sower of flax will readily see that this a great advantage. We are prepared to furnish this flax in bushel lots or car load lots as our customers desire. On this variety write for prices in carload lots. Prices on application.

\section{SPRING RYE}

An excellent feed for all kinds of stock, especially good for hog pasture or sheep feed. We have excellent stocks of Spring Rye, which we quote as follows:

One bushel, $\$ 2.25$; five bushels, $\$ 2.15$ per bushel; ten bushels, $\$ 2.10$ per bushel. This price subject to. change without notice. 


\section{BA RIFY}

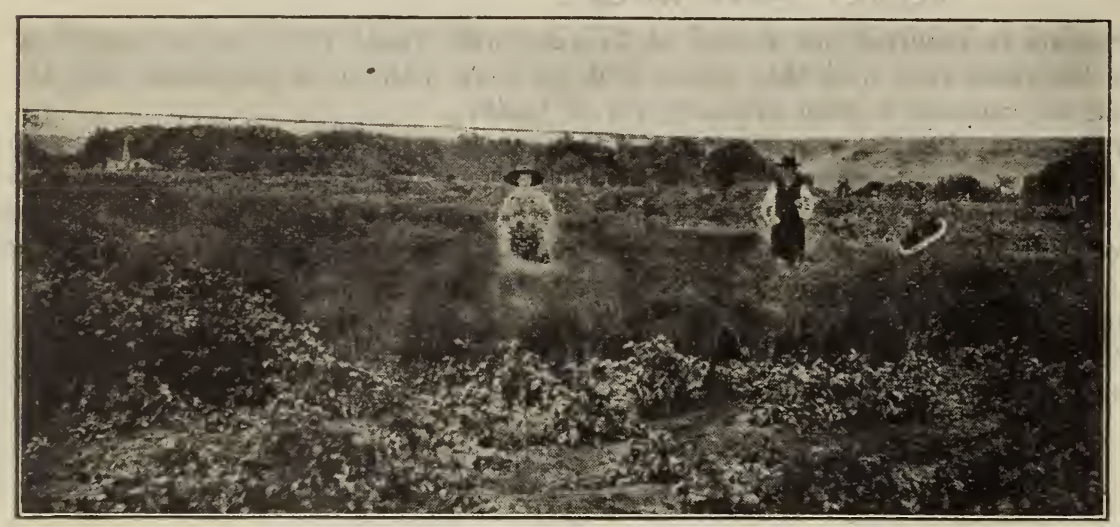

ETERNAL

VIGILANCE

is not only the

PRICE OF LIBERTY

but also the

PRICE OF

GO0D SEED

Prof. Shaw Selcting Some of Our Field Grains.

\section{Mandscheuri Barley}

This grand Barley was introduced from Asia by the Ontario Agricultural College several years ago, and is, beyond doubt, one of the most valuable variet:es ever introduced into this country, greatly outyielding the once justly renowned Manshury Barley. It is an early 6-rowed variety, maturing in 80 to 90 days from time of sowing, and is adapted to all kinds of soil and climate; is very strong strawed, stools well, and bears large and well filled heads of plump grain, which possesses malting qualities of the highest order. Another important factor is its nice and bright color, which will not turn dull and yellow when exposed to rainy weather, as most of the other var-eties do, and on this account it will always be in good demand by the brewers, and will command the highest market price. A good maltir.y Barley always sells for at least 10 to 15 cents more than such as is discolored and which can only be used for feeding purposes. By growing the Mandscheuri, instead of some common variety, one can quite easily gain from $\$ 5$ to $\$ 10$ per acre. Price: Peck 40 cents; bushel, $\$ 1.25$. Sacks extra at 25 cents each.

\section{Success Beardless Barley}

This is a new 6-rowed Barley, and, as the name indicates, without beards, which is the most valuable improvement ever made on barley. It is a vigorous grower, producing strong, short straw and heavy, well filled heads. Its earliness is one of the most important features, as it can be cut and put out of hte way before the wheat and oat crop is harvested. On good land it has produced 80 to 90 bushels per acre in favorable seasons. In regard to soil, it is not particular, as a good crop of Beardless Barley can be raised on land too poor to produce a crop of wheat or oats. It is a first-class malting barley and equally good for feeding stock, therefore always bringing the highest market price. It should not be mistaken for the beardless Hulless Barley, which is described below and which is grown for feeding purposes only. Ever since this grand new Barley was introduced there has been such a demand for it that we were always short in supplying our trade, and we anticipate another great rush for this year. Price: Peck, 50 cents; bushel $\$ 1.60$. Sacks extra at 25 cents each.

\section{Blue Ribbon Barley}

The seed of this variety is now largely used by all the Milwaukee brewers who give it preference over any other variety of barley, paying a liberal premium for it over the price to be realized for other barley's. Its value with the brewers lies in the fact that the percentage of saccharine matter is higher than found in any other variety of barlew. Its popularty with the farmers, lies not only in the fact that it commands a premium and is always salable no matter how weak the market may be, but also for its yielding qualities. The berry is usually very large and solid with rather heavy hull. 'well closed and well filled out. For the guidance of our customers we would state that this barley appears to do best on a rather heavy and preferably rolling soil. The barley has been named the Blue Ribibon as its color undtr the hull and near the tip is distinguished by a bluish tint. Price. Large pkt., 10c, postpaid: one-fourth bushel, 45 cents; bushel, $\$ 1.30$. Sacks extra at 25 cents each.

Trite for special prices on straight or mixed carloads. 


\section{Hulless Barley}

Dakota's Future Feed.

It is Hulless and Beardless.

It's value is inestimable to everyone who feeds stock.

It makes excellent lard and pork.

It is an enormous yielder. Yields well even on poor land.

Weighs 60 lbs. to the measured bushel.

Matures very early.

Last year we procured our seed stock of White Hulless Barley from what we supposed was a reliable source, and the stocks were delivered to us very late in the winter. We found that they were mixed with foreign matter and of course we could not send it out under these conditions. This year we have obtained our stocks of seed from Australia and had it grown on the clay land of Montana and we feel justified in saying that nowhere will our stocks of White Hulless Barley be equaled.

White Hulless Barley is not a malting barley, but no other variety of barley has proved so valuable to the stock raiser. It excells in earliness, yield and quality. While the hulls are sufficient to holt it, they are easily separated in threshing. It is safe to feed to all kinds of stock, as it has no beards. It may be used successfully as a catch crop as it matures easily in from 60 to 90 days. The grain weights from 50 to 60 pounds per measured bushel. It will yield from 40 to 80 bushels per acre. When ground with oats it makes excellent horse feed, or may be fed alone to horses, feeding only one-half the quantity, of oats that would be fed. It has no equal as fattening feed for hogs, and makes nicer meat and lard than corn. It is often grown for hay, being cut just before it rippens and while the straw is green. It is keenly relished by all kinds of stock. The straw is firm and net inclined to lodge.

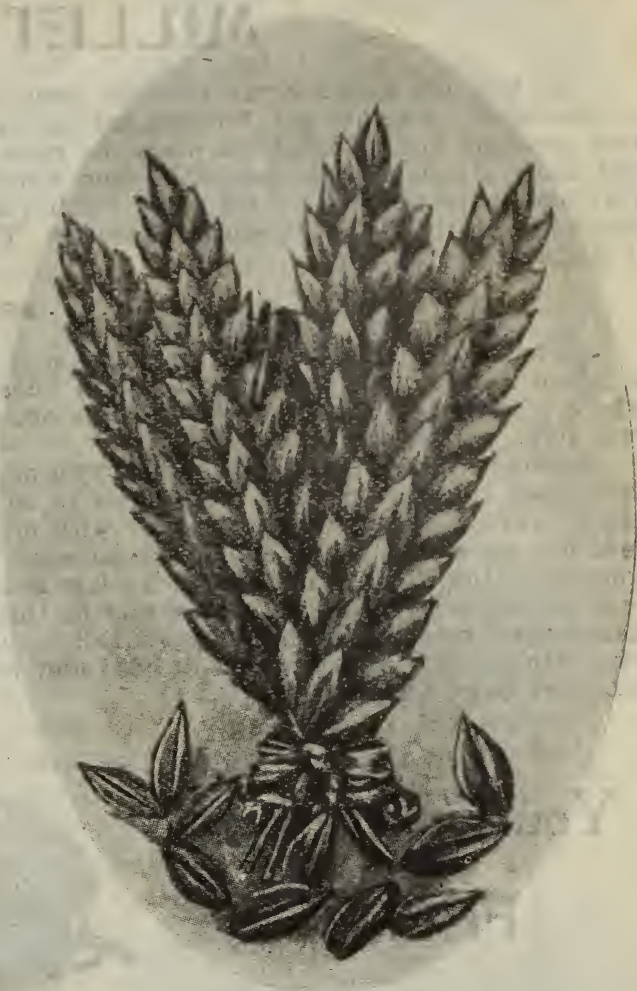

Hulless Barley

Prices: Ten bushels, $\$ 14.50$; two bushels, $\$ 3.0 n$; one bushel, $\$ 1.60$; one-fourth bushel, 50 cents. Sacks extra at 25 cents each. We ship In new seamless sacks and they are worth the money to any farmer.

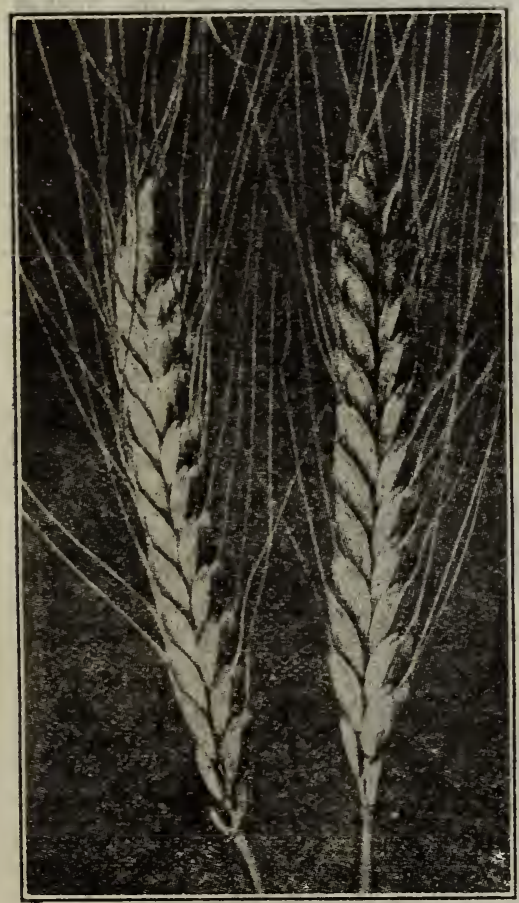

Heads of Speltz.

\section{Speltz}

The most Drought Resistant Cereal in Existance.

Will Produce a Heavy Crop on More Kinds of Soll than any Other Cereal.

Will Not Rust or Smut.

Far Ahead of Barley for all Kinds of Stock.

Ripens Very Early.

A Very Profitable Feeh for the Northwest.

Shes:

If yea have never raised Speltz, be sure to raise some the coming year. It yields enormously, especially in dry years and makes a very profitable crop on any farm where feed is used to any extent whatever. 'It weighs 40 pounds to the bushel.

Prices: Ten bushels $\$ 10.00$; five bushels, $\$ 5.50$; one bushel, $\$ 1.20$; in 50 bushel lots, 90 cents per bushel. Sacks are extra at 25 cents each. We ship in new seamless sacks and they are well worth the money to any farmer.

Northern Seed Company, Valley City, N. D.

Gentlemen: Having received Seed Corn from you last year I wish to say that I am very well pleased with the seed. It will yield better than forty bushels to the acre and is good solid corn. Thanking you for past favors, I remain, Very truly yours.

MURRAY PACK, Bryant, S. D.

Northern Seed Company, Valley City, N. D.

Gientlemen: I was somewhat disappointed by the looks of the Corn I bought from you last spring as it was not very "showy" looking, but after testing it I found it to be geod seed and in the field it showed even better for it did not miss a hill. Wishing you success, I remain,

Yours for business, FERD HAMMERMEISTER, Wahpeton, N. D 


\section{MILLET ALL PRICES SUBJECT TO}

The last dry seascn being very dry many a farmer is not well supplied with feed as far as Millet Hay is concerned. The hot dry June ruined the average crops throughout this country and the feed proposition certainly looks dismal but when the rains in the latter part of July came, it revived the millet fields and many a farmer today has some feed whereas if he had not had in some millet he would have been in very bad shape for feed for his stock. Millet is something that may be planted any time from the 15th of May to the 15th of August wih fair returns. The hay is worth more than timothy hay, ton for ton, unless it might be for horses.

\section{SPECIAL NOTICE}

Owing to the small amount of raillet seed required per acre, (about ore-half bushel of the finer sorts) it is not economy to undertake to plant cheap mill et seed. We get our millet seed from the far South where it rippens before the weeds come on, consequently, it is perfectly free from foul seed. This is a very important item.

Southern Millet Seed will produce two or three times as much millet per acre as INorthern Seed, and then again Northern Seed is more likely to be full of foul weeds. We ask you to be particularly careful to not .. \& fuse the prices given below with prices quoting Cheap Norther Grown Millets. Our millet seed has earned for us an enviable reputation from the fact we always handle the best. There is no other concern in the Northwest that for the last six years has had so many complimentary references on millet seed as our firm. The reason for this is, the head of our concern goes every year to Oklahoma and Kansas and selects our millets personally. In fact we are in touch with several farmers in that locality who ship us their entire output of seed and we pay a high premium for this seed owing to the fact the fields are hand weeded.

\section{You Get the Best}
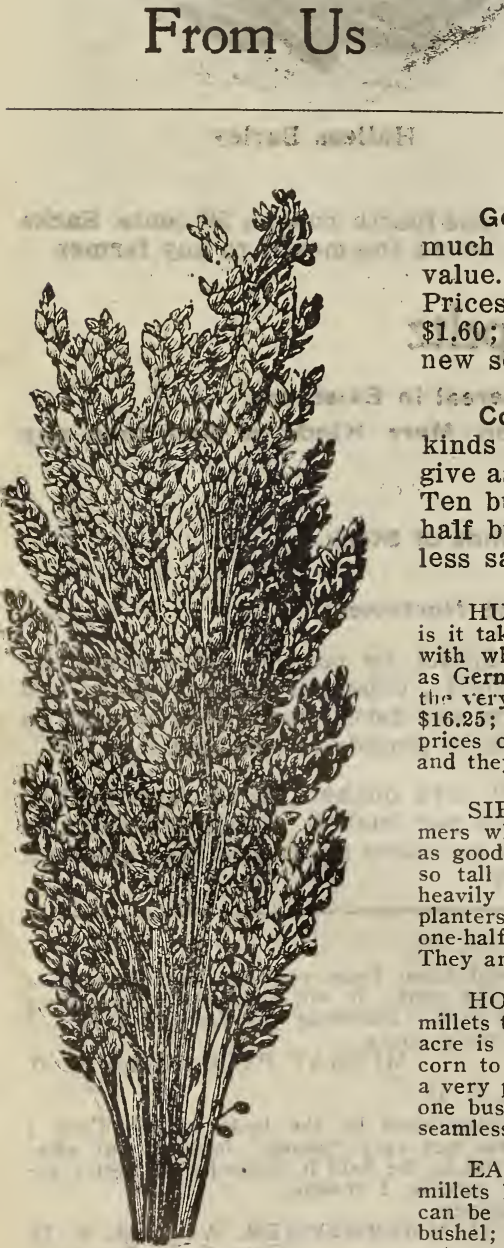

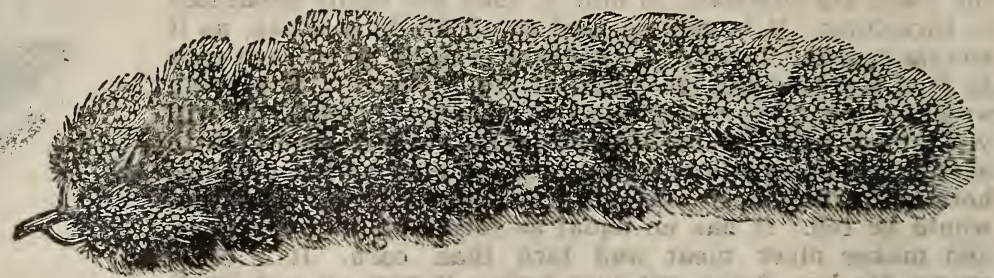

Head of Golden Millet

German or Golden Millet-This millet is a very desirable millet in as much as it yields a larger-amount of hay, very sweet and of great feeding value. On rich soils this millet will produce from four to five tons per acre. Prices: Ten bushels, $\$ 15: 00$; two and one-half bushels, $\$ 3.75$; one bushel, $\$ 1.60$; one-half bushel, 90 cents. Sacks extra at 25 cents each. We ship in new seamless sacks. They are well worth the money of any farmer.

Common German or Golden Millet-This is somewhat mixed nsth other kinds of millet. We can furnish this millet ait co not remominete to give as good ersults âs the Southern Grown gerwán or Goldenk Millef Prtces: Ten bushels, $\$ 14.00$; two and one-half bưshels, $\$ 3.50$; one bushel, $\$ 1.50$; 0 onehalf bushel, 85 cents. Sacks are extra at 25 cents each. We $\$$ hip in seam. less sacks and they are well worth the money to any farmer.

HUNGARIAN MILLET-The advantage of Hungarian Millet over German or Goiden is it takes a shorter season to mature it and owing to this fact it is a good millet to fill in with when other crops fail to come or are washed out, etc. Hungarian is not so coarse as German or Golden but still yields heavily, 34 tons per acré of hay is often harvested, of the very best quality and is greedily eaten by all kinds of stock and swine. Price: Ten bushels $\$ 16.25$; five bushels, $\$ 8.25$; two and one-half bushels, $\$ 4.25$; one bushel, $\$ 1.75$. Write for prices on larger quantities. Sacks extra at 25 cents each. We ship in new seamless sacks and they are worth the money to any farmer.

SIBERIAN MILEET-Our stocks of Siberian Millet are very choice. We have customers who have planted our Siberian Millet the last six years and who claim that, it gives as good or a better yield than the German or Golden Millet. Siberian Millet does not grow so tall as the German or Golden and the straw is somewhat finer but as it stools very heavily it produces a great many leaves and for this reason is liked very much among planters. Price: Ten bushels, $\$ 15.00$; two and one-half ubshels. $\$ 3.75$; one bushel, $\$ 1.60$; one-half bushel, 90 cents. Sacks extra at 25 cents each. We ship in new seamless sacks. They are well worth the money to any farmer.

HOG MILLET-The proper name for this millet is Broom Corn. It is one of the few millets that can be planted in the Northwest and profitably raised for the seed. 'The yield per acre is from 50 to 75 bushels according to conditions and the feed when ground is equal to corn to fatten cattle and hogs.- This millet is fairly early, maturing in from 50 to 60 days; a very profitable crop. Prices: Ten bushels, $\$ 1.40$ per bushel; five bushels, $\$ 1.45$ per bushel; one bushel, $\$ 1.50$; one-half bushel, 85 cents. Sacks extra at 25 cents each. We ship in new seamless sacks and they are well worth the money to any farmer.

EARLY FORTUNE MILLET-The earliest Nillet known aird one of the best yielding millets known especially for the seed. This millet readily heads in from 25 to 30 days. It can be fed to all kinds of stock without danger whatever. Prices: Ten bushels at $\$ 1.40$ per bushel; five bushels, $\$ 1.45$ per bushel; one bushel, $\$ 1.50$; one-half bushel. 85 cents. Sacks extra at 25 cents each. We ship in new Seamless bags and they are well worth the money to any farmer. 


\section{Japanese Barnyard Millet}

(Billion Dollar Grass)=-Grows from four to seven feet tall, but is not harsh or woody, as other grasses and is one of the most profitable and valuable seed crops. We have grown this splendid Millet for years, and have been so careful in the selection and improvement of stock seed that our strain is acknowledged to be the best in existence. In some sections of the country $i$ tis known as Barnyard Millet, while in other parts of the country it has been erroneously introduced under the name of "Billion Dollar Grass." In spite of these names it is such a good thing that it has come to stay, and will live long in the public favor under its proper name, Japanese Millet. In this latitude we usually sow from May 10 th to 20th. Sown at these dates it will make an excellent soiling crop, giving two cutings-about mid-July and late August. We have frequently had this Millet attain a height of one-half to seven feet, and so heavy that no binder could handle it. It yields 50 to 70 bushels seed per acre and three to five tons hay. Sow the seed broadcast at the rate of twenty to twenty-five pounds to the acre, or in drills twelve to eighteen inches apart, using ten tó fifteen pounds per acre. Postpaid, pound 20 cents; three pounds 50 cents. By express or freight, not prepaid, one-eighth bushel 40 cents; one fourth bushel, 65 cents; one-hal $\mathrm{f}$ bushel, $\$ 1.10$; bushel, (36 pounds) $\$ 1.95$; two bushels, $\$ 3.80$; ten bushels or more at $\$ 1.85$ per bushel.

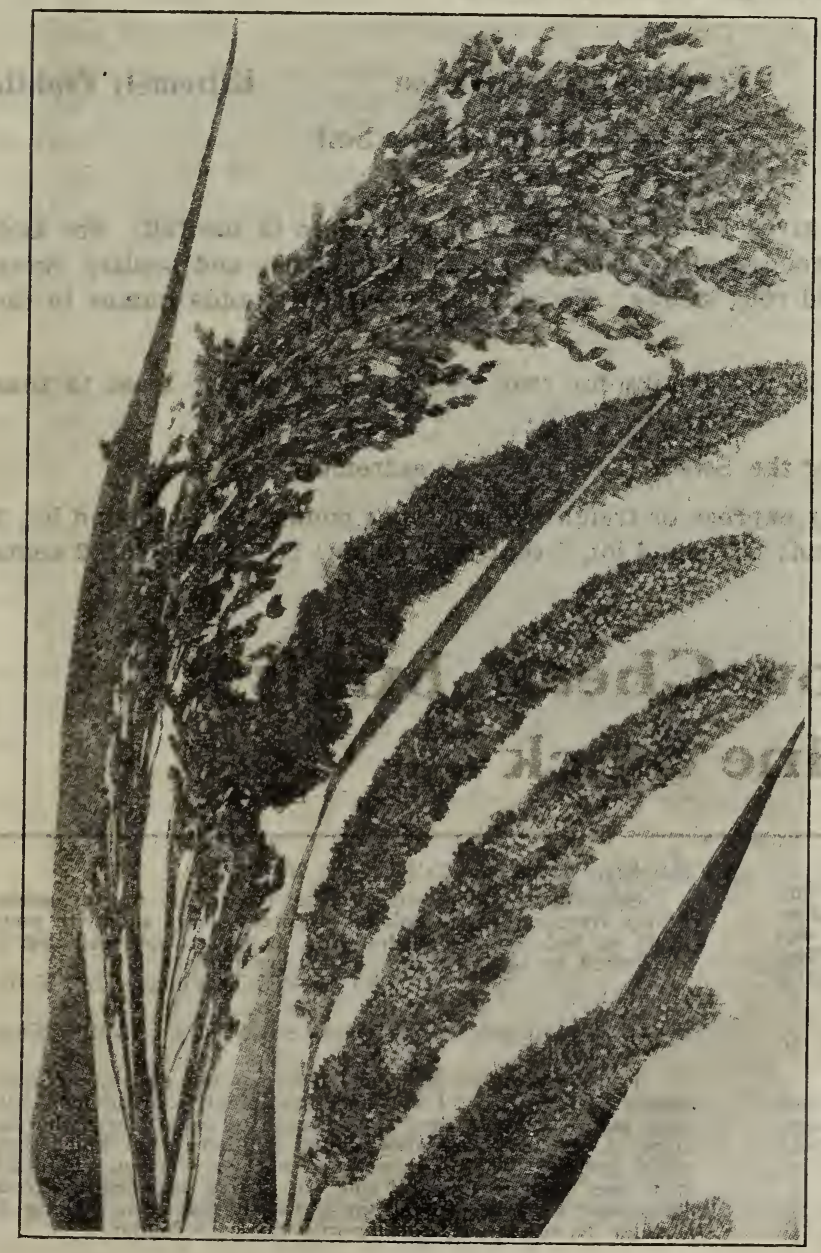

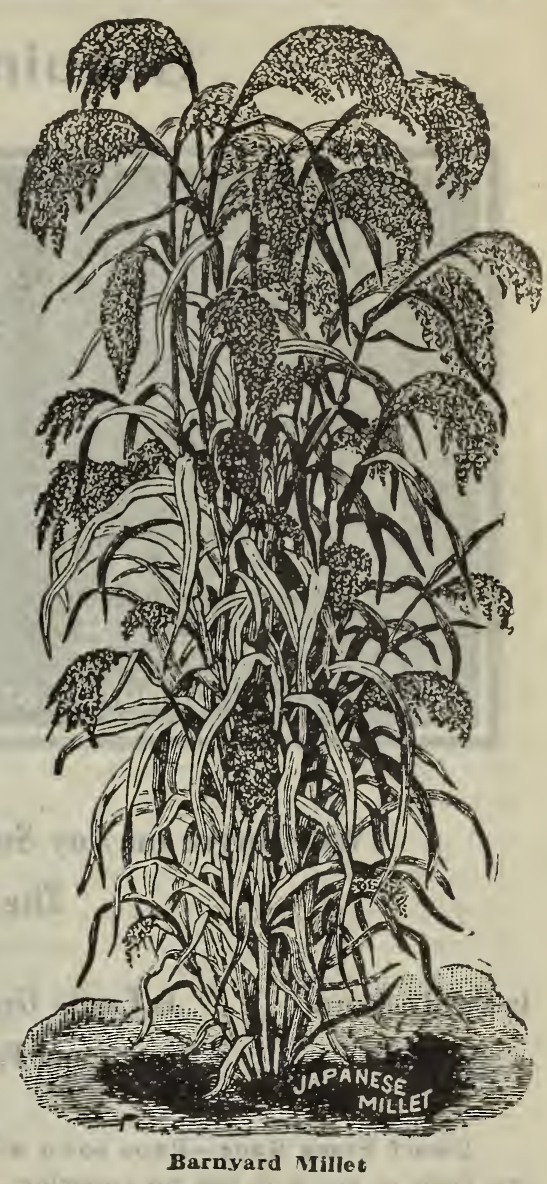

Kursk Millet

Kursk Millet-This grand new millet was put out from the United States Agr. cultural Department about four years ago. We obtained some of the seed and have been experimenting with it ever since. We find that on clean rich ground this millet will yield enormously, sometimes as high as 75 bushels per acre. The seed is a deep mahogany brown, but when ground looks like yellow corn meal. Feeding value is equal to corn, but it is rather coarse for hay, however, many use it for hay and report favorably. It is a great millet to plant on sod and we would recommend it to new comers in the country rather than the other millets to use on sod. Late in summer it yields an enormous amount of feed and will be found by all growers to be very pro. fitable. It requires about three-fourths bushel per acre. Prices. Ten bushels, $\$ 17.50$; two and one-half bushels, $\$ 4.55$; on $\ominus$ bushel, $\$ 1.85$; one-half bushel, 95 cents.

Try Northern Grown Seeds for Northern Conditions 


\section{Genuine Dwarf Essex Rape}

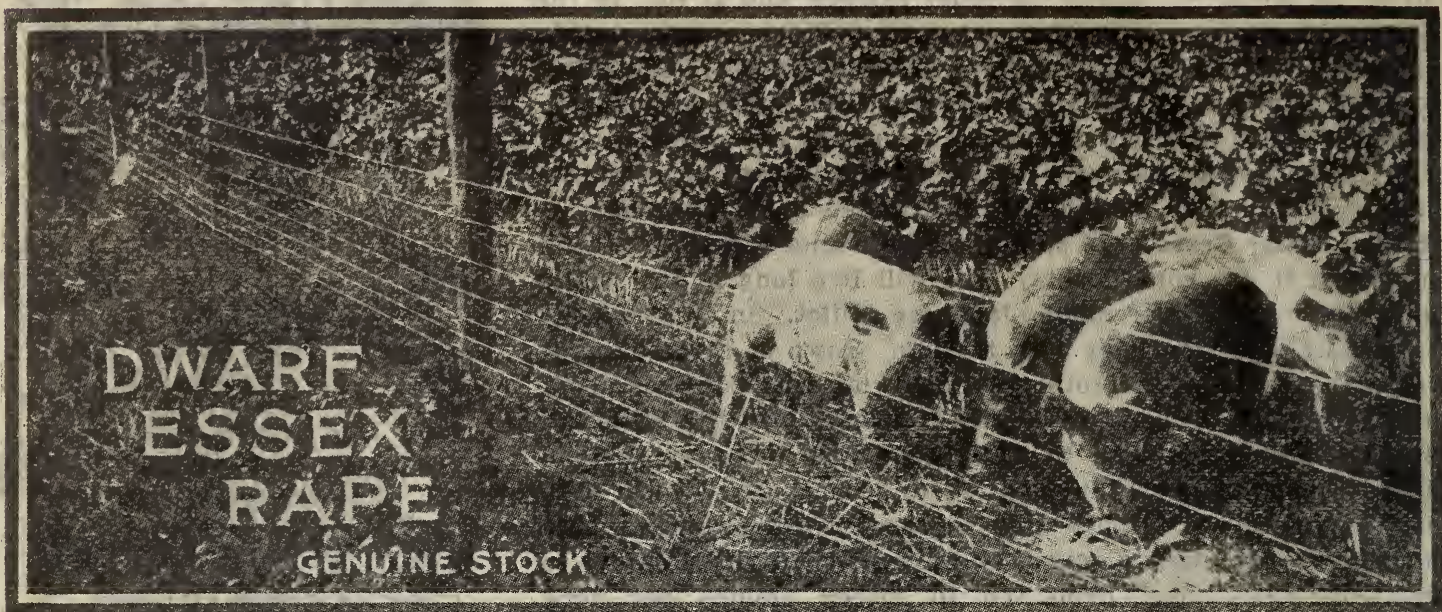

Will Thrive on Any Soil

Unexcelled for Nutritiousness

\section{The Great Forage Plant for Stork}

Is Easily Sown

\author{
Is Easily Grown \\ Great Land Fertilizer
}

Requires No Cultivation

Adds Humus to the Soil

Dwarf Essex Rape-Rape sown with grain gives feed for all kinds of stock late in the fall. For adding flesh to stock it has no superior. Makes good pasture crop for cattle, hogs, sheep and poultry. Sown in orchards it makes a good protection to avoid root. killing. To plow under green it adds humus to the soil.

One acre of rape will furnish pasture for 10 to 20 hogs for two months, supplying at least 12 tons of green feed.

In appearance, rape resembles the leaves of the Swede Turnip and is extremely prolific.

Prices: One Pound postpaid, 20 cents. By express or freight 10 cents per pound; in ten pound lot, 9 cents per pound; 25 pound lot, 8 cents per pound; 50 pound lot, 7 cents per pound; 100 pounds, $61-2$ cents per pound.

\section{Rape--Not How Cheap, but is it Genuine Stock?}

Northern Seed Co., Valley Lity, N, D.

Dear Sirs: I tried some of your seed potatoes on my farms. I feel well repaid. I had the best crop of potatoes since I have rented my farm. My renter said the seed was responsible for more than half the extra yield. The Flint Corn I got from you I sent to one farm in Canada. This is the first corn we have ever matured in Canada. Yours truly,

T. L. BEISEICKER, Wells Co., N. D.

Northern Seed Co., Valley City, N. D.

Gentlemen: In years past I have used a great deal your field seeds on my farms. I am very much pleased with the way you have taken care of my seed wants. You may be sure that we are one of your steady customers.

REGAN LAND COMPANY

$$
\begin{array}{r}
\text { J. Austin Regan, Pres. } \\
\text { Wells Co., N. D. }
\end{array}
$$

Northern Seed Co., Valley City, N. D.

Gentlemen: We cannot speak too highly of our seeds. I have lived in North Dakota seventeen years and with your seeds we had the best garden yet. It pays to get seed that is acclimated to this country. Yours truly,

ALBERT T. REID, Williams Co., N. D.

Mr. E. S. DeLancey, Mgr., Northern Seed Co., Valley City, N. D.

I took your advice and planted some of your Northwestern Dent Corn. I am glad that I took your advice. My corn matured and I have a good crop of sound corn whereas some of my neighbors who planted Southern seed which they could get somewhat cheaper, did not get a crop. I found your seed nearly all grew and was strong and healthy from thle start. I also found the corn all got ripe, making it possible to cut it successfully with my corn binder. 


\section{Field Peas}

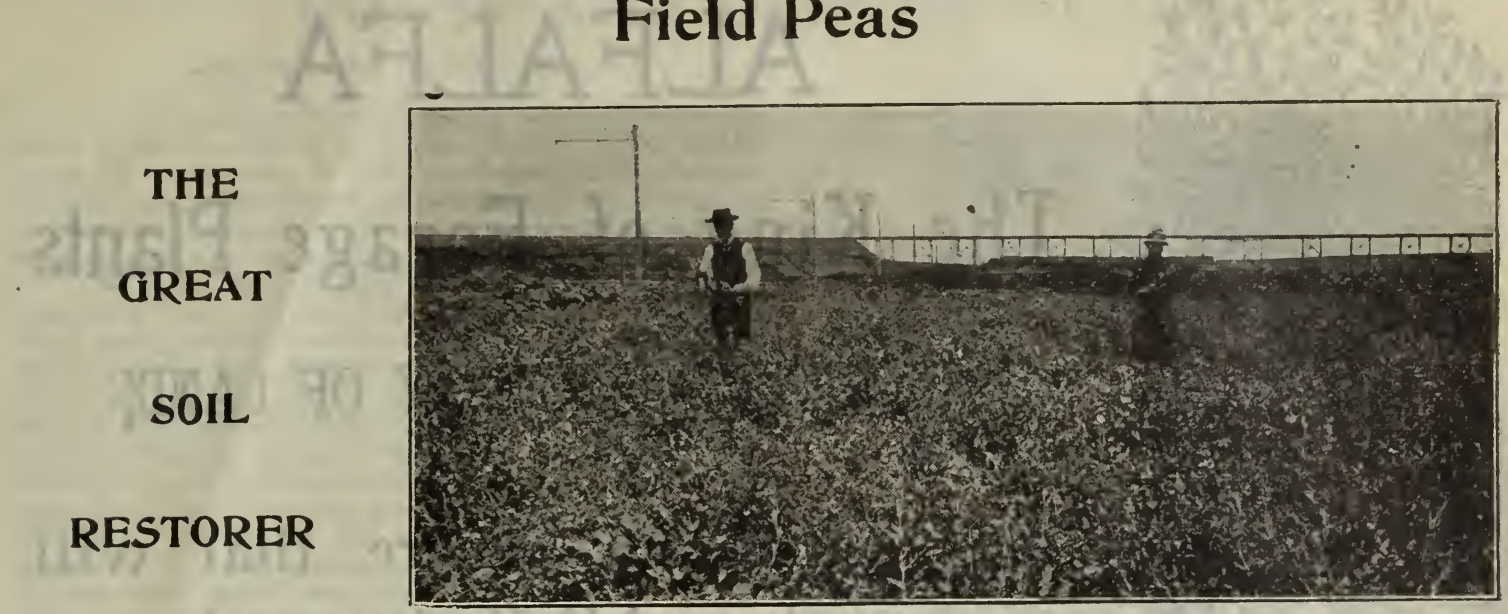

Prof. Shaw and Helper Selecting Peas.

Culture (By Prof. Thos. Shaw): The Field Pea, usually spoken of as the Canadian Field Pea, will grow well over the entire Northwest if properly sown, and like the clover it enriches the soil while it is growing. It prefers a loam soil well impregnated with clay. Light sandy soils produce too little straw and slough soil too much. Two methods of growing are adopted. By the first, the seed is buried as deeply in fall plowed land as the drill will bury it. By the second, the seed is drilled in near the surface, on unplowed land and the land is then plowed to the depth of say five inches. In both instances the land is well harrowed while the peas are, say two or more inches short of the surface of the ground. About two bushels of seed per acre are sown of the small variety and from two and one-half to three bushels of the Marrowfat varieties. There is not much difference in the yields of those that are white, blue, gree or gray. The crop may be harvested with the horse rake, but the work is very much better done by using the pea harvester attachment on the field mower. It may also be harvested by swine where it has grown.

\section{CANADIAN FIELD PEAS}

\section{The Great Soil Restorer.}

No wheat farm is complete without a liberal acreage of field peas. The nitrogen gathering quality in this plant is great, consequently, preparing the land better than anything else for subsequent crops of wheat.

On farms that have had continual grain croping field peas should take an important part. They are not only one of the greatest feeds, when matured for stock but also furnish exceptionally good pasture for sheep, cattle and swine. When desired to use field peas for pasture one bushel of peas, one-half bushel of oats, one-half bushel of barley should be sown together.

Besides an immense amount of high grade feed raised per acre, the restoring of the soil of a pea crop is beneficial. No forage plant restores the soil so rapidly or thoroughly as field peas. When a stand of alfalfa is especially desired, a crop of field peas prior to the sowing of alfalfa is the best preparation possible. Prices: One bushel, $\$ 2.50 ; 10$ bushel lot, $\$ 2.30$. Sold in sealed bags only.

\section{Buckwheat}

Buckwheat is something there is not nearly enough of planted in the Northwest. There is nothing that will distroy weeds like buckwheat. Take a plot that is very weedy and sow buckwheat, giving it thorough tillage and it will produce a luxuriant growth by the middle of August at wich time plow the buckwheat under. This will not only increase the vield of wheat or other crop the following year, but will practically exterminate the weeds. The cost of seed is so inexpensive that it does not make it too expensive to follow this system; it is being followed profitably by many of the best farmers of our state and should be adopted by more of them. Prices: Ten bushels, $\$ 12.50 ; 2$ bushels, $\$ 2.70 ; 1$ bushel, $\$ 1.45$; one-fourth bushel, 50 cents. Sacks are extra at 25 cents each. We ship in new seamless bags and they are well worth the money to any farmer. 


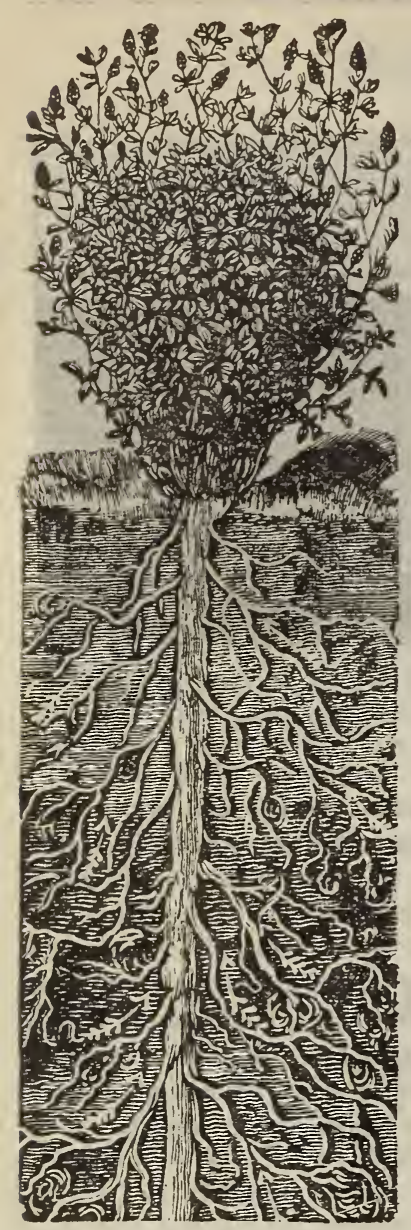

Alfalfa or Lucerne

Will this root resist drought? Yes.

\section{ALFALFA}

\section{The King of Forage Plants} [INCREASES FERTILITY OF LAND!

\section{Any Land any where that will produce Alfalfa is worth}

\section{$\$ 100.00$ per Acre}

\section{Many fields are growing in North Dakota. Your land will grow it} if you try.

NOTE:-See Prof. Churchill's letter on cover.

Culture: By Prof. Thos. Shaw.

Alfalfa will grow best on bottom lands that are sandy in texture and with water not far distant from the surface, and on uplands with a clay subsoil that is reasonably porus. The ground on which it is sown should first be made rich with farmyard manure. This crop is best sown on land summer fallowed the previous year or that has grown a crop of potatoes, corn or field roots. The ground should be kept well stirred near the surface until well on in May or early June. The seed may be sown by hand, but it better buried with a drill to the depth of 1 to 2 inches. From 12 to 15 pounds of seed are sown per acre. When the plants are from 8 to 10 inches high, they are frequently cut off, weeds and plants, with the mower set high and the cut proportion left on the ground as a mulch. The yield is improved by judicious disking every spring. The crop should last for several years when once established. If the soil needs inoculating; this may be done in the same way as clover is inoculated. See page 36.

We have procured our stocks of alfalfa in Montana. Our Turkestan alfalfa we have procured from the old country. We handle nothing but the best grades of alfalfa, unless the cheaper grades are asked for. Sold in sealed bags only.

Prices: Fancy Montana Grown Alfalfa 30 pounds and less, 24 cents per pound; 60 pounds, up to 200, pounds, 22 cents per pound; 200 pounds and over, 21 cents per pound; 1000 pounds and over, $20 \mathrm{c}$ per pound. This price subject to ${ }^{\circ}$ change without notice.

We guarantee our best grades of alfalfa to come under the pure seed law of North Dakota, according to the provisions of our guarantee on inside page of front cover.

Many people think that alfalfa can only be grown under irrigation. Herewith we show rou a picture of alfalfa root taken from life. This root will convince any one that alfalfa is the greatest dry land forage crop in existence. The root goes down to moisture like a tree. Last year in June, when everything was practically dried up in North Dakota, the only green fields to be seen were the small patches of alfalfa scattered throughout this (Barnes) county. This should convince anyone that alfalfa can be successfully grown here. 


\section{GRASS AND CLOVER SEEDS}

\section{GRADES AND GUARANTEE.}

In all cases with grass seeds we guarantee our best grades according to the guarantee on the inside page of front cover of this catalogue. The cheaper grades we prefer to sell on sample and do not guarantee them as above.. Our best grades of grass and clover seed are "Home Grown" seed.

Owing to the fact that in older countries, in the east and south a great deal of the land is becoming very weedy, extra fine clover and timothy seed is very hard to get. Seed ordered from houses in that locality is very apt to contain some of the noxious weeds native to an older settled country than ours. Growing our seed, as we do, in North Dakota and Northern Minnesota, on comparatively new land, we get seed not only adapted to sowing under northern conditions, but also seed that is free from dangerous weeds as possible. It is our aim to supply only "Home Grown" timothy and clover seed and these samples will always be sent upon application, unless the poorer grades are desired.

By "Home Grown" Timothy and Clover Seed, we mean seed grown north of the south line of North Dakota. The very choicest seed obtainable, recleaned and made as perfect as brains and money can make it. Remember our "Home Grown" brand of timothy and clover is equal or superior (and in comparing prices, we ask you to remember this) to any of the so-called special brands of other seed houses i. e. "Globe," "Sterling," "Farmers," "Hawkeye" brands' etc.

e Ware very proud of the samples of our "Home Grown" brand of seeds and strive vigorously to maintain their quality. It is with. such seeds as our "Home Grown" Clover and Timothy that we expect to maintain the trade of the best farmers of the Northwest. We can furnish you the grades, Fancy, Choice, and Prime, but recommend for purity, our"Home Grown" brand.

Our "Home Grown" brand of Medium Red Clover is guaranteed to fulfill the provision of the Pure Seed Law of North Dakota. Price: "Home "Grown" Brand $\$ 13.00$ per bushel; Fancy, $\$ 12.00$ per bushel; Choice, $\$ 10.50$ per bushel; Fair, $\$ 8.00$ per bushel.

IMPORTANT NOTICE-Our "Home Grown" Brand of Grass Seed is guaranteed to fulfill the provis. ions of the Pure Seed Law of North Dakota, but the other brands, Fancy, Choice and Fair are not so guaranteed and we prefer to sell them under sample.

Culture (By Prof. Thos. Shaw): These clovers do best on a clay loam soil with a reasonable porus clay subsoil, but they will also grow well on a sandy loam soil underlaid with clay. They also do best where there is a reasomable amount of moisture. The common red produces two cuttings as a rule in one season of which the second is frequently grown for seed. The mammoth produces but one cutting whether for hay or for seed. It is much coarser and stronger than the common red and should, therefore, be grown on less fertile soils. Both should be sown in the early spring and preferably with a nurse crop of barley or rye. If sown, with winter rye the seed should be covered with the harrow. The seed may be sown by hand with a wheelbarrow seeder or other kind of a hand seeder or by an attachment to the grain drill, which allows the seed to fall before the grain tubes. One stroke of the harrow follows the drill. Sown alone, about 10 to 12 pounds are required. When sown with timothy for hay about five to six pounds of each will suffice. In many instances the land must first be inoculated before it will grow good clover. Inoculation may be brought about by sowing one to two pounds of seed per acre with grain for a few successive years or scattering about 200 pounds of earth from a good field of clover over each acre of the land where clover is to be sown. Common red clover should be cut early, where the second crop is to produce seed.

\section{ALSIKE OR SWEDISH CLOVER}

One of the hardiest perennials known, does not winter kill, suitable for hay or pasture, produces an excellent quality of hay when sown with timothy or red clover. Prices same as medium Red Clover.

\section{WHITE CLOVER}

Valuable for pasture mixture, also suitable for lawns, very hardy and adapted to all kinds of soil, of running trailing growth, valued highly for honey bees. Sold under guarantee on inside page of front cover. Only best grade handled. Price 30 cents per pound. Price subject to change without notice.

\section{RED TOP}

Red Top is a grass particularly adapted to moist land and on rich moist soil will yield large quantities of fine hay. Great portions of the Northwest are not adapted to the growing of Red Top, but a few localities, on the edge of sloughs, etc, can be sown to Red Top very advantageously. It thrives very well under the above conditions and makes an excellent pasture providing it is pastured short. On land bordering on wet places, in pastures, we would recommend it, but on the ordinary prairies of this state, we would not. Blue Grass, Timothy or Bromus Inermus being much better. Only the best grade handled, consequently guaranteed according to our Guarantee on inside page of front cover. Price: Hulled seed 25 cents per pound. 


\section{GRASS SEED-=Continued}

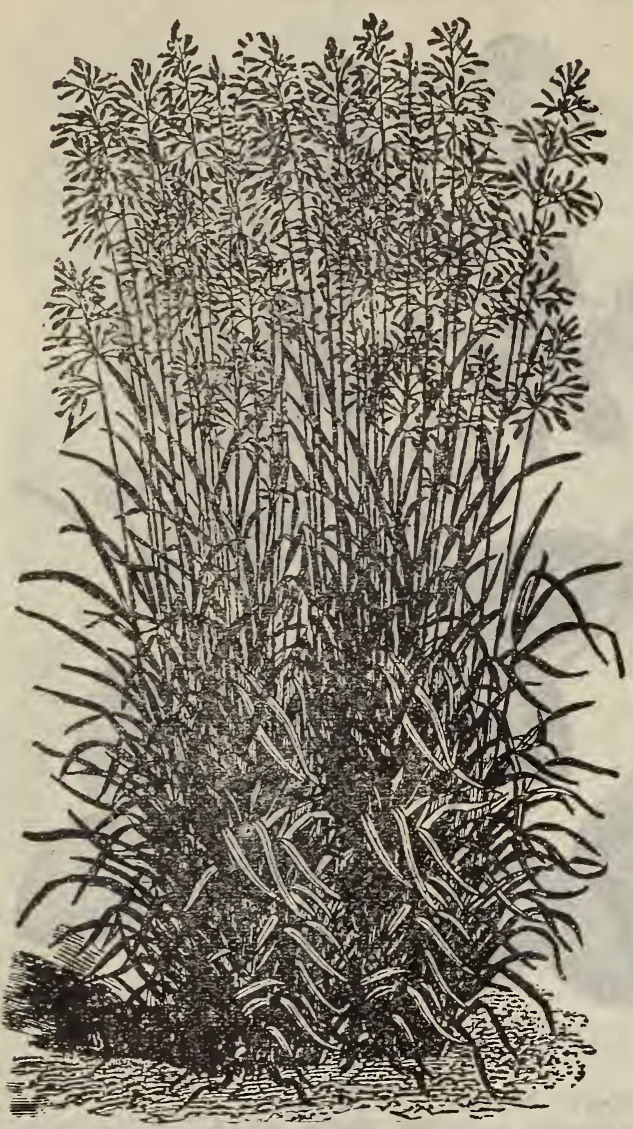

KENTUCKY BLUE GRRASS.

Kentucky Blue Grass is fast coming into favor in the Northern country. It is one of the greatest pasture grasses. Owing to the fact that the grass seed trust controls the out put of the crop this year, the price is almost prohibitive. Price: $221 / 2$ c per pound; $\$ 22.00$ per Cwt. Sacks are extra at 25 cents. We ship in new seamless sacks and they are well worth the money to any farmer.

Northern Seed Co., Valley City, N. D.

Gentlemen: We planted some of your Regenerated Swedish Select Oats last year with a good deal of misgiving, but when the crop came off we were agreeably surprised. The straw was not only strong er than our ordinary oats but the yield was nearly one-third more. The yield on two acres of your oats was 110 bushels per acre.

ALFRED G. CODDING, Valley Co., Mont.

Northern Seed Co., Valley City, N. D.

Dear Sirs: It is with pleasure we recommend your Seed House for the reason the shipment of seeds we received far surpassed anything of the kind we ever had. The oats were perfectly clean and the product of the same was enough to give us entire new seed oats for the coming year. OLAF JOHNSON, Big Stone Co., Minn.

Northern Seed Co., Valley City, N. D.

Gentlemen: I was well pleased with the Alfalfa seed I purchased from you in 1908. I have a good stand. I am no longer doubtful about alfalfa since using your seed. Yours truly,

JAMES MORGAN, Ward County, N. D.

Northern Seed Co., Valley City, N. D.

Gentlemen: All the seeds we bought from you are doing fine. The oats and alfalfa are going to make a very good stand.

L. J. DEDRICK, Pembina Co., N. D.

Northern Seed Company, Valley City, N. D.

Gentlemen: All the seeds sent me by the Northern Seed Company were first class. The Alfalfa Seed in particular is a good stand. ALBERT RANKY, Fessenden, N. D.

\section{Brome Grass}

\section{THE GREAT PASTURE GRASS}

\section{BROMUS INERMUS.}

TIMOTHY

Timothy is another grass that is almost certain to make a good crop in North Dakota. Owing to the fact that Grass Seed Trust has got hold of the timothy seed this we are compelled to ask a high price for same. Price: ew seamless sacks and they are well worth the farmer.

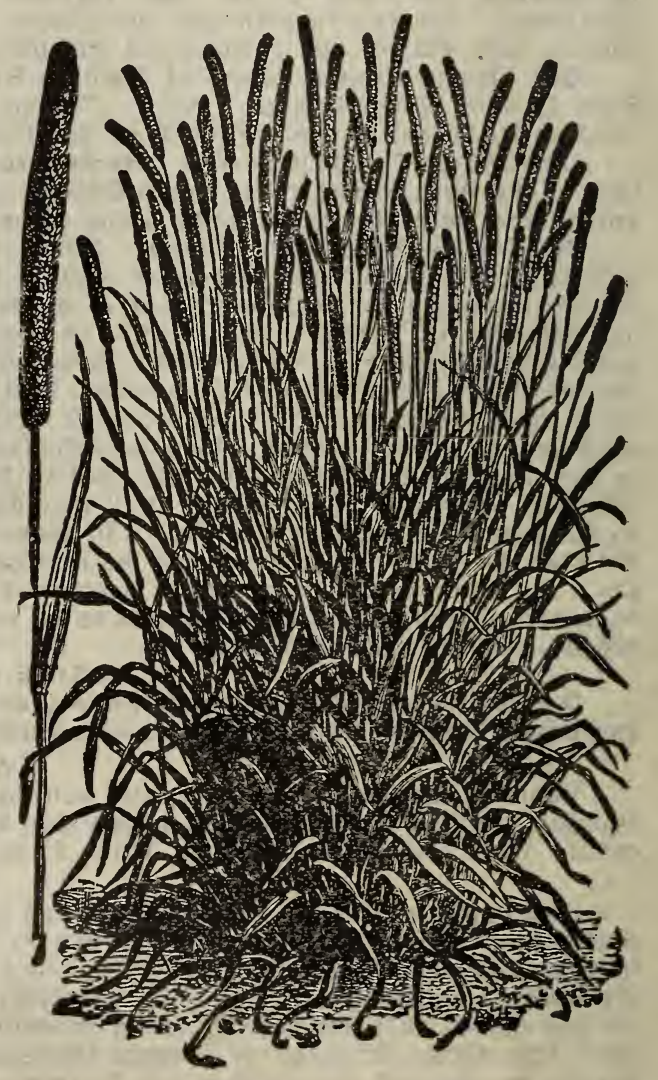




\section{TO OUR CUSTOMERS}

To Our Customers:---

We wish to announce that we have sold our nursery interest to The Northwest Nursery Company of this city. All orders and inquiries relative to trees, shrubs and fruits should be sent to them They assurie our obligations in replacing stock-write direct to them. We cheerfully and heartily recommend them to our customers, knowing they will receive honest treatment and the best and hardiest stock that money can buy.

Signed: NORTHERN SEED CO.

$\mathbf{N}$ ORTH DAKOTA is a prairie state, but with a rich vegetable soil, weil adapted to tree growing. Our prairies grow beautiful trees, if hardy acclimated trees are planted. 'But much discouragement has come to our planters because of tender stock shipped in, that is poorly suited to the rigors of our drying winds and frosts. Further our soil is a loose rich loam, just like that on your own.farm, unlike either the clay or sand found in other states, it developes the roots wanted for Dakota soil. Much of the stock shipped here, though otherwise hardy, gets a bad set back through change of soil.

The Northwest Nursery was estabiished to fill a much needed and long felt want. It has splendid grounds on the open prairies near Valley City, and is raising trees, fruits and shrubs by the millioir. Its purpose is to supply North J)akota, South Dakota, Montana and the Canadian Northwest with trees and fruits that are not only hardy, but adapted to our soil, frosts and drying winds,-in other words, trees that are acclimated. The splendid business that the Company is receiving proves that the people are making a demand for such a Nursery. They want a Nursery that is conducted by men of character, run on an honorable basis and one that can furnish hardy stock that can grow here.

Now we want you to know what kind of stock we grow-we are determined to prove to you what we say about our hardy prairie grown stock. We have decided to give you some bargains, just to advertise. Write us at once for our Bargain Price List. We will cut prices almost in two this spring-just to show you our stock, and secure you for our regular customer. Ask for "Bargain Advertising List."

Here are a few points which we ask you to think of carefully; a few reasons why we deserve your business: $1-\mathrm{We}$ are in the heart of the Northwest Prairies. 2-We raise stock that will grow here. 3-Stock that will grow here will grow on your farm. 4-We guarantee our stock and mean it. 5-We are where you can call and see us. 6-We are here to stay, and to do business.

When in Valley City, call and visit our grounds, and be convinced of the superiority of our stock.

\section{The Northwest Nursery Company}

Valley City, North Dakota 


\section{INDEX}

\section{VEGETABLE SEEDS}

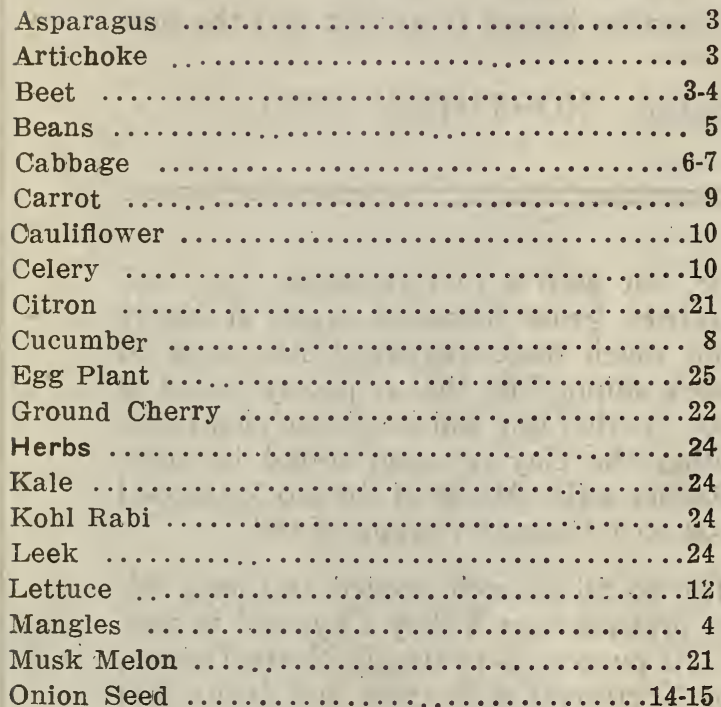

Onion Sets $\ldots \ldots \ldots \ldots \ldots \ldots \ldots \ldots \ldots \ldots . \ldots \ldots$

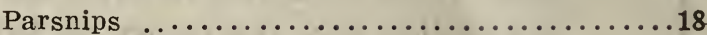

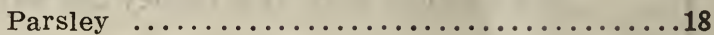

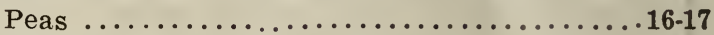

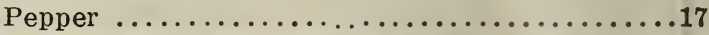

Potatoes ........................41-44

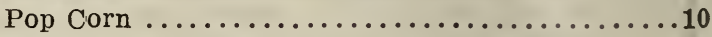

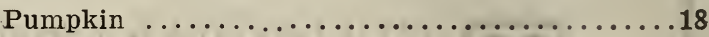

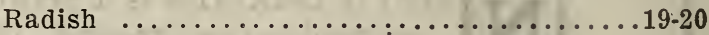

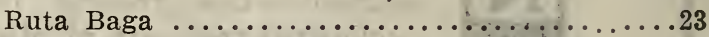

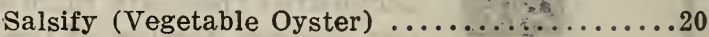

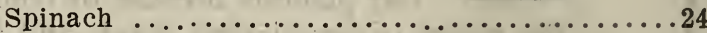

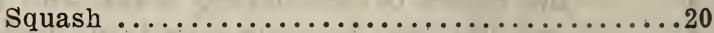

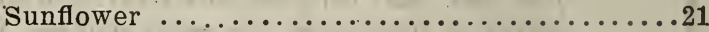

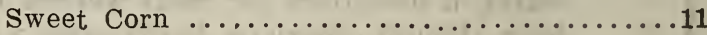

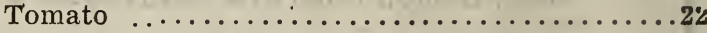

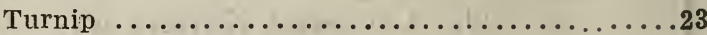

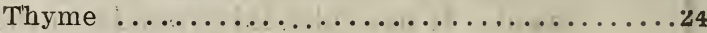

Water Melon ...........................

\section{FLOWER SEEDS}

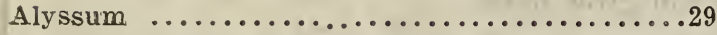

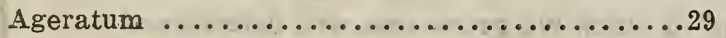

Balsom (Lady's Slipper) ..................29

Candytuft .........................29

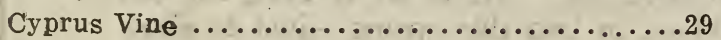

Four O'Clock ......................29

For-get-me-not $\ldots \ldots \ldots \ldots \ldots \ldots \ldots \ldots \ldots \ldots \ldots$

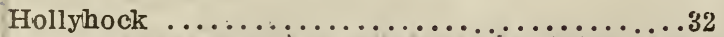

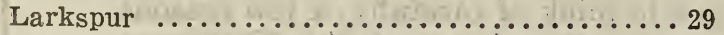

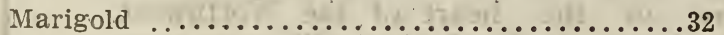

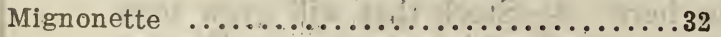

Morning Glory . . . . . . . . . . . . . 29

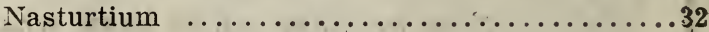

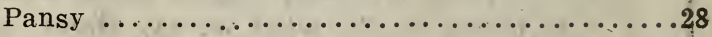

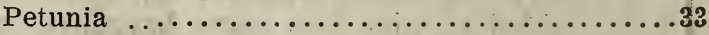

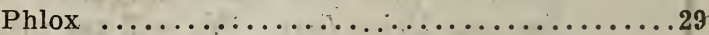

Pink (Dianthus) ................... 38

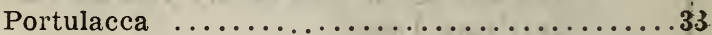

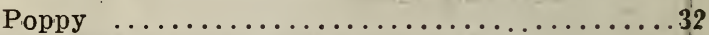

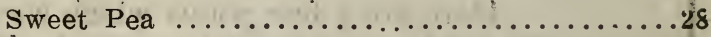

Verbena $\ldots \ldots \ldots \ldots \ldots \ldots \ldots \ldots \ldots \ldots \ldots \ldots . \ldots \ldots$

Zinna ......................29

\section{FIELD AND GRASS SEEDS}

Alfalfa ........................... 58

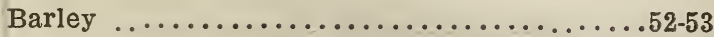

Blue Grass ........................60

Brome Grass ........................60

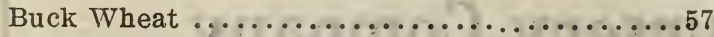

Corn ............................... 340

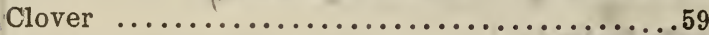

Fertilizer $\ldots \ldots \ldots \ldots \ldots \ldots \ldots \ldots \ldots \ldots \ldots . \ldots \ldots$

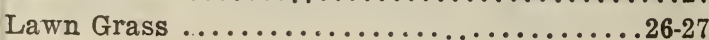

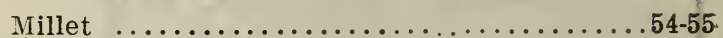

Oats .......................... $45-49$

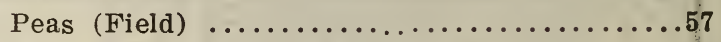

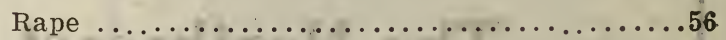

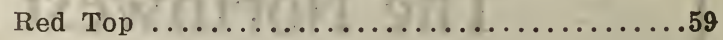

Speltz ....................... 53

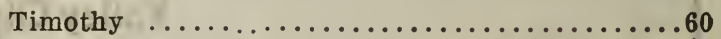

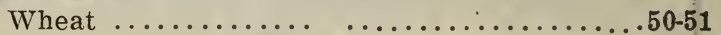




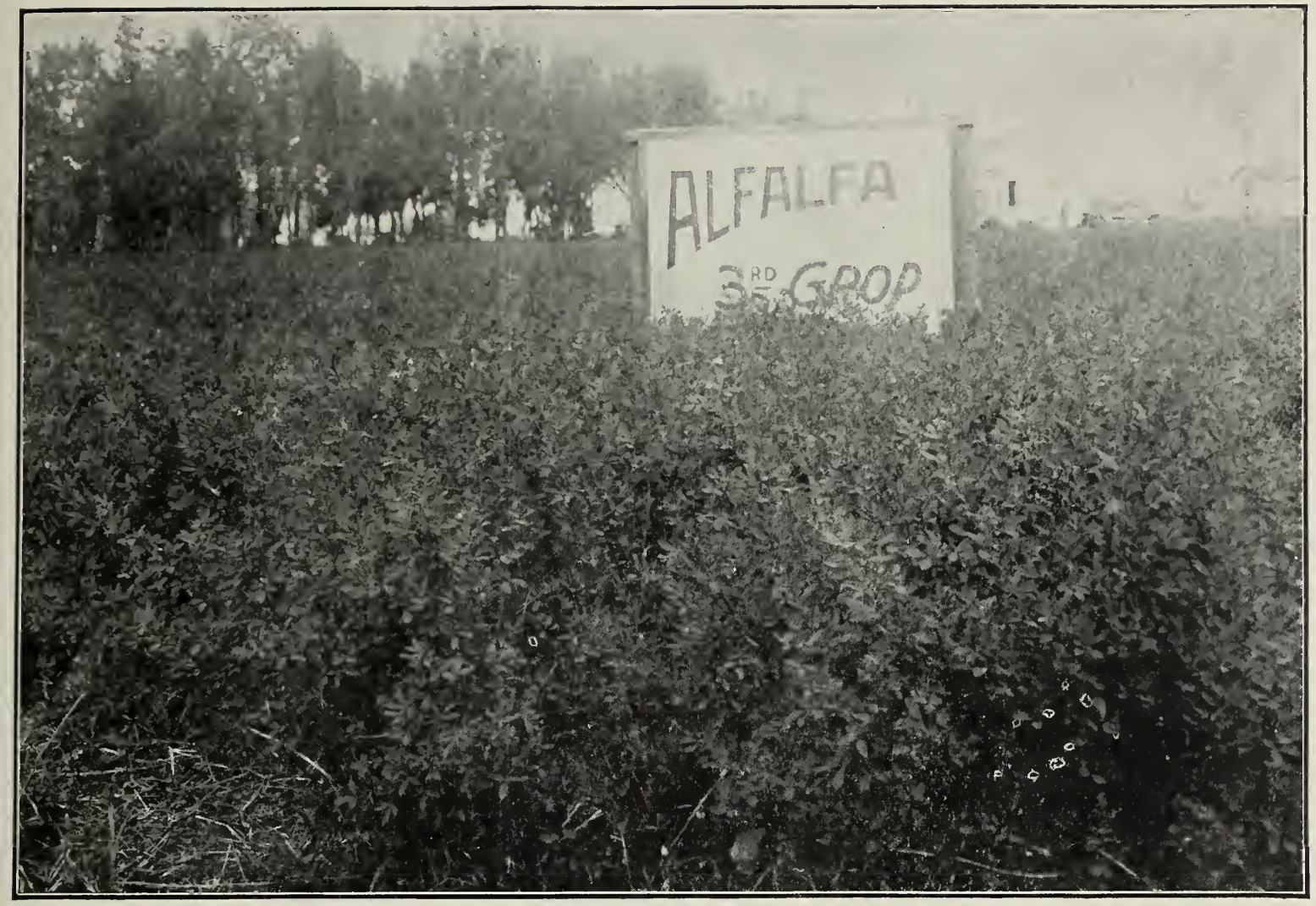

J, H, WORST, L. L. D. Prest.

W. A, YODER. SEC'Y

\section{NORTH DAKOTA AGRICULTURAL COLLEGE \\ AGRICULTURAL COLLEGE NORTH DAKOTA}

Mrr. E. S. DeLancey, Valley City, N. D.

Dear Sir:-Alfalfa cannot be too strongly endorsed for any part of North Dakota, outside of the Red River Valley. There are scme local areas, however, where alfalfa may not succeed, but these are small and rather unimportant. In the Red River Valley, medium red clover is to be preferred, except on strictly stock farms.

On account of its great drouth resistance and high feeding value, alfalfa will produce satisfactory amounts of forage where other plants fail. For this reason, every farmer should give alfalfa a thoro trial, especially where they find it difficult to produce winter wheat in abundance.

For cattle or sheep feed, alfalfa is far superior to any other hay that can be grown. It may also be fed to horses, but the ration of both hay and grain must be reduced from the usual amount fed. The alfalfa takes the place of part of the grain feed. It will be best also to feed it only once or at the most twice each day.

The following points should be given careful consideration by those who have not yet grown the cron :

I. Alfalfa may be grown in most parts of North Dakota when given the proper conditions.

2. Use only Grimm, Turkestan or H. Iontana Seed.

3. Seed without a nurse crop in the spring of the year at about the time that barley is usually seeded.

4. The ground should be well prepared before seeding. Newly brokenl ground should not be used.

5. Use only the best seed and seed about I5 pounds per acre.

6. During the first year cut often enough to keep down the weeds and to prevent the leaves from rusting too badly. Cut if t'20 leaves turn yellow.

7. After the first year cut when about 5 percent of the plants are in blossom.

8. Usually it is best to cut only two crops each year but sometimes three may be secured.

9. Do not cut or pasture late in the fall or during the winter.

Io. Manure is very beneficial at any time, but more especially the first year, when applied to the land before the alfalfa is sorvin.

II. Inoculation is usually necessary. Dirt from an old alfalfa field strewn upon the land is the best method of transferring the germs, but do not use the soil from diseased ground. Manures reduce the necessity of inoculation.

12. Commercial cultures are unreliable.

T3. When reasonably used alfalfa improves until it gets to be five or six years old. It will grow a great uany years on the same land. If the stand gets thin, the alfalfa should be disced early in the spring and more seed put on the thin patches. It should then be harrowed and a coating of nanure applied if possible. The disc harrow should be set so that it will not cut the roots off.

14. Good drainage either natural or artificial is essential for the su cess of alfalfa.

15. An old potato field makes one of the best places on which to start the first field.
I would strongly advise starting in a small way. There is no question but what this valuable crop can be grown as small fields are seen in all parts of the state.

Yours truly,

O. O. CHURCHIL,

Asst. Prof. of Agronomy. 



\section{NORTHERN SEED CO.}

Growers of

Home Grown Seeds

Largest growers of seed in the Northwest

Valley City, N. Dak. 
The best seed at reasonable prices

A satisfied customer is our delight
QUALITY is our

Our

unsurpassed

capital, equipment

and experience will be

used in filling your orders watchword 
WE ARE ALSO

LARGE HANDLERS OF

Northwestern Dent CoRn

Montana Alfalfa and

PEDIGREED

OATS AND Wheat

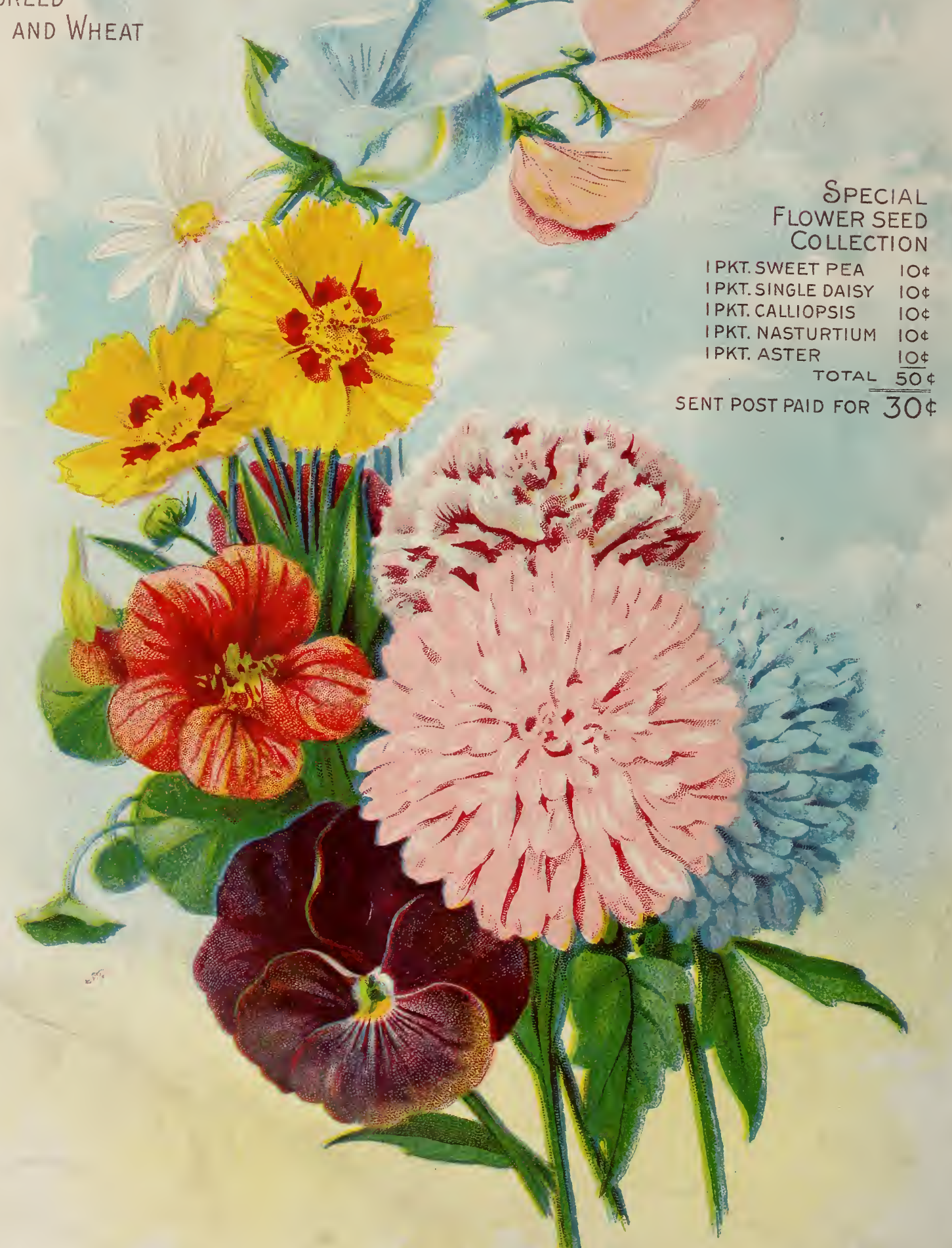

Northern SEED COMPANy

LARGEST GROWERS OF SEEDS IN THE NORTHWEST.

VALLEY CITY, N.D. 